\title{
UP AGAINST IT IN NIGERIA BY LANGA LANGA
}




,

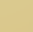




\section{UP AGAINST IT IN NIGERIA}





\section{UP AGAINST IT IN NIGERIA}

w"

LANGA LANGA

WITH 47 ILLUSTRATIONS

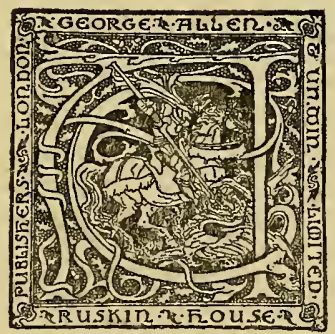

LONDON: GEORGE ALLEN \& UNWIN LTD. RUSKIN HOUSE, 4O MUSEUM STREET, W.C. I 
D $T$

515

$\mathrm{H}_{6} \mathrm{X}$

1922

AFA

First published in 1922

(All rights reserved) 


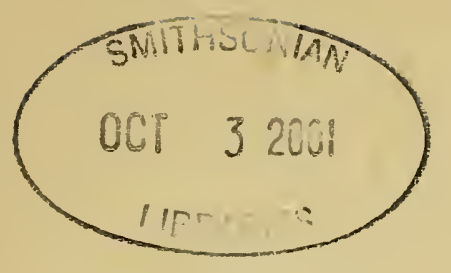

To those who have allowed me to pillage their albums for photographs, let me herewith record my gratitude. To my fellow exiles generally in the Outposts, who have made life possible by that indispensable possession, a sense of humour, and to those of them who have passed out of man's sight in particular,

I DEDICATE THESE MEMOIRS 



\section{PREFACE}

THis book does not purport to be a text-book on Nigeria: still less does it lay claim to any of the literary virtues. Of its very nature it could not, an' it would, command a large reading public. Let there be no misconception about that. It is not even meticulous in its accuracy, being written from memory - a West African memory at that-and unassisted by referenda.

Chiefly for my own amusement, partly inspired by the time-honoured cliché at the "Scotch Club": "if only one took the trouble to write these things down, what amusing reading they would make!" I set myself to jot down my experiences of ten years -it seemed a pity that they should all "go West," for they cover most parts of the Nigerian compass.

In doing so I found myself gradually writing what Boswell or Lander would have called a journal, but what I prefer to describe as a "small-chop" diary-that is to say, a collection of incidents, in more or less chronological order, written, as they would have been told, at the witching hour of small-chop, with scarce a camouflage of persons or localities. In these reminiscences questions of Administration have been left severely alone. 
"But this is all very ordinary stuff which might have happened to anyone!" it may be exclaimed. So much the better. It will then convey, I hope, a reasonable picture of the life of the average Political Officer in its essential features in this country as it was, is, and, in spite of the Railway and Political Memoranda, ever shall be. From it the newcomer may pick up a wrinkle or two between the lines: while the "old bird" may look backwards, and take it, as it is meant, not unkindly.

I shall probably be accused of "coming the old coaster" in my allusions to "those days," and "that time"; but it must be remembered that men and things die and change out here with remarkable rapidity, and that 1918 is as far removed from 1908 in Nigeria as 1908 is from 1838 in the civilized world. Nobody gets more irritable than I do with the prosy gentlemen who refer to the events of "nought four" and "nought six" and so on, as if they were speaking of some landmark in the Dark Ages, or an old vintage. And yet how many of those cheery bush-whackers we knew so recently as nought anything are alive to-day! Not too many-certainly not 40 per cent. of the characters mentioned in this bookand those who are, if we may believe the West African Pocket-book, are so solely by virtue of the drinks they have not, and the quinine they have taken-in my own case some 21,000 grains!

LANGA LANGA.

Nigeria, 1921. 


\section{CONTENTS}

Preface .

CHAPTER

I. BAUCHI . $\quad . \quad$. $\quad$. $\quad$. 15

II. BAUCHI (continued) . . . 24

III. BAUchI (continued) . $\quad$. 39

IV. BaUchI (continued) . $\quad$. $\quad$. 53

V. Naraguta $\quad . \quad+\quad . \quad . \quad .66$

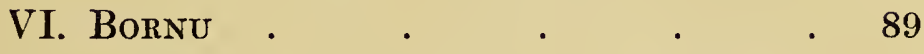

VII. Bornu (continued) . $\quad$. 107

VIII. BoRnu (continued) . $\quad$. $\quad$. 121

IX. HorS D'CEUVRES VARIÉS . . 151

X. The $F_{A L A B A} \quad \cdot \quad$. $\quad$. $\quad$. 168

XI. Yola and Ilorin $\quad . \quad$. 186

XII. ILORIN $\quad . \quad \cdot \quad \cdot \quad \cdot 212$ 


\section{GONTENTS}

Appendix A. "Suli Yola"

Appendix B. Appreciation of the late

$$
\text { W. B. Thomson } \quad \text {. } 239
$$

Appendix C. Apprectation of the late

P. A. Benton $\quad$. 242

Appendix D. Sketch Map of Nigeria, showing Principal Routes Travelled . . Facing p. 244 


\section{ILLUSTRATIONS}

POIING UP THE RIVER BENUE .

FACING PAGE

(S. H. P. Vereler)

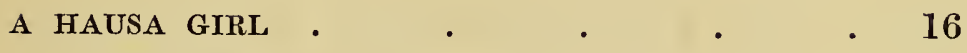

(太. $\nabla$. Elphinstone)

"THE GENERAL"

(W. P. Hewby)

"PETER" IN ENGLAND . . . . $\quad 32$

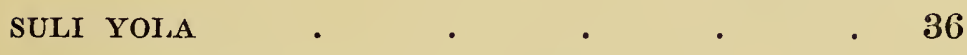

(M. C. Greene)

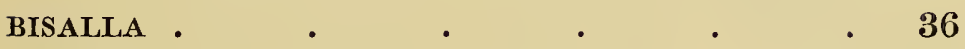

POLLARD LOADING UP THE "MENAGERIE" . 42

SOME TROPHIES • $\quad$. $\quad$ - $\quad$. $\quad$ - 42

MORE TROPHIES . $\quad . \quad$. $\quad$. $\quad$. 64

W. B. THOMSON • $\quad$. $\quad$ - $\quad$ - $\quad$. 94

GEORGE SECCOMBE AND TRAP • . . 94

(P. de Putron)

THE CEMETERY, MAIDUGURI • $\quad$ • $\quad 98$

(W. P. Hewby) 
MEMORIAL TABLET TO "THE GENERAL"

FAOING PAGE (1)

W. P. HEWBY, C.M.G.

100

THE SHEHU OF BORNU.

- 100

(P. de Putron)

A "FARIN GINDI"

(P. de Putron)

BUDUMA CANOES ON LAKE CHAD

108

(P. de Putron)

A KANURI WOMAN

(K. V. Elphinstone)

A LAKE CHAD POLO-CLUB GROUP

- 118

(P. de Putron)

MY (LATER DE P.'S) TRAP

118

(P. de Putron)

"PICCIN"

THE START FROM GEIDAM FOR GUJBA

. 124

IVORIES AND FOOT OF BIG ELEPHANT .

- 138

MELBOURNE INMAN AND "IVORIES" OF ROGUE ELEPHANT!

138

THE OSTRICH FARM

- 142

(P. de Putron)

DISTRICT OFFICER'S HOUSE, MAIDUGURI .

- 142

(P. de Putron) 


\section{ILLUSTRATIONS}

THE SUBMARINE .

TAKING TO 'THE BOATS • $\quad . \quad$. $\quad . \quad 168$

NO. 6 BOAT DIVING FROM THE DAVITS. . 170

NO. 1 BOAT IN TROUBLE $\quad$. $\quad . \quad 170$

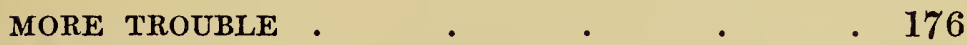

THE STEAM-DRIFTER EILEEN EMMA . . 176

THE CREW OF THE EILEEN EMMA • . 176

(The above seven photos by courtesy of the Daily Mirror)

NIGER IDOLS

(D. Crocombe)

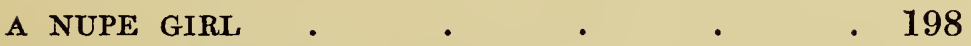

(K. V. Elphinstone)

JEBBA BRIDGE BEFORE COMPLETION

. $\mathbf{1 9 8}$

(S. M. Grier)

THE GUARD OF HONOUR.

200

(R. Sutherland)

ARRIVAL OF HIS EXCELLENCY'S TRAIN .

. 200

(R. Sutherland)

HIS EXCELLENCY INSPECTING RELICS OF THE $\begin{array}{llllll}D A Y S P R I N G & . & & & & \end{array}$

(R. Sutherland)

JUJU ROCK

(R. Sutherland) 
TAME REEDBUCK AT ILORIN . • 204

JEBBA BRIDGE COMPLETED . . . 204 (R. Sutherland)

SMALL-POX JUJU WORSHIPPERS UNDER ARREST 224 (A. H. Discombe)

TRIAL OF THE DELINQUENTS • • 224 (A. H. Discombe)

PUBLIC DESTRUCTION BY FIRE OF SMALL-POX FETISHES . (A. H. Discombe)

"PANSY" AND "ADAM" • • . . 226 (K. V. Elphinstone)

SERGEANT-MAJOR GARUBA, IIORIN POI.ICF $\quad$ • 226 (S. W. Walker) 


\section{CHAPTER I}

\section{BAUCHI}

Probably nobody has ever left the bosom of his family more reluctantly and with less desire for "travel" than I did on Christmas Day, 1908. There was no dinner served on the restaurant train from Euston; and the porter at Lime Street, when he heard that West Africa was my destination, said "God 'elp you!"

I, with my spaniel "Peggy," was apparently the sole occupant of the North-Western Hotel that Christmas night, and as a special privilege she was allowed to share my bedroom. We were driven on Boxing Day by a stale-drunk cabman through a funereal Liverpool fog to the Wharf, and sailed on the Dakar (Captain Lawson) the same afternoon. At about the same moment a not un-remote relative of mine was paying the penalty of his recent adoption as Parliamentary candidate by kicking off a football, in a similar drizzle, in some purlieu of Croydon. I remember wondering which of us felt the brighter.

There were only sixteen first-class passengers on board, and the voyage, but for a furious tossing in the Bay of Biscay, was uneventful. Stone, ${ }^{1}$ a subaltern with whom I afterwards travelled

1 Now Brigadier-General. 
as far as Ibi, was the only other officer on board bound for Northern Nigeria. As there were no electric fans in those days, the cabins after Sierra Leone became not unlike ovens, in which one was gently fried. We made Forcados on the 12th of January, and it was my luck that this should be the last steamer to stand off the Bar, and tranship her passengers and freights on to the branch boat. All subsequent boats passed over the Bar into Forcados harbour. On this occasion we lay off in a mist, while the branch boat hunted for us, to the melancholy accompaniment of the bell-buoy on the Bar. We were then lowered in mammie chairs into surf-boats, and paddled, wet and dejected, to the branch boat, which in turn transferred us to the river stern-wheeler, Sarota, in almost pitch darkness at Burutu.

The lights were not working, and our chopboxes being in the hold, we had to go to bed empty but for a small tot of brandy, very kindly provided by a Roman Catholic missionary, who had come on board. These Fathers are noted for their hospitality, and their Mission is the most, if not the only, practical one in.West Africa. The misery of the newly arrived exile at Burutu is a byword-and I will not enlarge on the dismal subject. It is from Burutu that some drunkards have dated their original fall. I had my share of misery, what with the attentions of the Customs, who relentlessly tore from one duty on cases of liquor, which turned out afterwards to have been broken, or broached, to vanishing point, the 


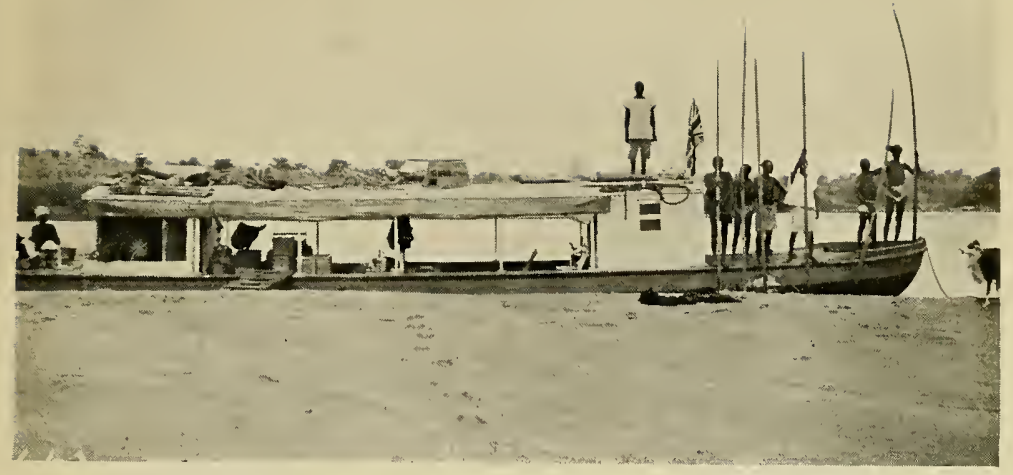

POLING UP THE RIVER BENUE.

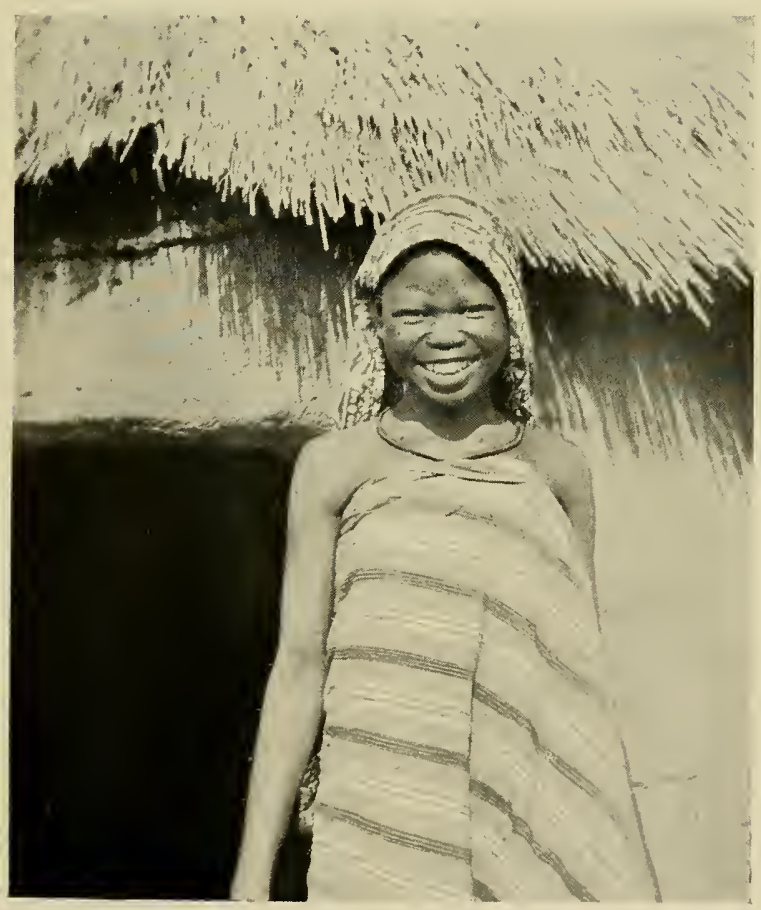

A HAUSA GIRL. 

inability to find anything one wanted, and of course the usual difficulty with "boys."

In this connection coming events did indeed cast their shadow before them when a German trader, who was travelling to Onitsha, said to me deprecatingly: "Vy vorry apout your poys? I alvays bromise my poy von bound on arrival at Onidsha, and ven I gets there I kick him out vidout nothings." A scrap of paper, in fact.

Stone, by the way, handed me over one of his boys, "Yaro," 1 who has been with me, off and on, as boy, cook, and finally courier, ever since.

When we had managed to dig a few provisions, and odds and ends, out of the hold, we had a comparatively peaceful and comfortable voyage of six days, thanks largely to the kindness of Stone, without whom I should have been lost, for I was horribly green (witness my endeavours to fit a filter-candle into a sparklet-syphon)-as are most poor devils on their first arrival.

Never did I make a bigger error than in supposing that Lokoja would be the end of my troubles, and that I should there be met and instructed in my new path of life. Far from it. Not a soul met me, nobody knew anything about me, nor did anyone apparently care. It being Sunday, I was strongly advised not to disturb the "Cant. Mag." (I vaguely wondered whether this had any connection with Mag. Sulph.), as he was having a siesta, and was a liverish gentleman withal. He roas, and his liver was not the only portion of him that was unduly swollen. Fortu-

1 Since dead. 
nately Stone was good enough to get me made an hon. member of the W.A.F.F. ${ }^{1}$ Mess. I spent ten days in the Beach Rest-house at Lokoja, going for my meals to the Mess, where I met, among others, Colonel Mackenzie ("Festive Mac"), in command, and, besides many others who have since answered the call, Coghan, a friend and brother officer of my brother Guy. I was introduced to him in a curious way. I was walking across the polo ground with "Peggy," when I passed an officer who exclaimed: "Hallo, "Bramble'!" Now, "Bramble" was "Peggy's" mother, and on inquiry the officer, who turned out to be Coghan, explained that he was in my brother's battery in Ireland, and knew "Bramble" well! He and I used to knock a polo ball about together, this being my first introduction to that game of games.

In those days every new Political Officer, on arrival at Lokoja, before leaving for his station, had to pass an examination in Revenue Suspense Account, i.e. the method by which tribute in kind is brought to account as cash.

This exam puzzled the life out of me, as I think it did most people, till later on, when I was actually confronted with the real problem. One officer who sat for this exam with me got a Treasury clerk to do his papers for him, and then took an ignominious plough! The Treasurer being the examiner, this is not without its humour.

On the same day, Stone and I got our orders to proceed to Yola and Bauchi respectively. We

1 West African Frontier Force. 
set forth together up the Benue in the Quail, a steel barge poled by eight men, and followed by two wooden canoes containing our loads. I should add that I was forced to spend a small fortune on provisions from the Niger Company, having left England with nothing but two cases of whisky and six of eatables. Information at home as to what one really required was singularly lacking in those days. Niagara, Nigeria, Algeria, andI was going to say-Malaria were but faintly differentiated between. I was further hampered with thirty cases of ammunition for the troops at Bauchi, relative to which I never seemed to cease signing manifests.

The journey, which lasted seventeen days, though teeming with interest to a novice, was a singularly unpleasant one, for the heat was typical of January by day, while the mosquitoes were unbearable by night. Try as I would, I could not keep them out of my net : and even the old stager, Stone, said he had never known them quite so bad. "Peggy" used to barge her way into my bed, which added to the discomfort.

South of Abinsi we settled to give the polers a day's rest, and go shooting. I had, of course, never done any "beef" shooting before, and was naturally very excited. To my great delight I shot my first kob (" mariya"), and later four others-with five consecutive shots. I have never shot so well since! It was unnecessarily greedy of me, I know: but I was young and ignorant, and anyhow there were no complaints by the polers, who made short work of the meat. Stone 
had bad luck, and we were both very exhausted when we got back to the barge. The only other shooting we had was at crocodiles, except aimingdrill at Stone's cook's mate, an amusing individual who thoroughly enjoyed dodging the little $\cdot 22$ bore (dashed me by Coghan) with which we pretended to practise on him, as he ran with great sagging strides across the sandbanks on which we used to camp.

We at length made Ibi, the poler's Portsmouth, where, not having seen women for seventeen days, our crew disappeared en bloc for twenty-four hours. Next day, having purchased a grey horse of sorts, and bade Stone a regretful good-bye, I crossed the river with my convoy, including a police escort for the boxes of ammunition, and made my preparations for a thirteen days' overland trek to Bauchi.

At Giddan Sarkin Kudu I got a very fine kob, and marked the place down as a hunting ground to be thoroughly covered on my return journey. The road was a horribly bad one ${ }^{1}$ - a mere bush path. On arrival at Wase the carriers, who had had an advance at Ibi to cover the whole journey, began the usual story that their money had finished, that they always rested two days at Wase : that "other Turawa ${ }^{2}$ did this and that," etc. These pitiful tales might have made some impression upon me had it not been for the fact that $I$ was equally upon the rocks in the matter of cash.

Since closed down, as the official route to Bauchi. White men. 
The Government make it-or did make it then —delightfully impossible for a newly appointed officer to draw any money for a very long time after his arrival, though he might be actually entitled to one, or even two, months' salary. The various Treasurers looked at one stonily, and the following conversation, more or less, usually ensued :-

Newly Appornted Officer. " Good morning! Ercould you let me have my January pay ?"

Treasurer. "Where is your L.P.C. ?"

N.A. OfFicer. "I beg your pardon-my rohat?"

Treasurer. "Last Pay Certificate."

N.A. Officer. "I'm afraid I still don't quite grasp ...."

Treasurer (bored). "Certificate showing the last time you drew pay."

N.A. OfFICER. "But there is no last time: I have not even begun to draw any."

Treasurer. "Well, I will wire the Treasurer Zungeru. You can call again in a day or two."

In the meanwhile one is probably ordered off to one's station before the reply comes, and goes through the same farce at the next sub-treasury. In my own case the answer did come, but to the effect that "L.P.C. had been forwarded to Bauchi"; and I had to be satisfied with "Local Allowance" 1 to date, i.e. ten days at $2 \mathrm{~s}$. It will be gathered therefore that the appeals of the carriers fell on very stony ground, and we

1 Local Allowance was originally 5s. per diem; it then dwindled, as living grew more expensive, by 1s. each year to nil. It was at 2 s. when I arrived. 
proceeded on our journey. I endeavoured, from now onwards, to assume the attitude of a man who had thousands to disgorge, an' he would, but was not going to be jockeyed. I had as a matter of fact some $10 \mathrm{~s}$. $6 \mathrm{~d}$.

The man who carried "Peggy" in a box complained that she was always shifting about, and that he could carry her no further. Of this again I took no notice, and I soon found that the best remedy for these complaints is either to ignore or laugh at them. Nine times out of ten they are only a try on.

But the source of far greater anxiety to me was the (genuine) lameness of one of the Police escort, Umoru, who was utterly unable to walk any further. It had been impressed upon me that any mishap to the ammunition would be visited on my head, if it transpired that I had omitted a single technical detail in respect of the guard; and here I was one man short, and six days from the nearest station. I took therefore what seemed to me to be the only course, and mounted him on my horse, while I foot-slogged the rest of the journey! Ingenuous me! But I was rewarded years afterwards at Maiduguri, when Umoru-now re-enlisted in the W.A.F.F.-presented himself at my house, reminded me of the incident, and begged me to accept two fowls and a calabash of eggs. Gratitude is a rara avis in this country, kindness being almost always looked upon as a sign of stupidity or softness ("lafiya" ${ }^{1}$ ).

1 The easy-going man is generally nicknamed by the Hausa "Mailafiya." 
On the thirteenth day $I$ arrived at Bauchiit being just two months and ten days since I left Liverpool. I was not sorry, for I was tired of trekking, and the carriers were in a riotous condition, chiefly due to losses at Cha-cha. ${ }^{1}$ Bauchi was a restful, Palestinian-looking town, walled all round, and connected by a fine main road (made by the Hon. Oliver Howard, Resident, who had just died under tragic circumstances) to the European station. Captain Lewis had taken over, recently. Murphy Moran was O.C. Troops, Forbes the gunner, Bissell the Doctor, and Wightwick, from whom I was to take over, the Assistant Resident, as we were then called. The last-named was particularly kind ( $\mathrm{I}$ have forgiven him for inducting me to my new office with a book of G.S.O.'s !), and it has been my pleasurable lot either to hand over to, or take over from, him on several occasions since. A man who could put his fingers on essentials, and hand or take over easily and without fuss-not, as many I have known, like one old maid letting her house to another. My quarters consisted of a miserable bush hovel-its gloom ungladdened as yet by the half-crown dole-and in it I lived for the next sixteen months.

1 The national game of chance. 


\section{BAUGHI-continued}

WE were a very happy family at Bauchi. We used to forgather at the "Scotch Club" (so called because everyone brought his own drinks) at about 6 p.m. This hour was generally signalled by Forbes ("Hell-fire Jack") roaring for his boy, and the cross-examination of his steward by Lewis 1-better known as "Louise" - with monocle screwed in tight, and finger wagging, as it were the digit of destiny.

"Allah Kai! Last night this bottle was full!"

"Yes, Sah! but for lunch___"

"Allah Kai! You lie!"

This was a favourite expression of Louise, and from my office, which was below his living-room, I have often heard something like the following brisk conversation :

"Allah Kai! You have had your fingers in the jam!" (or sugar).

"No, Sah! I tink de small boy___"

"Allah Kai! You lie! Call the small boy!" Pause.

"Small boy! You have had your fingers in the jam."

1 Killed in Gallipoli. He had been a subaltern in the 21st Lancers at Omdurman. 
"No, Sah! I tink prafs de big boy__"

"Small boy! You lie! Orderly! Kawo bulala!" 1

The unfortunate small boy always got it in the neck in the end, and always frantically appealed as a last resource for Momodu to be allowed to administer justice. Momodu was the interpreter, a soft-hearted, hideous little man, who wouldn't and couldn't hurt a fly. $\mathrm{He}$ is immortalized in the verse which Major Festing ${ }^{2}$ once telegraphed to Louise, after asking for and being peremptorily refused the services of Momodu. The lines ran, as far as I can remember, like this :

Why unnecessary ire?

Hakka nan na buga waya : ${ }^{3}$

Rather than that you should fret,

You shall keep your marmoset.

Keep your temper, little Loo,

Likewise keep your Momodu.

Poor peppery little Louise! The warmesthearted and most hospitable little gentleman that ever lived. He and Murphy Moran travelled home together that tour, and a stage or two from Ibi, in spite of Murphy's warnings, Louise took his own line of country ("short cut" he termed it) -with the result that he got badly bushed, and staggered into camp after a thirty mile trek in the last state of exhaustion. Murphy, who was genuinely concerned for him, stood at the door ready for him with a stiff whisky and
1 "Bring a whip."
s "Thus I wire you."
2 Killed in Gallipoli. 
sparklet, and a face which evidently betrayed his anxiety. Louise gave him one steady look, then, raising the finger of fate, he said : "Murphy! If you had so much as smiled, I would have shot you!" Murphy subsequently sent us a rag diagram of Louise's peregrinations-each swamp, or tangle being labelled with the expletive supposed to have been used by Louise at every fresh misfortune. Thus : "Corpus Christi! Bog." "Muckheap! Ravine," etc.

These two were admirable foils to one another. On a previous occasion on the same journey, when they were about to tackle a swollen river in a rickety Berthon canoe, there was an argument as to whether they should cross together or singly, and, if singly, who should go first. The discussion became heated, and Murphy, with a twinkle in his eye, raised the question of seniority! This was too much for Louise, who threw his cup of tea at him, and then said: "Now, Murphy, you may kill me!"

The latter, placidly wiping the Mazawattee from his bush-shirt, replied: "No, my dear horse, you are not worth it!" They were the best of pals really, and their little tilts were the joy of the Scotch Club.

About this time my cook, an impudent rasca. and useless at his job, thought fit to cut onions into strips, mix them with apricot jam, and then serve the lot up to me encased in an omelette. I had him up and inquired whether this was meant for a sweet or savoury omelette. The cook, who prided himself on his knowledge of 
culinary nomenclature, hesitated. I informed him that, if it was any comfort to him to know it, it did not in the least signify which it was, as in either case he could consider himself sacked. $\mathrm{He}$ cleared off, and went straight to Louise to complain, accompanied by my two boys, who felt it incumbent upon them to indulge in a sympathetic strike. I had already become more philosophic about such occurrences, and while I leisurely versified my bereavement, and sent it off to the Sporting Times, the cook was having a very rough ten minutes with Louise, who never did things by halves. "You lie! I charge you with attempting to poison your master, and the two boys with aiding and abetting in that_-" but before he had finished the peroration " cookoo" had effaced himself for good and all, and the boys were humbly begging to be readmitted to the fold. Which they were-at a price.

The chief amusement at Bauchi were occasional tennis, a ride round the town, or a " barewa" (Senegal gazelle) shoot. Every Saturday night Louise used to give a station dinner, followed by poker. A favourite dish of his was mutton chops, which I used to find infernally tough and pass surreptitiously under the table to "Peggy."

In May, the Inspector-General, General Morland, ${ }^{1}$ paid a visit with his Staff, including Colonel Strickland, ${ }^{2}$ Jenkins, $^{3}$ and Pragnell. Louise put

1 Later Commander-in-Chief, Rhine Army of Occupation.

a Later commanding Cork Division, and so incidentally adding to his already wide experience of Pagan tribes.

8 Later Colonial Secretary, Barbados. 
up the dinner, I think. The General was an early bed-goer, and retired betimes to his quarters in Louise's bungalow, outside which we were dining. It had been impressed upon us that he was a light sleeper and that we should talk quietly and not disturb him. The conversation waxed convivial and louder no doubt than we realized-being punctuated periodically by one or other of us saying with owlish solemnity: "Hush! We mustn't wake the General!"

Next morning at breakfast, the General observed to Louise drily, but not unkindly, "I much appreciate the efforts not to wake me last night!" "A" Company got the efficiency prize whatever.

"Peggy," who was standing the climate well, and never missed a meal, gave birth to four puppies in July. Three died, but the fourth, "Piccin," was a gem, and survived three further tours and four leaves with me. Of her more anon.

As far as I can remember it was about now that Walter Wethered, ${ }^{1}$ practically the pioneer of the Tin movement, arrived in the country. I say "practically" because the Niger Company had been established already for some time at Naraguta under Laws ${ }^{2}$ and Archibold, two of the toughest and best; while another gentleman (who shall be nameless) who had sailed with Wethered, had short-headed the latter, and arrived in Bauchi alone.

1 Died at Jos, 1914.

2 Colonel H. W. Laws, C.M.G., D.S.O. (who was directly responsible for the blowing up of the Messines Ridge). 
Louise was away for the week-end, and this gentleman tried to bounce me into giving him an advance of $£ 50$ out of Treasury funds. The power of attorney, however, which he flourished off-handedly before me, being a joint one, I suggested that the matter should stand over till the arrival of Walter Wethered, who was pounding gallantly away on a bicycle not far behind. But for good reasons of his own our friend seemed as disinclined to wait for Wethered, as he was anxious to push on to Juga, where he had "business to attend to" (sic). I cashed him (privately) a cheque for $£ 3$, which was subsequently "referred to drawer," and he passed lightly on his way.

Next day Walter Wethered rolled in-a real good sportsman of the old school-well the other side of fifty, but full of life and good stories. He very soon explained how matters stood, made a singularly accurate forecast as to the fate of the cheque, and refunded me the cash on the spot. The meeting of Wethered, the nameless one, and Huddart ${ }^{1}$ (Government Inspector of Mines) at Juga was, I believe, a very piquant affair!

The nameless one-no, he shall be called for convenience Weller-returned to Bauchi indignant, self-righteous, but unabashed, and made himself quite at home. He dashed me some topazes, but made no allusion to the cheque. At the Scotch Club he regaled us with his past achievements, and very early on I saw Murphy prick

1 Died in German East Africa. 
up his ears, and that alert look came into his eye which presaged danger for the unwary.

Weller made his first slip when he spoke of " his brother in the cavalry." Murphy, in the language of the Courts, at once rose to crossexamine. "What was his regiment?" Weller "really couldn't remember, it was so long ago, but he rather thought it was the Coldstream!" I saw Murphy settle himself in his chair, and prepare for further fun.

The second howler-or rather series of howlers-was an unfortunate allusion to his experience in Russia. Now Murphy was a muchtravelled man.

"Have you ever done the run from St. Petersburg to Vladivostock?" he inquired simply, puffing away at his pipe.

"Often," replied the undaunted Weller.

"How long did you take?" pursued Murphy relentlessly.

"Well," said Weller, "I couldn't really say now. I remember I got rather bored with the business."

"Did you go viâ Smolensk ?"

"Let me see, I do seem to remember an official of some sort calling for tickets at some such place."

"Did you get a good view of Teheran?"

"Well, you know, I slept most of the time: I did not really look."

"No," retorted Murphy quietly. "You get a better view of it, of course, in Persia!"

And so on. 
But your real liar has no sense of shame or defeat, and Weller made tracks for Ibi perfectly content with himself and the world-not before, however, he had palmed off on the colour-sergeant a case of inferior whisky under a false and fashionable label, at a correspondingly false and fashionable price, and taken a sovereign off the native gaoler in advance for two bottles of ditto which never materialized at all.

His deeds of glory were in no way confined to Bauchi. I believe that at Ibi he disposed of such baubles as camp equipment, saddlery, crockery, etc.-paid for out of the coffers of his Syndicate-for a mere trifle-paid into the coffers of Weller-and finally distinguished himself by borrowing a horse from an officer up at the Lokoja Mess, and selling it to a trader the same day.

One day an armourer-sergeant rolled up to my office. His carriers had evidently got out of hand on the road, and pulled his leg properly.

"I wish," he said pompously, "to report these 'ere labourers for intimidating of the populace, and creating terror in the villages. Might $\mathrm{I}$ address the labourers, sir?"

"Certainly," I replied, and had them lined up.

"Ku jai" (sic) ${ }^{1}$ he began, " $\mathrm{Er}-\mathrm{ku}$ jai da kyaow (sic)__" Pause, which I presumed was intended to render his next remarks more effective. " $\mathrm{Ku}$ jai," he began again, "er-might I 'ave an interpreter, sir?"

Sic transit gloria linguae!

${ }^{1}$ He meant "Kun ji : Kun ji da kyau," which may be translated freely: "Look here now, just understand this!" 
Walton, the Police officer, had a yarn about a similar sort of amateur linguist, who presented himself one day to register his rifle. "I 'ave 'ere," he said, "a weapon, Martini 'Enery, by Mr. Martini 'Enery, Niger Company weapon." $\mathrm{He}$ was subsequently overheard in a partition of the Rest-house addressing affable but wineinspired salutations to the passing ladies thus: "Sanu mata! Sanu da kyaow (sic)! Ka ji mata! Ka ji dakyaow!" His vocabulary carried him no further, apparently. But I am diverging. Louise and Murphy went on leave in August, the latter being relieved by Cecil Gibb, and Louise by Major (Brevet-Colonel) Augustus Mclintock, D.S.O. Mclintock, universally known by the natives as "Maidoronyaki," and by his friends as "The General," was one of the most notable characters in the country. A delightful Irishman, with a slight lisp and an inexhaustible supply of blarney, he would prove without effort that black was white, and then clinch the argument with "And that'th God'th truth!"

It was a plcasure to work under a man like the General, for he was big both in mind and body, without the flatulent self-importance assumed by so many in his position with far less justification. While he could mete out, if occasion demanded, a telling off which made itself felt, he was not above doing some real spade work himself; and I have known him at tax time sit at my table for three successive days helping to count thousands of pounds' worth of threepences and sixpences. 


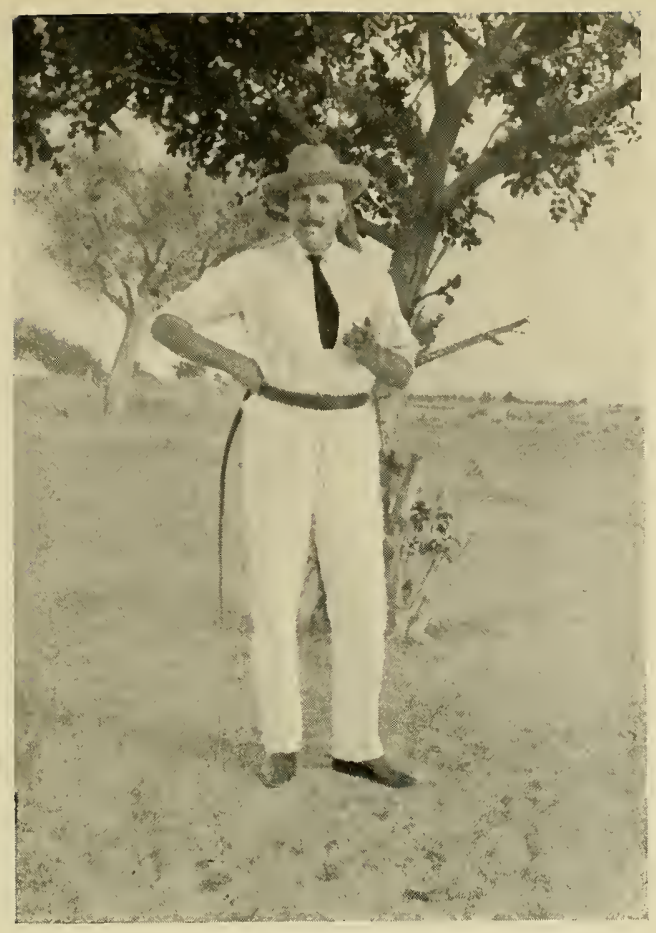

"The General."

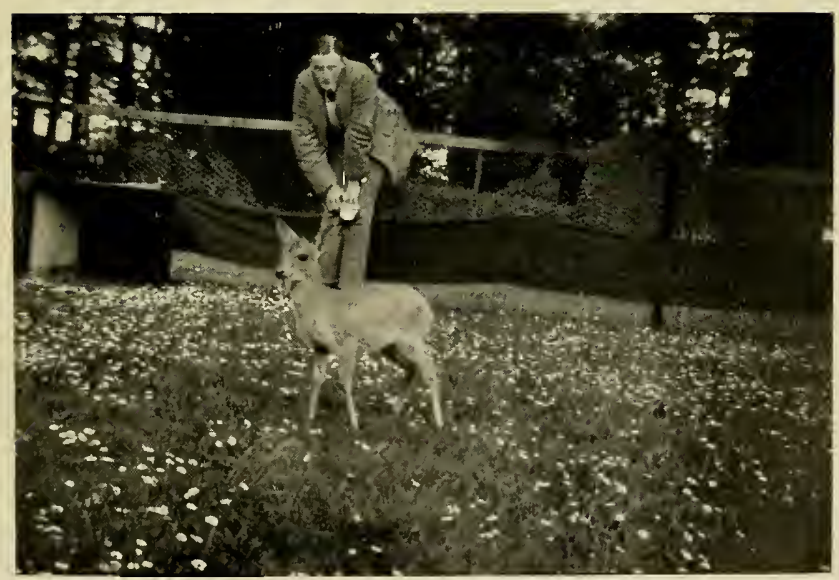

"PETER" IN ENGLAND. 

This, by the way, was I believe actually the first year that we had taken the whole tax in cash, instead of a portion in mats and cowries. We had a store bulging with the latter, and from this I had paid off the General's one hundred odd carriers (vide p. 18, "Revenue Suspense Account"), without making any perceptible hole in it. They were an infernal nuisance, 5s. being roughly a donkey's load; and it was a ridiculous spectacle to see the entire native staff assiduously counting a shilling! 1 Cowries were no longer legal tender, and of course discountenanced, but even now the market folk cling to them, and conduct their petty transactions through their medium.

The General was a devotee of the Turf, and racing held first place among the many things we had in common. Common interests are an invaluable asset in a lonely station. Having a boy called Mustapha, he backed the runner-up of the Cambridgeshire two years in succession!

He was not without his vanities. Every month he used to have his clothes, shirts, socks, etc., put out to air, and frequently would invite my inspection. "Very smart suit that!" he would say, or: "Damned dadi ${ }^{2}$ boots those, especially with the spats! I can tell you I'm not by a long chalk the worst-dressed person at Goodwoodand that'th God'th truth!" Yet, with it all, he was one of the finest soldiers in the country. "I would follow that man through Hell!" Murphy (himself a lion amongst men) once observed.

11,600 to 2,000 cowries went to the shilling : 4,000 at the timc of writing.

2 Hausa for "nice," or "chic." 
One morning Malam Duguri, the General's gardener, came to me and asked permission to borrow my 22 rifle. "A beef," he said, was "humbugging the farm." I was about to send for the weapon, when it occurred to me to ask him what sort of beef it was that was causing the trouble. With an ill-suppressed chuckle he hastily withdrew from my office, whereupon I realized that he was referring to my little pet duiker ("gada"), and that the General had put him up to pulling my leg.

The latter was devoted to animals, and if $I$ rode to the town of an evening, my various pets used to play about round his chair till my return. "Peter," the duiker, was a great character, and used to follow the boys to the market, and pinch green food off the market women, much to their annoyance. It would eat anything that it was offered, and even stand up on its little hind legs and take a cigarette out of my mouth. It subsequently lived and thrived, worshipped by the ladies, at my home in England for three years.

I have not mentioned, I think, that apart from my political duties, I was acting District Superintendent of Police ${ }^{1}$ and Deputy Sheriff, Walton, the actual holder of those offices, being stationed for political reasons with the bulk of the detachment at Naraguta. In September it was my lot, as Deputy Sheriff, to carry out my first execution. The miscreant, acting on instructions received-so he told the court in his de-

1 Now Assistant Commissioner of Police. 
fence-from Allah during the night, had battered his mother's head in.

On the day previous to the execution the General instructed me to inform the doomed man that the sentence would be carried out next morning, and to inquire whether he desired to make any sort of will or leave any message for his folk at home. I duly interviewed him through the medium of a scribe, and he replied as follows :

"There only were three of us: my brother died last month, $I$ killed the old woman, and you are going to kill me. What is the good of a will ?"

Next morning, at half past seven, we repaired to the condemned cell, where the prisoner-certainly the most unmoved individual presentgreeted us with the usual "Zaki!" His arms having been pinioned and the grizzly knot adjusted, he was led up on to the scaffold, and, without a sign of flinching, dispatched into eternity. The General, chafing to be quit of the drab performance, shouted to the gaoler (whose name was Isaac): "Jacob, my friend, that'th damned badly done! I've a good mind to puth you through too!"

And here it may be observed that, however accurately the drop has been regulated, unless the knot is adjusted exactly behind the angle of the lower jaw, the noose will slip, and death will ensue from strangulation instead of dislocation. ${ }^{1}$

1 A distinction postulated by humanity, but not, as a matter of fact, by the wording of the death-sentence. 
These were comparatively primitive days; the gallows was sometimes a tree; and one had to test the drop and the rope, as best one could, with sacks of grain. All these are gruesome details, but anything which adds to the sum total of human knowledge is worth placing on

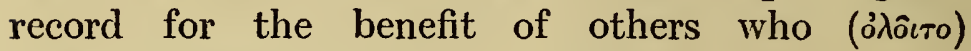
may be similarly placed one day.

A second execution took place shortly afterwards, and on this occasion the wretch, who had shot his victim with a poisoned arrow, offered me, at the usual interview, $\mathfrak{1 1 , 0 0 0}$ to desist from my sinister purpose on the morrow! On inquiries, I learnt from the scribe that the man possessed "ko toro" 1 and next morning justice took its course. He was on the verge of collapse when the bolt was released.

Isaac, by the way, was not much in front of an illiterate, but at least a tryer. Inspecting the prison register one day, I came across the following three consecutive entries:

Name. Previous Occupation.

Audu

Rufai

Mai
Thief

King

Cannibal
Distinctive Marks. Same old pox marks Do. do. do. Not so much marked : scratch on belly

One of the causes cellebres of this year at Bauchi was the burglary, during a raging tornado, of the post office, and the subsequent confession and trial of one, Suli Yola. The full story was published in the May (1915) number of Black1 Not even $3 d$. 


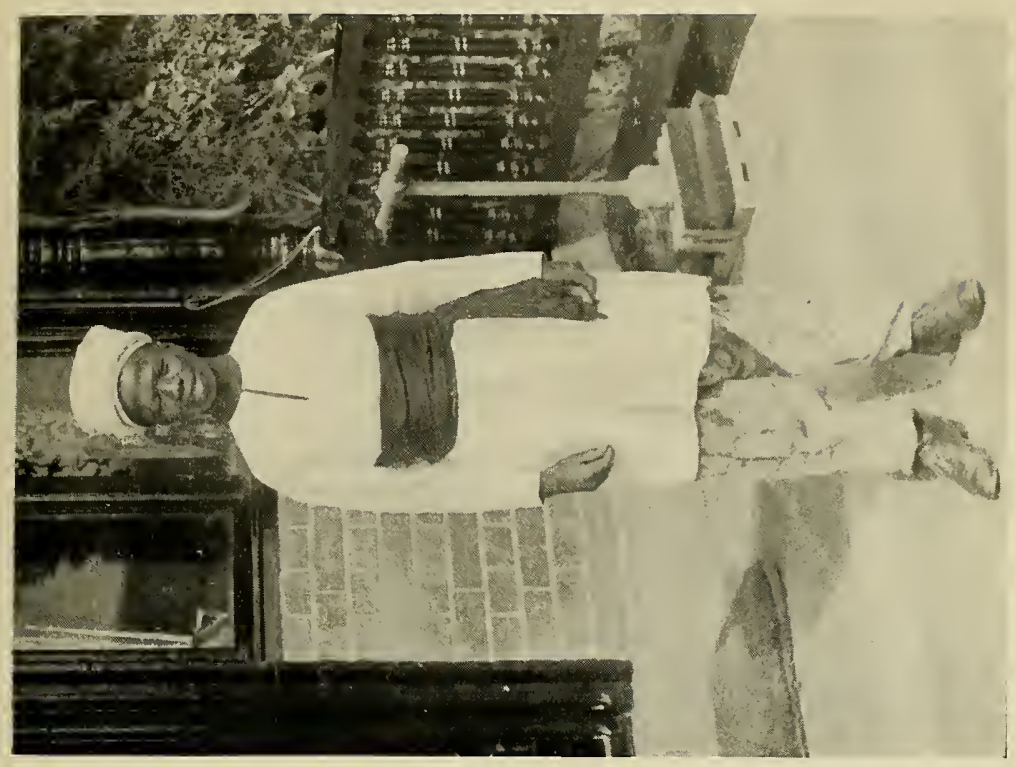

站

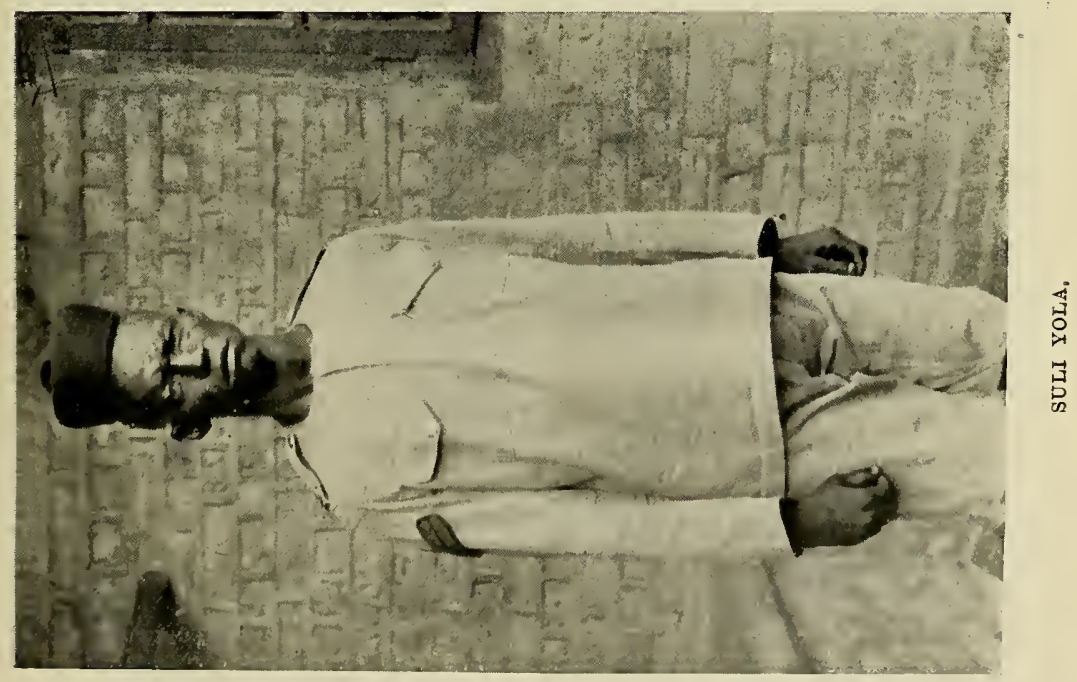



wood's Magazine, and I reproduce it in the form of an appendix (A) by the courtesy of the editor. In that article $I$ did not give this gentleman credit for half his subsequent achievements, one of which landed him for good and all in Lokoja Gaol. Not quite for "good and all," for when I last passed through that station Beamish, who was then in charge, informed me, if I remember rightly, that he had escaped more than once since his incarceration.

During one of these adventures it is reported that he was nabbed by a trader, and confined in a tank, upon the lid of which the night watchman was bid to sit in ceaseless vigil. This stratagem, however, presented no difficulty to Suli, who soon put his juju on the watchman, and escaped from his predicament. (Suli's juju was a quack nostrum consisting almost entirely of one ingredient-namely, the sheer terror he inspired in all who crossed his path. Vide the episode of the Police sergeant-major in Appendix A.) Beamish kindly gave me a photo of this celebrity, ${ }^{1}$ a copy of which I sent to Mr. Blackwood.

It was at Bauchi that I first made the acquaintance of the General's small boy, Bisalla, the whitest (metaphorically speaking) native I have ever come across. He was rescued at the age of seven from a slave caravan up Chad way by Mr. Hewby, who passed him on to the General, and after the latter's tragic death he came into

${ }^{1}$ Greene, the Station-magistrate, has since informed me that Suli is now again a corporal in the W.A.F.F.'s! and kindly supplied me with the photo reproduced in corroboration. 


\section{ORR RELIEVES THE GENERAL}

my service, where he has been ever since. Having practically never known any father but the Whiteman, and only changed masters twice in fifteen years, he has been a singularly loyal and faithful servant; and his visit to England with me in 1912 - a severe test of a boy's susceptibilitiesleft him quite unspoilt.

In October the General was relieved by Captain Charles Orr, ${ }^{1}$ and proceeded viâ Nafada to take over Bornu from Mr. Hewby, who was due for leave. Pollard (who had taken over in April from Bissell, as Medical Officer), Gibb, and I rode out with him as far as the town wall. A guard of honour had been posted by Gibb on the town road, at which the General seemed very much moved, and we were accompanied by the Emir and his entourage. We then bade him a solrowful farewell, and Gibb and Pollard never saw him again.

1 Now Colonial Secretary of Gibraltar. 
CHAPTER III

\section{BAUCHI-continued}

ORR was as different from the General as two men could be. Whereas the General was impulsive, with not infrequent flashes of brilliance, Orr was methodical, and essentially sound. Anyone wishing to get a grip of what we are "driving at," and how we went about it from the day we took over from the Royal Niger Company, could not do better than study "the account of "our stewardship," as Orr neatly terms it in his Making of Northern Nigeria. With a considerable experience of secretariat work, he had had as rough a taste of the practical difficulties of administration as any man in the country when working singlehanded as Resident in the early Zaria days. He had also given valuable assistance as a member of the Lands Committee in its investigation into the system of land tenure in Nigeria.

In November Walton became seriously ill : in fact, his life was hanging in the balance, when Doctor Emlyn, of the Church Missionary Society, arrived and pulled him through. I was therefore instructed to proceed to Naraguta, and take over the Police, prisoners, office, and stores, and transfer them to Bauchi. When I arrived there after four perfect moonlight marches, Walton was con- 
valescent, and I spent a most enjoyable week with him. It was delightfully cold weather, the house was comfortable, with a good garden, and Walton knew how to do things well. What with putting the Police through their musketry, taking over the stores, and writing up the monthly accounts and vouchers, ${ }^{1}$ I was kept fully occupied without being overworked. Wightwick also used to pay us periodical visits from his Bukuru fastnesses.

Sir William ("Baba") Wallace, , who was at that time acting as Governor for Sir Percy Girouard, was just completing a visit to the Niger Company Mine, when I arrived, and was due to leave the following day. Walton asked me to turn out a guard of honour for him on the Zungel'u road.

At 5.30 a.m. I rose, rode out with the men, and duly placed them in position. With teeth chattering with the early Plateau cold, I sat and waited for him. About seven o'clock Cocks, his private secretary, strolled up smoking a pipe. I asked him if Sir William was far behind. "More like two hours in front!" quoth Cocks. "Baba is an early bird!" I had to gallop ahead, and tamely inform Sir William what a fine guard he had missed! I added that Captain Walton would be very sorry about this (I thought this was rather clever, as it shifted the responsibility from myself, and secured Walton a little cheap sympathy), and I remember his exact reply:

1 Required in triplicate in those days.

2 Died 1916. Vide also Imperial Library Series, British West Africa (Mockler Ferryman), p. 269. Also Vandelcur's Campaigning on the Nile and Niger. 
"Tell the laddie not to worry about guards, but to hurry up and get well!"

It was at cocktails the previous night with Baba that I first made the acquaintance of that best of bons garçons, Laws, manager of the Niger Company Mine, and chief consulting engineer to this, and later to most of the other companies. Tin was "in the air" just now, and at a dinner given by the last named I met Lush (who had come out to report on certain properties), Huddart, Walter Wethered and Molyneux (now established at Juga), and Maclaverty. But what a contrast was the lonely, picturesque, and peaceful Naraguta of that day to the pandemonium I found on my return next year!

During my stay I paid a flying visit to Ngel, in a futile effort to get a buffalo, and there enjoyed the unconscious hospitality of Carpenter, who was running an offshoot mine of the Niger Company. He was away on trek, and I camped in his quaint little grass house surrounded by cactus. On my return, I thought it wise to send "Peggy" back to Bauchi with the small boy, as another important domestic event was imminent! I followed a day or two after with the Police and Walton's dogs and horses.

One of these dogs rejoiced in the name of "Smut." He was an amorous beast, and had for the last three weeks been conducting a love-affair at Bukurua distance of seventeen miles, which he would think nothing of covering in the day and returning at nightfall. He was now consequently worn more into the resemblance of a toast-rack than a dog. 
I arrived at Bauchi on Boxing Day, having spent Christmas alone at Katsenawa. I found Orr down with fever, and Colonel Mackenzie ("Costive Mac") looking after him-himself to die of blackwater fever only a month later at Yola.

The compilation of the annual Police and Prison returns, without the aid of an inspector or a clerk (as one has now) in addition to my other work, had left me rather jaded after a contimuous year in the office, and I was beginning to feel the effects. Orr now promised me that, if the M.O. would sanction a short extension of my tour, I might go off on a visit of inspection through the northern districts. Unfortunately $I$ had a bad series of malarial ulcers, which lasted for a month; and it was with some difficulty that I persuaded the M.O. to favour an extension.

In the meanwhile nothing of particular interest occurred, bar the double execution on the same day of two wretches who had for a long time been waiting confirmation of sentence. Orr was still seedy, and retired after the first murderer had expiated his crime, leaving me to dispatch the second.

Legion are the tales of executions in this country, where it is in the very nature of things that comedy should link arms with tragedy. On one occasion in days of yore the story goes that the Police fell through the trap embracing the victim; on another the rope broke, ${ }^{1}$ and the should-have-

1 I was a member of the Board of Inquiry into this affair. I remember reflecting that this was probably the only "inquest" ever held as to how the victim came to be alive ! 


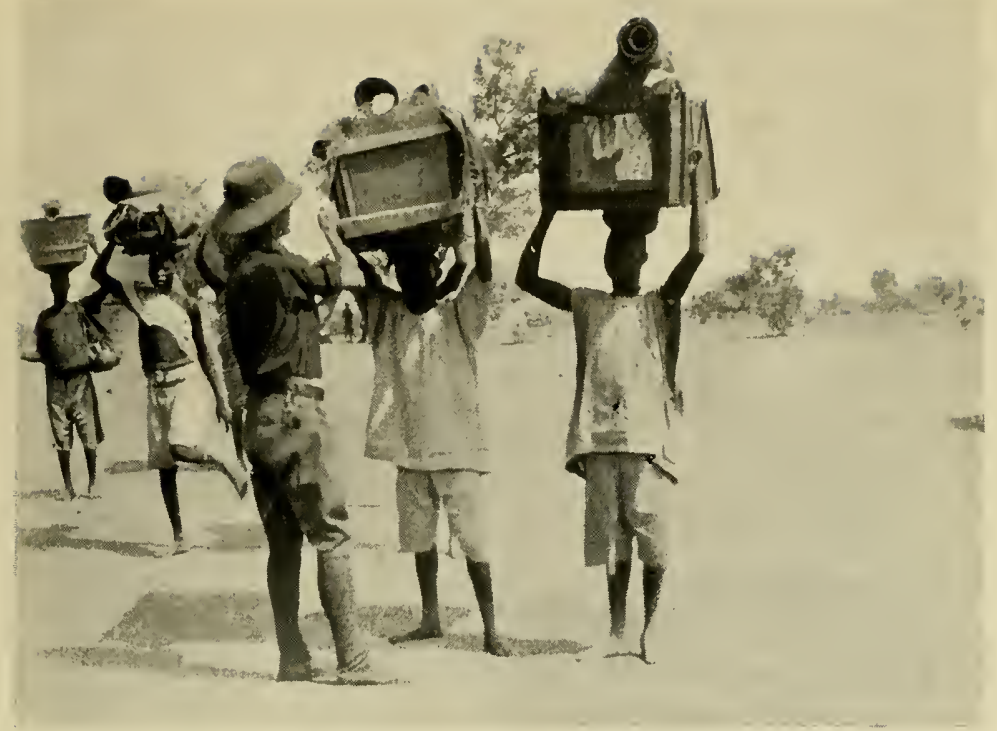

POLLARD LOADING UP THE "MENAGERIE,"

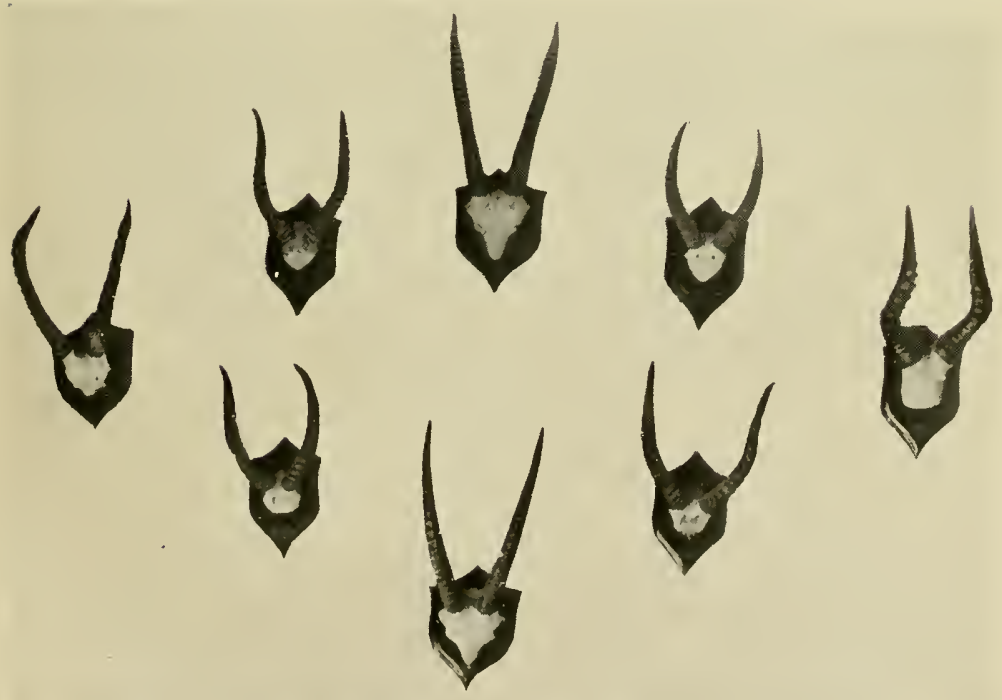

SOME TROPHIES. 

been deceased, when marched out for the second time a week later, together with a newly sentenced fellow prisoner, was heard explaining to his mate that there was only a bit of a jolt, and that last time he was back to lunch! On yet another occasion a young Political Officer-new at the job, like myself, and horribly nervoushad made drops and tests and rehearsed the grim ordeal till he felt that nothing could go wrong. Nor did it, save for the noose, which, in a moment of temporary aberration, he had forgotten to put round the victim's neck! Bathgate once witnessed the execution of an Asaba youth who burst into dance and song, the chorus of which ran: "Goodbye-oh! I die-oh!" ere he disappeared from view.

On February 24th I handed over "Peggy," "Piccin," and "Peter" to Pollard, who was kind enough to take them home for me, and we set forth on our respective ways-Pollard for England, I on my northern tour viâ Gombe to Hashidu where I had to investigate a land dispute, and on to Karia Wudufa.

I should explain that the latter town, situated in a corner bounded by Bauchi, Kano, and Warji, had sent to the General a very clear intimation that they would fight rather than pay tax. This tax was still outstanding.

Orr instructed me to investigate the grievances of this town, and, if I deemed fit, to reduce the tax originally imposed. It not unnaturally occurred to me to inquire mentally: "But how about it if they $(a)$ refuse to pay at all; $(b)$ rub 
in their refusal with the poisonous end of an arrow?" As a corollary to this query arose the question of an escort. I must add that this town had already previously put up a fight against the Police in Howard's ${ }^{1}$ time; and that I further had fresh in my mind the recent ambush and murder of Van Rennen ${ }^{2}$ in the next province, and the escape by the skin of his teeth from a desperate situation by Foulkes in my own. But, being young and ingenuous, and not wishing to incur the suspicion of timidity, I kept my own counsel and said nothing. It was of course the old problemthe sense of ridicule (in the event of force not proving to be justified) conflicting with discretion. I am wiser now. Cui bono the maxim and the $\cdot 303$, if one is going to put oneself within arrow range? Be that as it may, I set out with a light heart, and keenly enthusiastic at the prospect of good shooting in the Ninghi hinterland.

At Keffin Iya, one of the stages of my trek to Gombe, I saw no less that seven hippopotami barging about a lake too deep to make shooting them profitable. A native of this town informed me that his grandfather used to squat in a bush by the river side of a night, and rip these monsters up the belly with a knife as they landed. He showed me the knife it was done with: a deadly, weapon, but a brave man the wielder withal. Birds of all sorts were plentiful on this road, and I practically lived on them till my cartridges ran out.

1 The Hon. Oliver Howard died at Bauchi, September 1908.

${ }^{2}$ Killed 1909. 
Having slept the night at Gombe, the seat of that Emir, I crossed the Gongola, and camped at Hashimiri. I here had to settle a dispute about farms between the Sarkin Hashimiri and the Sarkin Hashidu, two very grasping and semiticlooking gentlemen, who both appeared to be out for "something for nothing." Having patched up the palaver, I made them wring each other's hands ; but they looked as if they would far rather have wrung each other's necks. ${ }^{1}$

I proceeded thence north-west to the imposing town of Darazo, where the District Head met me, and did me handsomely-or rather his brother did, for the former was a dismal individual with a wry neck, who seemed to be unable or unwilling to open his mouth. I shot some fine marabout near here, and camped the next night in a tent in the bush. It was desperately hot at this time of year, and I simply stewed in the tent. That evening I struck a herd of hartebeest ("kanke "), and shot a very poor specimen.

I now passed along the southern border of Kano Province. I was struck by the primitive appearance of the people, who had, so they told me, never seen a white man before. It was intensely hot, very rough going, and I felt far from fit.

The next day or so brought me within a stage of Karia Wudufa, and I was informed here that that town was preparing to fight. I sent a message to the chief to say that I should camp at his town next day, and should expect wood, water,

1 Pembleton recently informed me that he was still "settling" this palaver in 1921 ! 
and provisions (the usual courtesy extended to any stranger by the humblest hamlet). I received no reply, nor, next day on my arrival at the place, was there anyone to meet me. The Madaki, District Head of these parts, had erected a rough grass rumpah for me, and here I camped. Wood and water, etc., had to be obtained from neighbouring villages who were loyal to the Madaki.

Karia Wudufa stood on a hill formed by tier upon tier of massive boulders, and honeycombed with caves. From one of these, about five o'clock that evening there emerged an elderly man, clad in a rough gown, who informed me that the town was divided into two parties, his own and the hostile faction under the chief. The present trouble, he said, was due to the chiefs of Manako and Warji having levied an annual tax on this unhappily placed town, in addition to that claimed by Bauchi. I informed him that I had come to discuss this very matter, and if possible remedy it. He produced a few shillings collected from his own quarter as an earnest of good faith, and volunteered to take me to the sarki's compound, but warned me that, at any sign of force on my part, bees would be loosed upon me.

Accompanied by this cheerful person, who called himself Sarkin Fada, and by my interpreter Jagaba, and with a revolver stuffed in my trouser pocket, I ascended the hill. I must confess at once that this was an obvious error on my part, for it was up to the chief to come and see $m e$, and not to me to clamber up the rocks to see him.

On arrival at the summit, and turning to the 
right, we came into the market, and there a far from reassuring spectacle presented itself to me. A crowd of nude, forbidding-looking natives were grouped together, with bows and arrows in their hands, and pots of what I rightly took to be strophanthus-a deadly poison-by their sides.

There was no sign of greeting, and I had to open the conversation. I asked for their sarki, and was informed by a scowling ruffian that he was away on a visit. I then told them that I had come to discuss their grievances with them, but that I could not do so except through their chief, whom I knew to be concealing himself. They replied sullenly that if I would go away they would send some grain into Bauchi in lieu of tax. I declined this proposal, and informed them that their chief and elders must come, with the usual provisions, to my camp and discuss matters there. This suggestion was received in dead silence. With my back glued to the wall of a hut, and sweating not a little, I remarked tentatively that "I did not wish to send for soldiers." (There was nothing on earth I wished to do so fervently at that moment!) A continued silence, however, showed me pretty clearly that the interview was at an end as far as they were concerned. I therefore gave them till nine o'clock the next morning to come in or take the consequences, and proceeded on my return journey down the hill.

My courage 'was at zero, and my skin like gooseflesh as I passed each crevice and cave on the return journey. I reached camp, however, without mishap. 
I have stated that I made an error in going to visit the folk of Karia Wudufa, instead of making them visit me. I now, in my naïveté, made a second in not withdrawing to a friendly village, and insisting on the chief visiting me there. As it was, I thought such a step would be regarded as a sign of weakness by the natives and of "funk" by the Government; so I decided to sleep where I was. Having no guard of any sort, the only precaution I could take was to post Jagaba and Rumfah to keep watch altemately at a point of vantage whence they could keep the town under observation, and to leave a lamp burning all night in my hut to give the impression that I was awake and on the alert. My camp, be it remembered, was almost within arrow range of the hill.

Next morning some of the elders came in and offered in half-hearted fashion to compound with two goats and a sack of grain. I told them I had not come to bargain, but to discuss their troubles: and this I would only do with their chief, who they now said was sick. Being tired of their prevarications, I kept five of them as hostages, and sent the sixth back with my ultimatum that, unless their chief complied with my previous demands, I should send for troops. He never returned, and next day I wrote for an escort.

I now went down with a severe attack of dysentery, and was on my bed for three days in great pain and exhaustion. I was horribly short of food, and had no drugs of any sort bar quinine, while the sun simply sweltered through the thin grass roof. On the fourth day I received a letter 
from Duff, who was taking over from Orr, saying that he had applied to headquarters for sanction for the patrol. Feeling a little better, and not rclishing the prospects of delay, as the lonely nights were getting on my nerves, I made my third error. I decided to take matters into my own hands.

At five o'clock that evening I resolved to distrain on the grain supply of the town, and realize it to cover the tax due. Giving Rumfah (an expolice sergeant, who had had a previous fight with this town) my $\cdot 450$ double-barrel express, Jagaba my shot-gun, and myself armed with a -303 and a revolver, I paid my second visit to the town. Having posted my army of two on commanding rocks, I summoned the Madaki's people and my labourers to come and carry the grain. The Sarkin Fada showed me where the bins ("rumbo") were, and, as the inhabitants had retreated into their caves, operations proceeded smoothly enough.

At 6.15 p.m. I descended half way down the hill to call my boy to bring me writing materials, as I was now rather pleased with myself, and intended to countermand the escort. No sooner, however, had I left the brow of the hill than I heard the ominous boom of the $\cdot 450$, which was immediately followed by the bark of the shotgun, and simultaneously a volley of arrows whistled past me. Two hit and bent against the rock on which I stood, and another pierced the singlet of the cook's mate, who was standing at my side, carrying my ammunition. He was very disgusted ! He had volunteered, with the main eye for possible 
loot, but now indignantly ejaculated: "Haba, kai! Wanan ba wasa ba ne!" 1

Shouting to my messengers and the rest to clear out at once, I emptied my magazine into the figures who were now swarming out of the caves and up the rocks. Sarkin Fada told me afterwards that I had killed one and wounded two of them, but this, I fancy, was "zuman baki." 2 It anyhow had the effect of checking them, and we got back into camp without further molestation. My act of impatience had of course only made matters worse, as I had now aggravated the enemy. Added to the delay which was in no way lessened, I had given them increased incentive for a night attack.

I have admitted my mistakes, yet I think a good many other white men would have taken the same course, rather than lie down under the studied insolence of these rock-folk.

On the 15th of March, Parker turned up with about forty men, and the Medical Officer, Bissell, who had relieved Pollard. I think I cannot do better here than quote from my rough diary as to the proceedings which ensued.

March 15th.-Troops arrived and had breakfast, and, after warning the enemy to remove all their women, went up hill. Section posted behind hill and the rest round the summit at intervals. The Sarkin Fada went into a cave to call or pretend to call for surrender, and almost simultaneously five arrows whistled up from below, narrowly missing the sergeant-major. The foe

1 "Fie! This is not play at all!"

2 Said to please. 
were completely hidden and it was almost impossible to get a shot in. Meanwhile I got to work and carted their grain and beans away in baskets by labourers and men from friendly neighbouring villages. Periodically we got shots home, and in their turn they suddenly fired some arrows at my transport party as they went down with their loads, and frightened them so much that I had the utmost difficulty in getting them to come back. I then made them demolish as many houses as they could, and I fired all the grain I found. This took us till 3.30 p.m. and we were all hopelessly done up with heat of the broiling sun, the fire, and smoke, which a northerly breeze brought straight at us. I had not touched solids of any sort for five days, and could hardly stand. According to Sarkin Fada we had killed and wounded several of them, and I now asked Parker to cover my labourers' retreat and withdraw his troops till the next day. We hoped they might surrender, and all men, white and black, were tired and famished. In the evening Parker took out seven men and shot two more as they slunk out to get water, and intermittent sniping went on. I sent frequent messages to them, saying I would cease hostilities if they would come in, but they always refused, apparently feeling secure-as indeed they were-in their caves. It is difficult to know how to get at them. They still fire at any of the Madaki's men who go near them without an escort.

March 16th.-Attacked the hill very early in the morning before breakfast. Unhappily, the Sarkin Fada, thinking the fact that he wore a gown would protect him, suddenly emerged from the caves, and was shot through an arm and a lung by the advancing troops. Bissell and I did all we could for him, and he admitted he had taken the risk against the advice of his followers. I got to work, carted out of the town all the grain $I$ wanted with the aid of the friendly tribes, who put garlands round their heads for fear of getting shot, and fired all the rest. By twelve o'clock the town was in ruins, our 
eyes were bloodshot with smoke and dust, and I decided I had donc all I could. I then asked Parker to withdraw troops, as we had harassed them pretty severely, and I have left them no grain, and they'll have to wait till October for the next crop; moreover, they won't have anything like time to build again before the rains. I sent three of their elders back with a message that I should go on periodically bringing troops till I found they settled down peaceably on the plain. Not entirely satisfactory situation, but the best $I$ could do-as I have not the time to sit down there indefinitely. I am inclined to believe the assurances given me by refugees that the spirit of the place is broken, and that they will never return again to their hill. I have sent their chief, who came in sullenly, into Bauchi with a warrant for trial. 


\section{CHAP'TER IV}

\section{BAUCHI-continued}

"Parturiunt montes!" it may perhaps be exclaimed. But the mouse came forth, and settled on the plains never to return, which was the object we wished to attain.

I now continued my journey, passing through the districts of Warji, Ari, Burra, and Ninghi. From Warji I sent back to inquire after the health of Sarkin Fada, who was still alive. The messenger took some opium and one or two other drugs. The former evidently gave relief, as the sick man sent to thank me, and asked for more. $\mathrm{He}$ also informed me that the rebel faction had already started building on the plains, and would never kick over the traces again.

I found it necessary to arrest the Sarkin Ari on various charges of tampering with justice generally, and in particular of hearing cases on his own in camera, especially divorce suits, as a result of which the female party was invariably summarily added to his own seraglio.

At Burra, during the night, a lion got into the town and carried off an unfortunate woman. The hills round these parts were swarming with leopards and hyenas, and at a village between Burra and Ninghi, a hyena sprang in over the 
sleeping forms of my boys and collared my goat. I can still hear the sickening scream it gave as it was torn from its tether, leaving-I could never discover how-its entire lower jaw behind. I was consequently reduced to drinking hot muddy water in lieu of tea-that luxury, and my last tin of milk, being finished at Karia Wudufa.

The heat seemed to grow fiercer every day, and I had a perpetual headache, due no doubt to my trying to combine long treks with longer shoots, and never being really fit for either. I was by now well into the Ninghi Bush; but, though I saw tracks galore of all sorts, I struck nothing in the flesh. At one place, in desperation, I organized a grand drive, without result, and it became clear that I had come at the wrong time of the year. ${ }^{1}$ Mamuda, ${ }^{2}$ Sarkin Ninghi, had certainly done his best for me.

And here a few general observations on shooting in Nigeria from an amateur's point of view may not be out of place. I hasten to state that, as far as I am concerned, I am an indifferent marksman both at the range and on safari; my conclusions are therefore only to be taken for what they are worth, based as they are purely on my own personal experiences.

The best time of year for shooting is about May or June, when the early rains have brought on

1 Grier has since told me that he went on a similar tour there at about the same time in 1912, and got practically everything he wanted-which illustrates the glorious uncertainty of "safari".

2 Now an exile in Ilorin. 
the new grass, and when the beef no longer have to wander long distances into the bush in quest of food and water. Moreover, in the riverain tracts the grass, which, if it answers to burning at all, answers much later than elsewhere, is not thick and impenetrable as it is from August to March. (I have of course particular places in mind.) It is needless also to add that the damp ground makes tracking easier.

Huntermen are for the most part undependablepartly because they suspect that you have come to pry upon, or confiscate, their gear; chiefly because they do not want to "give away" their own hunting grounds. Their information, bar what is self-obvious, must therefore be taken cum grano. Huntermen have often told me that there was no beef where they lived, simply because they thought that to say there was would be an admission of guilty knowledge, and that they would be "caught" for shooting. (The position of a hunterman is not clearly defined. In some provinces they are not allowed at all; in others discouraged; in others, again, only allowed to shoot on a permit.) Once a hunterman has put me on to the tracks of game, I make him follow instead of preceding me. The chances of his ruining a shoot by not spotting the quarry, when it is standing and looking at you, more than balances those of his seeing it before you do. This is not altogether his fault, as he is probably studying the ground, while you are looking all round. The occasions when he has gone gaily on, and given the alarm to a perfect target, before 
I could attract his attention; or shouted "Gashi ! Gashi!" I long after I had seen it, are more numerous than I care to remember. Except for the purpose of guiding one into a game area, and skinning, etc., afterwards, the "mai-harbe" is more nuisance than help. There are of course exceptions.

Shooting on Trek.-It has been worked out by men who know something about it that for every male head of game one secures one treks fifty miles. I believe this to be no exaggeration. This is not like East Africa, where you take your choice of quarry at leisure. Here the problem is to find anything at all, and then think yourself lucky. Therefore you require everything in your favour-fitness, keenness, and freshness. If you have before you the average trek of sixteen miles, and you leave the road to go shooting, you never know where you will end up; and, being probably already fatigued with the march, you are apt to be half-hearted, when the quarry begins leading you south-your objective being north-and half-heartedness is fatal.

It is something like hacking fifteen miles to a meet, and nursing your mount during the run, instead of letting it all out, because you have in mind the return journey, plus any extra mileage the distance covered in the run may involve. In this country you have got to "sweat blood," as the saying goes, and you don't want to add a wearisome trek to your peregrinations in the bush. Shooting expeditions should therefore start 
from camp, whenever time permits, and not be interleaved with the trek. If one spies anything from the road it is a different thing from going off "on spec." I have perhaps made heavy weather about this; but I have caused myself more gnashing of teeth, through becoming exhausted just when stamina was most required, or being put off following a wounded beef by the prospect of never making camp, than I care to confess.

Arms. -I have found the $\cdot 375$ to be the ideal weapon. The $\cdot 303$ is not quite big enough, unless you are sufficiently close to make certain of a vital shot, while a $\cdot 450$, or bigger bore, I find too heavy, and personally I am put off by the recoil. The 375 (I am speaking of the B.S.A. Express, not the Manlicher) is light, and beautifully balanced. With it I have shot nearly every kind of big game from elephant downwards.

Ammunition.--It is a much argued point whether one should use hard or soft-nosed bullets for the bigger animals, such as elephant, etc. The argument in favour of the hard is that it will penetrate bone, whereas the soft may flatten itself, and have no effect. That against it is that it will go slick through a non-vital part, inflicting no appreciable damage, while a soft-nose will break up and play sufficient havoc with the guts to put the victim hors de combat. In the case of an elephant ("giwa "), rhinoceros (" mairiri"), or hippopotamus ("dorina"), I advocate the hard, in view of the hide as well as the bone. For a bush-cow ("bauna"), as the buffalo is commonly 
called here, I should always use soft-nose, as, in my opinion, the advantages more than counterbalance the objections. ${ }^{1}$

Position.-Chacun a son goût. Personally I do all my shooting standing. Kneeling is all very well, but the snap of a twig as one drops on the knee upsets the whole apple-cart. Moreover, having got safely into this position, you often find a maddening blade of grass just interfering with your view.

Skinning, etc.-The neck skin should be severed well into the shoulder: you cannot cut it too far down. This is necessary to allow for shrinkage: also, a short neck looks hideous when set up. Every particle of flesh should be carefully cleaned from the skull and the mask (especially round the mouth and nose). The skull should then be buried in the ground for seven or eight days, and water constantly poured over it, till the insects have eaten it clean of everything but the bare bone. It should then be washed, and the horns, which will now slide off easily, rubbed inside and out with kerosene. (Some people prefer. boiling their skulls, instead of burying them, but I find this is apt to make the bone over-soft; and to warp the horns in the process.)

As regards the mask, this cannot be taken in hand too quickly. It should be borne in mind that-especially in the wet weather-it is a race between the sun and the damp, and the damp generally wins. The mask, which should be cut vertically down the back of the neck, after thorough

1 I believe that this opinion is not commonly held. 
cleaning, should be turned inside out, spread in the sun, and then treated with some sort of arsenical preparation for preference-failing that, wood-ash. Naphthaline is also a good preservative. Never leave it to the hunterman. He will either cut it down the front of the neck, which will mean the stitches showing when set up, or will drag the skull through without cutting the mask at all, and then proceed to stuff the mask with grass (probably damp) which he thinks is killing the germs, but which, as a matter of fact, will bring all the hair out in a couple of days! I speak from bitter experience!

But, to return to my journey. Leaving Ninghi behind, I struck southwards through the region marked on the maps "UNINHABITED Bush"a just description. It was the most miserable trek I have ever done. We frequently lost our way; the natives, who had never seen a white man before, if they did not run away, gave us very little assistance; and to cap my trouble, Umoru, the small boy, became seriously ill, frequently being delirious. He had developed guineaworm ${ }^{1}$ at Warji, and the worm, enticed with water to protrude its head, had broken off so often that we despaired of ever getting rid of it. I made a rough stretcher of guinea-corn stalks, and on this he was carried, more dead than alive, for the rest of the journey into Bauchi.

For days we plodded on through this desperate country, Yaro performing miracles of endurance, and at length, just six weeks from the day I had 
started, to my great relief I brought my long journey to a close. Orr arrived the same day from an equally strenuous and weary tour through the Dass and Angass country. He had fared a degree worse than I had-his small boy having died of small-pox during the trek.

On April the 14th I left Bauchi en route for England. Parker, a great shikari, had told me where to look for beef. He had shot practically everything worth shooting in these parts, except $a$ roan, when posted at Giddan Sarkin Kudu years before, during the British advance on Bauchi. Near Katagum I met a weird-looking bushman, who, seeing my rifle, ran forward and asked me what I most desired to shoot. I naturally replied a roan ("gwanke").

"Get up early," he said, "and wear this!" Whereupon he presented me with a leather wristlet, or " kumbo," and disappeared.

I took his advice, and the juju worked: for, at seven o'clock the next morning, I ran into a herd of roan! They were as much taken by surprise as I was, and stampeded, with the result that I had to be content with a female. It is a further coincidence that I have never had such good shooting since as I enjoyed during that trek to Ibi with the kumbo on my wrist! I shot two fine hartebeeste ("kanke"), a reedbuck ("kwantanrafi"), a kob ("mariya "), and most of the smaller fry.

South of Wase I met Dix, who was proceeding to Bauchi to take over the Police. He had brought along with him two loads of provisions sent to 
me by friends from Fortnum and Mason. They had been repacked in two cases at Ibi, and one of these bore the legend: "Heidseck Dry Monopole." Taking the case at its face value, I invited Dix to split a small bottle with me, and we sat down on the hot dusty road, with mouths watering, while Yaro opened the box. Alas! The only "small bottle" of any sort was one of eaude-Cologne!

Dix, I found, had been on Crabbe's staff, with my eldest brother, in South Africa. I swopped a boy of mine for one of his. His turned out to be wanted by the Police : mine, I learnt afterwards, achieved celebrity for the satisfaction he gave the ladies of Bauchi.

At Gerkawa I sold one of my horses to a policeman for £3 10s. He paid me a sovereign, and promised to send me the rest on pay day. Needless to say, I have never seen the money (or the policeman) since.

Nearing Ibi I met Captain Ruxton and wife (at whose hands I was afterwards to meet with so much kindness in Bornu), and had the privilege of sharing with that charming French lady a bottle of "Paris bonbons," which formed part of the Fortnum and Mason consignment.

Having arrived at Ibi, I had hoped to have a bit of a loaf and some more shooting, as no barge was available. Next morning, however, Thompson-better known as "Wild Thompson," or "Tammie Tamsin"-put in an appearance hot-foot from Bornu viâ Yola in the poling barge Osprey, and announced his intention of pushing 
off the same day for Loko, whence he was to make forced marches overland, to get to Zungeru in time to sit for his exam for his Captain's step.

We had lunch with Dr. Foy. The latter ordered his boy to fetch something, I forget what, in rather laborious Hausa.

"I suppose, Foy," said Thompson, "if you really want anything done, you say it in English ?"

"No," replied Foy, undefeated, "if I really want anything done, I get up and do it myself."

Thompson's practical jokes and escapades were a byword in Nigeria. On one occasion he was asked by the Resident for an escort to convoy a safe across country. The Resident further explained that the safe would be best mounted on four cross pieces, thus :-

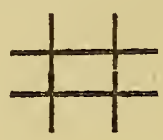

Thompson promptly filled in the diagram as under :-

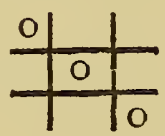

$I$ win!

H. C. T.

and returned it!

$\mathrm{He}$ was never at a loss for repartee. I once happened to mention a friend of mine by name. "Oh, that ass!" he interjected.

"Have you ever met the man ?" I asked him coldly. 
"No," said Thompson.

"Then why call him an ass ?"

"He must be an ass, or he wouldn't be out in this dam rotten country," was the retort.

When I met him, his impending examination appeared to be weighing on his mind, and he was not so unruly as usual.

We left Ibi that evening in the Osprey. Our cellar being rather depleted, Thompson suggested that, on sighting the next European, I should get on my bed and do the sick man, while he solicited a bottle of brandy. We were singularly unfortunate in our venture! Shortly afterwards a barge hove into view, and I duly got on to my bed, while Thompson hailed the traveller. Suddenly I heard a groan from Thompson, who informed me that we had "struck a snag." 1 The traveller turned out to be a missionary, who not only appeared to possess just so much as, and no more than, the clothes he stood up in, but actually begged some tea off us!

The next barge we encountered Thompson took the precaution of scanning with his glasses, while I went through the same pantomime as before. "Another snag!" he snapped, "it's Baker."

Baker was an old W.A.F.F. bird, and not the sort to be had. Even the crocs left him severely alone, as he took his daily bath among them.

The third and last barge we met nearing Loko, and it contained a third snag in the shape of

1 A metaphor taken from the bumping of a barge, or steamer (generally just as the 'bosun has declared "No sounding!") on a sandbank or other submerged obstacle. 
Jimmy Finch. We all dined together that night at Loko, and though Thompson cunningly offered to "run the mess" (which was a euphemism for taking charge of Finch's chop-boxes), we got no more out of Finch than he did out of us. We shall renew our acquaintance with J. Finch in a later chapter.

From Loko Thompson passed away to Zungeru, and, needless to say, arrived there too late for his exam! Three days later I reached Lokoja, which place I found plunged in gloom, news having been just received of the death of King Edward.

I spent the next two days in the depressing occupation of sitting for my Lower Standard Hausa Preliminary, which I managed to pass, and then embarked on the Valiant for Forcados. My companions were Bobbie Ellis, Gerald Uniacke, and Migeod. We reached Burutu in a thick fog, and clambered up the side of R.M.S. Nigeria (Captain Minto) at twelve o'clock midnight. 'There we found Laws already on board, which, with the purser, Mr. Fothergill, made our table complete.

The latter, whose nicety of diction and insistence on strict veracity was quite Johnsonian, was, so to speak, Chairman of Committee at the daily meal. The following is a sample of one of our debates :-

Uniacke. "Very excellent, this wine of yours, Mr. Fothergill!"

Mr. F. "Well, I wouldn't go so far as to call it excellent."

Migeod. "No. Just a wee bit full-bodied, perhaps." 


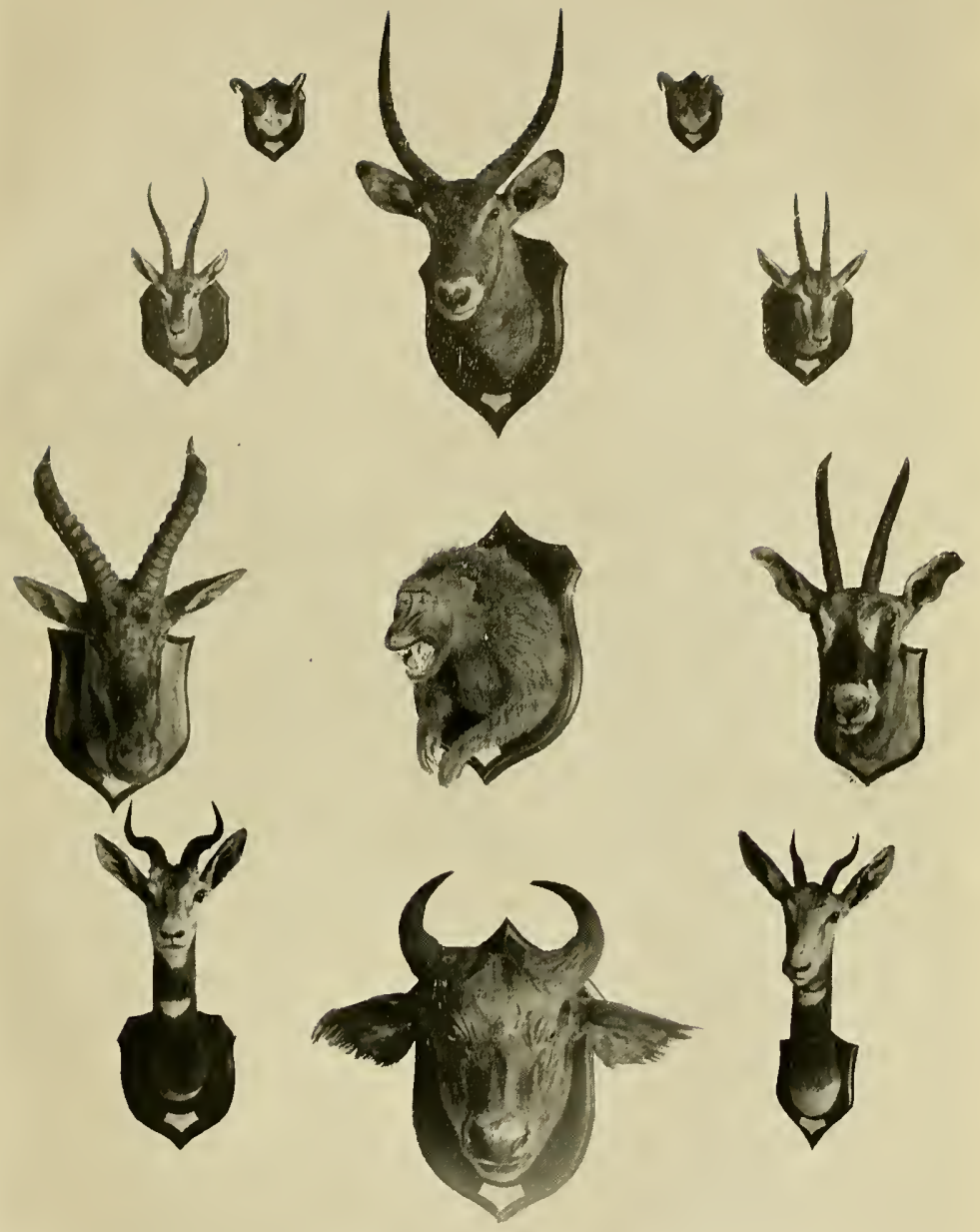

MORE TROPHIES. 



\section{BAUCHI}

Mr. F. "Well, I am not quite with you there: I should be inclined to call it

MYSELF (thinking I am on a winner). "Exactly. Generous without being potent."

Mr. F. "There again, I think if we were to say mellow -. Now, thirty years ago ...."

LAws (very bored). "Is it Canary, or palm-wine, anyway?" (Cries of "Order! Order!")

Laws had a theory that a meal at midday brought on indigestion, and used to give lunch a miss; till one day I found him eating chocolates in his cabin at 3 p.m., whereat he had to confess that indigestion was preferable to the pangs of hunger, and after that used to join us!

We made Plymouth in June 1910, the day after the running of the Epsom Derby, which had been won, we learnt from the pilot, by Lemberg, which horse I had drawn in the ship sweepstake. And "so home, to my great content." 


\section{CHAPTER V}

\section{NARAGUTA}

IN the middle of November 1910, accompanied by "Piccin," but leaving old "Peg" behind, I sailed on my second venture by the Burutu (Captain Potter). As we left the dock in the usual Liverpool snowstorm, I felt little more cheerful than I had done two years previously.

A mutual interest in a Ruff's Guide, from which I was endeavouring to extract comfort during the miseries of the Bay, hastened my acquaintance with John Radcliffe, whom I now met for the first time. We were to forgather later under much happier auspices at Ascot.

Another fellow-traveller was one Cockburn, better known as "Rustibuckle," a well-known old joker on the Coast, who regaled us with his exploits in those regions from morning till night. $\mathrm{He}$ is credited with having, when dunned by a Coast solicitor, shouted: "Oh! my wife and children!" dived overboard, emerged from under the opposite side of the ship, and safely hidden himself in a coal lighter, till the legal gentleman had departed, assuming the defendant's death.

Dick Bracken also was on board, and kept himself in good spirits in the Bay by recounting to me ghastly tales of the sea, and playfully drawing 
my attention to a falling barometer, well knowing that I regarded the mere fact of being at sea at all as a crisis in itself. Why is it, by the way, that the artistes at a ship's concert invariably elect to sing about death and wrecks and pale hands? And that the purser, when everyone else is yawning and dying to get away, must come forward and sing a dirge of seven verses "by special request?" Which reminds me of a very tough miner I once travelled with, who spoke seldom, but always to the point.

A jejune-looking missionary lady was squeaking out the somewhat stale information that "There was a green hill far away."

"Well," commented he of the mines, "her husband won't be waking her up in bed to sing to him!"

After a voyage on the Empire as far as Lokoja, I received orders to report at Naraguta, travelling viâ Baro and railhead, much to my disgust, as I had hoped to go viâ Ibi, and get some good shooting. About this time some great mind had conceived the idea that it would be salutary for junior officers loafing in the provinces to be brought into touch with the Heads of Department (who did the real work, of course) at Zungeru. Accordingly, on arrival at Baro, Backwell and I were diverted by telegram to the capital, to be, as it were, presented at Court.

Having duly introduced ourselves to the Chief Secretary, we were instructed to call upon the Chief Justice, the Principal Medical Officer, the Attorney-General (I trust I have given them 
their small-chop order of seniority), and, later on, the new Governor, Sir Henry Hesketh Joudou Bell, K.C.M.G. Why the Treasurer, the Postmaster-General, and the Officer Commanding Troops were omitted from this list of celebrities, we were neither informed, nor did we inquire. Not ours to reason why. These ceremonial visits were duly carried out. The P.M.O. ${ }^{1}$ commonly known-whether on onomatopæic principles or on account of his optimism, I know not-as "Tombstone," was as pleased with our visitation as we were with our two-mile walk, on about the hottest day of the year, to his bungalow on the hill. I fancy he thought we were patients who did not know any better.

The interview with the Governor concluded, and having been presented with three different sets of warrants by the Cant. Mag., the Chief Transport Officer, and Public Works Department respectively, for a train which did not run, we were permitted to depart to our respective duties, chastened by our intercourse with the Great. These pilgrimages by "mere people" to the political Mecca were very soon, I believe, discontinued-possibly because they were found to be waste of that almost unlimited commodity, Government time.

Having, as mentioned above, paid one futile visit to the station, we tried our luck again next day, and were successful in finding a Minna-bound train under steam. The stationmaster, his face swathed in bandages, and strumming "Rock of ${ }^{1}$ Dr. Thompstone. 
Ages" on a guitar, informed us that he thought this was a pay-train, and that we could not possibly travel by it. But we decided that, possession being nine points, etc., we would board it, and that the authorities could eject us if necessary. This proved successful, and by nightfall we had completed the long run of thirty-eight miles, thus maintaining the best traditions of that illustrious railway.

At Minna I encountered Herepath, who was almost in hysterics, having waited from 6 a.m. till 8 p.m. for our engine to take his horse-box to a siding and unload. He was now told it was too late!

Next day I reached Rigachikun, which was then railhead, and was there entertained to claret and cobras by Montague Porch, whose hobby at the time was to have his luncheon-table surrounded by deadly snakes.

In an endeavour to do a double march from here, to avoid the entourage of the Governor, who was also proceeding to Naraguta, I got separated from my carriers, and was stranded for the night near Bongo Dorina without bed, food, or water. Two belated carriers had followed me with loads, one containing bars of soap, the other burgundy. I drank a bottle of the latter, and then tried to get what sleep I could lying on the two boxes, covered with my rain-coat. A miserable night, with no protection from the mosquitoes; and it was not till noon the next day that I hit off my convoy again.

I spent Christmas alone at Rahamma, and 
ran into the Governor's crowd next day at roadhead. Here I met Stobart, who had been a contemporary of mine at Winchester and a fellow-student with me in the "Doidge's" division of Horace and Aeschylus's Persae. How different from those the Horace and Percy of our present circumstance! Fox was in charge of the escort, and Jimmy Finch, when his duties as croupier-in-chief to any passerby who cared for a fling at Freeze-out, or Chemmy, or other empire-building undertaking of the sort permitted, was supervising the clearing of the Rigachikun-Naraguta road.

These were cheery days during the tin boom. One seemed to be living in an irresponsible Bohemia, taking things as they came, unheeding of the future. As an example of the spirit of the times, LangslowCock recalls the accomplishment of the eccentric Waugh, who, having ridden from Liruein Kano to Naraguta in twenty-four hours, and possessing only the things he stood up in, invited the entire station to dine with him. Over that dinner (provided in toto, cook included, by the guests) presided the host-unabashed, and clad in Stobart's pyjamas! Waugh had recently got into queer street for his drastic treatment of a certain village under the impression that he was beleaguered by several thousands of Pagans. The "siege" was "raised" by Gerald Uniacke. "I had intended," the latter subsequently told me with twinkling eye, "to take four dogarai with me," but I finally decided, in view of the gravity of the venture, to take six, fully armed with turbans and sticks!" 
Finch, with whom I stayed the night, was in great form. He asked me, after an exhaustive inquiry into the state of the Turf and the form of the "back-end" handicappers when I left England, what job I was taking over in the province. I replied that I thought I should be working in the Sarkin Yaki's District.

"But that's my district, isn't it ?" said Finch. "Well, I presume you know best about that!" I remarked.

"No," replied Finch, "Sarkin Yaki will know best: we will send for him, and ask him" (!).

An anecdote or two about mine host will further help the reader to appreciate the fact that Wild Thompson, with all his resource and wit, had indeed "struck a snag" at Loko."

Finch had travelled up-country with a number of very green youths, hereafter known as the Boy Scouts, fresh, most of them, from the School of Mines. He impressed upon them at Rigachikun the dangers of the road, and volunteered, as an old hand, to divide them each night into watches. The watches were duly allocated, Finch arranging to take the final one from 4 to 6 a.m., when the party would hit the trail, as they say out West. "Now, boys," said the old stager, "keep a good watch, and whoever is on duty from 2 to 4 need not call me. I am used to these watches, and shall wake automatically." And so, night after night, these youths took their turn till 4 a.m., when, true to orders, the last relay turned in, while master James continued to hog it till dawn!

1 Vide Chapter IV. 
The story of the fortification of the "Valiant" is of course a well-known one: but in this case our friend, by over-acting his part, was hoist with his own petard. Affecting to have been hit by a poisoned arrow, he faintly appealed for whisky and soda. Here his fellow-conspirators sympathetically but firmly replied: "No, no, old thing! Whisky would be fatal. No whisky to-night!"

A year or two afterwards, Finch was ordered to take over Pankshin, the headquarters of the Pagan Division, "Now, mind you!" were his parting words to his friends, "I'm not going near those ruddy Pagans!"

In the early days in Bornu, Finch had been in charge of the Provincial Office, and used to work at a table side by side with the Resident, Mr. Hewby, who, being a man of few words, would give the simplest order in writing, thus: "Mr. A. R. Finch. Please hear this case," and so on. Finch could not fathom the "A.R." part of it (which stood of course for Assistant Resident), and one day, in desperation, he returned the chit with "A.R." erased, and "J.R." heavily underlined, substituted in its stead!

To this same office came a clerk one day of the super-educated, must-do-the-proper-thing type, and told Finch that he proposed to christen his newborn son and heir "Silvanus." "Most suitable," replied Finch, "it means "bushman." "

He later introduced a pack of beagles and foxhounds to the Plateau, and used to hunt them with as much pomp as if it had been the Cottes- 
more. One day an ostrich was the quarry, and hounds soon took a strong line, and disappeared from view. Oaths and expletives gushed from the Master's lips (we were always afraid that he would have apoplexy on these occasions), as he informed the field that they had changed on to a hare, "he knew dam well." They had changed the line-not, however, in favour of a hare, but Langslow-Cock's ham, which they were found eating in the pantry with the utmost relish !

So much for this distinguished Political Officer, whom I must leave for the moment, paying out threepences beneath a large white umbrella bearing in bold block letters the legend: STOLEN FROM J. Finch.

My arrival at Naraguta was far from auspicious. The accommodation for the Political staff under normal circumstances was entirely inadequate, and the arrival of His Excellency made things worse than ever. My billet was a small tree, under which I was stranded till 6 p.m. with my seventy odd loads, till a miner took pity on me and let me share his hut.

Dr. Gordon Hall, the Senior Medical Officer, was billeted on Bourke, now manager of the old Niger Company Mine, taken over by the Naraguta Tin Company, and there he remained for the next two months.

The housing of Government officials was the laughing-stock of the mining fraternity. The natives, too, who are quick at drawing conclusions, could not reconcile the miner lording it in a palatial residence with the "Judge" pigging 
it in a hut scarcely adequate for a horse or fowls.

"Where is the Court sitting?" a miner inquired one day.

"This is the Court," I replied with as much dignity as I could assume from the magisterial packing case, which did duty as a chair, while the pigeons dropped their souvenirs on the table. "No, seriously, where is the Court?" he went on. I murmured something facetious about the Central Criminal Court being closed for repairs, but the position was really rather invidious.

My very first duty - the morning, in fact, after my arrival-was an unpleasant one. It was to execute a search-warrant on a European suspected of doing away with $£ 200$ of silver, part of a consignment of specie he was bringing up-country for a certain mining. company. Any qualms I had, however, were at once put to rest by the suspect himself, who complacently handed me the keys, adding: "Would you like the cook to help you search? I've hunted myself, and can find nothing"! I, of course, found nothing either, but it seems fairly certain from what transpired afterwards, that he had sent the cash home by an accomplice (who, when the time came, declined to disgorge!). Anyhow, he took his instant dismissal from his employers without turning a hair.

During the visit of His Excellency, John Radcliffe, who was doing chauffeur, bought from Stobart a likely-looking black horse, with a view to the coming Lagos races. He was a bad-tempered brute, with an incorrigible trick of rearing. With- 
out rhyme or reason he would get up on his hind legs, and often come over backwards.

Having been dependent, when at Oxford, for my riding on such mounts as my friends-not entirely from charitable motives-were kind enough to give me, I had perforce accustomed myself to some very remarkable conveyances. One I remember used to sit doren on the tram-lines at Carfax. Another would take its stance on Port Meadow and refuse to budge. (Ben Birbeck sat for a whole day on it once reading the Sportsman and smoking cigars.) Being accustomed therefore to rough rides at home, and my nerve, moreover, being better then than it is now, I offered to take care of this animal, whom we christened "Satan," till John left, and, incidentally, to try and break him of his vice. He was like a mad thing in his stable, and you could not get near him even to mount. I used to have to blindfold him, and then be thrown on to his back at a favourable moment. This, however, once accomplished, he used to behave like a lamb, and I never had the slightest trouble with him. In this respect he reminded me of a brute called "Lord Advocate," which I used to ride in the various 'Varsity steeplechases. His lordship was literally unmanageable in the paddock, and it would take half an hour to get on his back. One day, however, it occurred. to me that it might be the racing colours which irritated him, and I threw a great-coat over them. He instantly became sheep-like in his placidity. I was therefore able to assure John, not without a certain amount of self-congratulation, that the 
horse had got over this particular bad habit. John was not so sanguine.

I had been told off to accompany His Excellency back to roadhead, and in the afternoon we all turned out in our glad rags to join in the procession as far as the station boundary. John had asked me to ride "Satan," which I did, and all went well till young Sydney Kay, who had started late for the show, came tearing up behind, and, in doing so, barged into "Satan." From that moment he became uncontrollable, and acted up to his name. Getting up on his hind legs, he struck out with his forefeet; jibbed; then up facing west, and down again facing east; and, hovering each time, as it were, on a pivot, in uncertainty whether he would land on his feet or on his back, repeated the performance thirty times at least in about as many seconds. I have never before or since ${ }^{1}$ ridden such a fiend.

At first I dropped the reins, and leaned forward along his neck to preserve the brute's balance which was every time in jeopardy-for I have never known a horse go up straighter without " coming over." Then, losing my temper, I struck him again and again between the ears, till my whip broke; and finally I had to shout to Frankie Burton, the Governor's A.D.C., to ask His Excellency whether I might get on ahead. To this he agreed with alacrity, being as nervous about horses as he was about himself; and we went off on a mad career which never stopped

1 I must withdraw this observation. I have since had a little affair with a horse called "Trifle." 
till we got into camp, both in a lather of a sweat.

At dinner that night the Governor was kind enough to congratulate me on not having parted company with my mount: but his first question next morning was : "Frankie, where is that terrible horse?" I had already considered it wise to go forward very early on the "terrible horse" to the next camp. Here I handed "Satan" over to John Radcliffe, wishing him joy of the brute, and returned to Naraguta. He afterwards told me that he had got a worm of huge dimensions out of the poor devil, which no doubt accounted largely for his vagaries. "Black Arrow," Mr. Hall Walker's great horse, used one day to win his race by a street, and another finish down the course, and the public generally condemned him as a rogue-though his owner maintained from the first that there must be something organically wrong with him. I heard the true explanation some years ago from a man I shared a fly with to Hurst Park Races. He told me that his brother had made a post-mortem on "Black Arrow," and discovered that the horse only had one small lung (which my informant had had preserved in a bottle as a curio). So that, far from being a rogue, he was probably the gamest horse that ever lived. Curiously enough, I have before me an extract from "Rapier's Notes," which reads as follows :-

I have not heard what caused "Irish Mail's" death. Possibly he had long suffered from some ailment which would have accounted for the various disappointments 
he occasioned if one had known of it. Horses are sometimes blamed for shiftiness when the cause of their failures is physical disability or infirmity.

Colonel (now General) Cunliffe took him over from John, and started to train him for various races at Lagos. Within the first few days, however, he fell to savaging his groom in such an alarming manner that Cunliffe was constrained to seize the first weapon that came to his hand, which happened to be a polo boot, and biff "Satan" over the head with it, unfortunately fatally damaging one eye. "Satan had a little fit of temper the other day," he wrote to John-or words to that effect-" for which I had to chastise him. He is now fit and well-but will run under the name of 'Cyclops' "' (!).

It had now been settled to shift headquarters from Bauchi to Naraguta, and I was detailed, besides carrying on the office as best I could, to supervise the building of the new station on the site selected, a bleak hill about a mile from where I was living. The type of houses chosen was unsuitable, being far too clumsy and full of doors and windows, and I came in for a good deal of chaff from my mining friends as they passed of a morning. "Good morning, Mr. Heath Robinson!" "Ah! That's the idea! If the rain blows in at the front, it blows out at the back!" "You've forgotten to put a window in the roof, haven't you ?" were among the many quips I had thrown at me, as I walked gloomily about with my one skilled artisan, facetiously known as "the other 
mason." But I did not mind this, as I was only acting on instructions, and was not the architect. Moreover, profiting by the defects in these buildings, I managed, when the time came, to make a very nice little shanty for myself.

Jaunts out to Tin Areas, the Anglo-Continental property, Bourke's hospitable mine, and the Niger Company's palace at Tudun Wada, all helped to make up for the worry and overwork involved in trying to carry on practically singlehanded in the office, and also do "foreman of works" on the new station. When I compared the work I was doing, and the pittance I was drawing, with the life of ease led by the numerous gentlemen who drew anything from $£ 60$ to $£ 110$ per month, and knew as much about tin as I did, it made me melancholy. One weird bird, who used to gallop about in a red shirt, vouchsafed us the information, when slightly in his cups, that his syndicate had sent him out to prospect for the "bacilli" of tin!

In March, I think it was, considerable fuss was made over the tour through these parts of the unctuous E. D. Morel. His path-I could never make out why-was strewn with roses, and he was lavishly entertained wherever he went. $\mathrm{He}$ got a home-truth or two, however, from one individual, a foreman on the road-construction, who observed to him with refreshing candour: "Well, now, let's get down to it, Mr. Morel; I suppose you're out 'ere on the make same as most of us ?" He of course wrote the inevitable book: this has become almost a solemn obligation on 
anyone who has roamed the high-roads of Nigeria for a few weeks.

At length the Staff, offices, etc., and last but not least Gordon Hall (!), were safely established in their respective leaking quarters on the hill. No sooner was this effected than Mr. Gowers was posted to the province, and arrived almost simultaneously with the Acting Governor, Mr. Temple, C.M.G., on tour. And then Gowers called for the Bukuru files! Now, during the mining influx, change of stations, and general pandemonium, I am afraid these archives had been sadly neglected. Enter Stobart into my shanty, in a state of consternation, and carrying a box containing-white ants! "Shall I tell him that-_" he began. "Had it been anyone else but Gowers," I chipped in, "I am afraid I should have given you some very immoral advice! But from what I know of him, the truth will be, on the whole, the least dangerous course!" And it was -accused getting off with an admonition.

A race-meeting was held in the Governor's honour. Finch won the first four races off the reel on two horses of Gowers'. He was a bit late getting to the post for the fifth, and in cantering down his horse put his foot in a hole, and gave Finch a toss. We were all lined up on fidgeting horses, chafing to be off, when Finch, standing in front of us, elected to give us an address on his misfortune. Being on the Governor's horse, who was now showing signs of temper, I shouted : "Cut all that out, for God's sake, Finch ! and let's get started!" But, as the flag dropped, my 
unruly chestnut, instead of going forward with the rest, backed slowly towards the prospecting pits near Bourke's yard, and took no part in the race, which was won by another chestnut. The winner was at first mistaken for the Governor's animal, and he came in for some premature congratulations as a consequence, whilc I still hovered over the catacombs!

In the Open Native Race, Finch's small boy came in a good second, and attributed his narrow defeat to having lost his whip at the critical moment. "Rot!" said James to the hapless youth, "what the devil should you want a whip for?" Five minutes afterwards someone twitted Finch for losing the fifth race by a neck. "Damn it!" he replied indignantly, "couldn't you see I had dropped my bl-st-d whip!"

Next evening I gave a sort of house-warmer in my new shanty on the hill. "Lawyer" Berkeley, Fox, Finch, Dix, Stobart, Radcliffe, and Dick Corfield ${ }^{1}$ made up the party; and the conversation developed into a heated controversy on racing topics. Arguments were freely raised as to what was first, second, and third, in such and such a race in such and such a year ; bets were made on the coming "Liverpool": everybody backed his own knowledge against everybody else's : and, in the rare pauses for breath, Finch was heard droning that " he didn't care: he knew 'Drogheda' had won in ' 97 , because he was on his way home at the time from Egypt"; as further "proof" "he had

1 For his life vide Richard Corfield of Somaliland, by Prevost Battersby. 


\section{A DINNER-PARTY, AND A BURGLARY}

been left a 'parcel' by some relative that year, and had thrown a fruit jelly at the head of somebody he disliked, to show his independence." The party finally broke up, and, as Dix mounted his horse, still arguing some point or other, the beast got up on its hind legs, and Dix, not letting this trivial diversion interfere in the least with his oration, slid gently down its back, and continued the argument as if no interruption had occurred.

The "morning after the night before" I found the table littered with illegible chits purporting to record immense wagers, some won and lost, others hanging in the balance, and which I doubt being ever remembered by the contracting parties.

This same morning, feeling far from scholarly, I was examined and passed in the Lower Standard Hausa Final by His Excellency, who left with his Staff in the afternoon.

It cannot have been more than a day or two after this that I came to the office at about 8 a.m., and found that a box, which should have contained $£ 200$ in silver, had been removed from the strong-room, ${ }^{1}$ and $£ 27$ odd abstracted. The rifled box was lying on the window-sill of the office. The guard were arrested, and admitted that they had taken over sixteen boxes, whereas there were now only fifteen in the strong-room. I had on the night before the occurrence asked the O.C. Troops, in the usual way, to "relieve the present guard," but, by an oversight, he had replaced them with a single, instead of a double guard. Having technically neglected the Govern-

1 A mud building without a door! 
ment Standing Order, which lays down that "the officer applying for a guard must satisfy himself that the correct guard has been supplied" or words to that effect, I was called upon to make good the money. The guard, on the other hand, who were obviously concerned in the robbery, and were sentenced by a court of inquiry to various terms of imprisonment, were subsequently granted King's pardon on Coronation Day. So that was that: or, Latiné redditum, Sors Nigeriana.

Gall ${ }^{1}$ now took over the province, just as the excess of demand over supply of grain, created by the huge influx of mining labourers, boys, and camp-followers from other provinces, was beginning to create an acute situation verging on famine.

This class of native were all dependent on guineacorn as their staple diet, while the Pagans only cultivated "atcha," and only enough for themselves at that. Guinea-corn had therefore to be imported by the hundreds of tons from Sokoto, Kano, Bauchi, and elsewhere. I had a constant stream of camels, bullocks, and donkeys coming and going, which had to be subsisted, and have their burdens weighed; and more often than not I would be working up to eight and nine o'clock at night, in order to keep abreast of the consignments, and not delay the unfortunate owners, who did not relish these trips to the cold and rainy Plateau, apart from the mortality among their stock.

Large batches of these wretches had been dispatched by Gerald Uniacke from Liruein Kano.

1 Died 1920. 


\section{THE ROUGH AND THE SMOOTH}

In reply to a memo of mine making various suggestions for their comfort on the next trip, and giving details of final payments due on their return, I received a letter, heavily edged with black, containing three words : "They never return."

But it is only fair to say that the managers of the various mines would always make things easy for me, and assist me in every way. Langley, of the Niger Company, and Crichton out Juga way were particularly helpful to me, when I found myself landed with more grain than I could dispose of. Had it not been for this-and I think I can honestly say that I never had an unpleasant word with any " tin-opener" I came in contact withthe work would have been quite beyond one man. Bills of exchange, deposit accounts, cheques, etc., all helped to complicate and increase the work of the local sub-treasury. As it was, the cheery company and good-natured banter of people who did not take life too seriously rubbed the rough edges off one's difficulties. "Don't let me disturb you," said Kent, dropping in one day. "My business won't take five minutes : I only just want you to give this watchman of mine a couple of years, and cash me a draft for fifty quid." 1

On the Coronation Day already alluded to, a guard of honour turned out under Bobbie Ellis; and Colonel Judd, a very military and patriotic gentleman, decked in full regimentals, took the salute. Gall had all the Europeans up to his house after the cercmony, and entertained them

1 The Government cashed the cheques of a miner long before it took a similar risk with its own officers! 
very generously. I learned from one miner that he, in common with many others, was labouring under the delusion that all Government officials drew an entertaining allowance, and that cven the smallest of small-chop parties was charged up to that fund! Certainly if ever there was a case where such an allowance would have been really justified, it was in the ease of the Resident Naraguta of that day.

A race-mecting of sorts was held in the afternoon, but the principal affair was a luncheon at the "Club." I fancy it was after this banquet that dear old Walter Wethered, intending to down a glass of crême-de-menthe, inadvertently picked up a glass containing toothpicks, took a gulp, turned blue, and nearly choked!

At about four o'clock a thunderstorm broke with terrific violence (probably part of the same great storm which swept Epsom Downs about then, causing several fatalities among the Summes: Meeting crowd), and that good sportsman Judd and I were riding back up the hill, when a hideous Hash of lightning, followed by a thunderclap of corresponding immensity, blinded me for the moment, and drove iny horse nearly mad. When I looked round Judd was on the ground. Whether his horse had shied at the thunder and deposited him on mother earth, or whether the festivities of the "Club" were beginning to react upon the gallant Colonel, I do not know; but with great presence of mind I ran him in to Grordon Hall's house, tactfully saying: "A brandy and soda for the Colonel! He has becn struck by light- 
ning!" Having partaken of this restorative, the patient went to his house and retired to bed.

That night the Colonel had invited a large party to dinner and cards, and a case of champagne had been duly laid in for the occasion. Allured by the convivial clatter of knives and forks and the popping of corks, he rose from his sick-bed and announced that he felt better.

"No, no!" cried a dozen voices, "you must lie down, Colonel! We appreciate your distress at not being able to perform the duties of host, but being struck by lightning is a serious thing!"

Judd retired again crestfallen, not without one eye having roved towards the spot where Jules Mumm, his Extra Dry, stood stacked in imposing array.

The evening wore on, and somebody called for a final bottle.

"None lib, sah!" the boy replied. "All done finish!"

"But I've counted them, and I knoro there's one left!" cried the thirsty one.

A search-warrant, so to speak, was forthwith issued, and the premises scoured, with the result that the missing wee bottle was discovered, empty and its earthly task performed, beneath the Colonel's bed!

The following day Kent, who had been staying with me for the festivities, returned to his mine, and I cracked up with fever. This grew worse, and I became very ill. I was in severe pain internally, but the most maddening feature of my malady was a headache which lasted continuously 
for nine days and nights, and defied all McKinney's tireless efforts to defeat it. I cannot help thinking that the lightning may have had something to do with it-for I certainly felt very queer at the time-in which case I have perhaps treated the Colonel's mishap with undue levity! Be that as it may, I was invalided from Naraguta, having handed over to Wightwick, and left about the middle of July.

I was not altogether sorry, for the overwork was beginning to tell, and I felt ready for a rest, though I had only done seven months. Foulkes, who had been transferred to that province, accompanied me as far as Zaria, where I entrained, and proceeded to Burutu, viâ Baro and Lokoja, on the Valiant. George Browne, in the Political, and J. O. Greenwood, in the Police, familiarly styled "Jog," were also en route home, and sailed with me on the Burutu (Captain Potter) from Forcados.

Jog was a weird fellow, and very powerful. $\mathrm{He}$ had done most things, and been to most places. He could quote from Gladstone ${ }^{1}$ and Chamberlain by the yard, and, beneath a rough and devilmay-care exterior, he concealed a great deal of character, wit, and conversance with literature. $\mathrm{He}$ was alternately maudlin and brimming over with exuberance.

1 Especially the passage on Ireland, which he would recite with gestures: "What we wish is that where there has been despair there shall be hope (high note), where there has been distrust there shall be confidence, where there has been alienation and hate (deep bass) we shall have sown the seeds of deep affection between man and man!" 
Browne shared a cabin with him, and used to report progress to me at breakfast.

"How is Jog to-day?" I would ask.

"Quite cheerful this morning: says he thinks he will live through the voyage!"

Another time :

"A relapse this morning: he has a large gingerale in one hand, while, with the other over his heart, he is announcing his approaching dissolution!"

Then Jog would appear, and indignantly declare that he was going to report his steward to the skipper. He had apparently rung the bell for the former and informed him gravely that he was dying; whereupon the steward had equally gravely handed him the-well, something quite irrelevant!

George Browne would periodically be awakened by a sock-suspender being dangled over his nose from the top bunk to the stentorian accompaniment of "And a half seven! No sounding!"

Poor Jog! He went to Strathpeffer that leave, never to come South again.

"My mates are a poor, funereal lot," he wrote me a fortnight before he died. "I pass among them with here a quip from Gladstone, and there one of my own drawing-room tales, but fail to raise a smile, though they are most of them a lung better off than I am."

We could do with a few more of that sort out here-superior to the conventions of life, and ready to welcome death with a jest on his lips. 


\section{CHAPTER VI}

\section{BORNU}

New Year's DaY 1912 saw me once again accompanied by the faithful "Piccin," trailing with reluctant step up the gangway of the Nigeria (Captain Davis). My cabin had earned previous distinction, having been occupied by Joe Chamberlain at the Coronation Review at Spithead in 1901. My usual gloom was in no way dispelled when, on the fringe of the Bay, the good ship developed "engine trouble," and on two occasions we were adrift with "Out of Control" signals flying. But, as Jimmy Somerville said, it " all counted towards pension."

At Lagos I received orders for Nassarawa, to which province I omitted in the last chapter to mention I had been instructed to transfer just prior to my illness at Naraguta. With Gordon Hall I proceeded on the Sultan to Lokoja, where I had the pleasure of meeting Brocklebank.

"B-bank," as he was generally called, had been in the W.A.F.F.'s and also the Political Service, and was now a director of the London Kano Trading Company. It had been in his mind for some time to start a paper somewhat, as far as I can remember, on the lines of West Africa-that journal founded later on, and so ably edited by 
Mr. Cartwright. The offices and plant were to be erected at Lokoja, and he selected, or was going to select, a site the day I left. He did me the honour of asking me to consider undertaking the editorship. I did give the matter considerable reflection, as this sort of work has always appealed to me ever since my novitiate at a guinea per thousand words on the staff of a certain tangerine-hued journal, but the idea never materialized.

On arrival in the Osprey at Loko, I received a wire from Major Larrymore, Resident of Nassarawa Province, telling me that $I$ had been diverted to Bornu, and advising me to proceed overland viâ Bauchi. The General, enfin, had been as good as his word, for he had always promised to get me up to Bornu if he could.

On a rag of a horse-the only one I could hireI set forth on a trek which was to take thirty-seven days, practically slap across the Protectorate from south-west to north-east. "Piccin" accomplished this journey, as had her mother from Ibi to Bauchi, in a box. The tedious pilgrimage had this merit, that at intervals of every four days one passed through a Government station of some sort, viz. Keffi, Jemaa, Bukuru, and Naraguta, Bauchi, Gombe, Nafada, and Gujba. ${ }^{1}$

At Keffi I made the acquaintance of Parsons, the M.O., whom I promised to send some notes on building, based on my unhappy experiences recounted in the last chapter (!) for a book he was compiling. ${ }^{2}$

1 Vide map. $\quad 2$ A Hausa Phrase-Boole (Humphrey Milford). 
Thence, viâ Jemaa, to Bukuru, where I burst n upon a riotous board being held by Stobart, Wightwick, Dix, and Finch-the last-named with his head shaved and almost enveloped in a huge stick-up collar, which rendered him grotesque.

At Naraguta I picked up my old grey horse of last tour, and passed on to Bauchi, and thence to Gombe, where I found Lonsdale.

He had arranged to smoke a leopard out of its lair that evening, but though we spent an hour there waiting with guns in hand, the leopard did not, as they say of rent in the Political Memoranda, "emerge."

Crossing the Gongola, I pursued my hot journey to Nafada, where I picked up a hunterman, who accompanied me for the rest of the way to Maiduguri. Again I could not resist the temptation to combine shooting with trekking, and though I did secure a decent male roan, it was all I got, and I had to pay for it with a severe go of dysentery. I disregarded this for some time, but at Limlin I collapsed and could go no further. I wrote to the General, asking him to send out a hammock.

A weird youth, answering-more or less-to the name of Sainsbury, who was at Jajel, intercepted my note, and galloped out to visit me. He was too much preoccupied with the record time in which his horse had completed the eighteen miles to be seriously interested in my illness. A whirlwind youth, who had done, at the age of twentythree, what nobody but a superman could have accomplished in under forty-four years. For this 
reason I hesitate to attempt to set forth a complete list of his achievements lest I fail to do him full justice. Among other things, however, he could shoot crown-birds on the wing with his revolver: he had walked, on dry land, across the Alo Lake in August; and had been told off specially, when cattle-ranching in Australia, to sit astride the stockade and shoot any wild horse that showed signs of so much as laying one ear back stone dead through the forehead. ${ }^{1}$

It was no doubt the echo of those days out West which prompted him, at the annual board on cash and stamps, to have his office surrounded by a W.A.F.F. guard, and sit at his table with revolver cocked, and ready for the slightest sign of outside interference.

His treatise on horse-breeding in Bornu would have been immortal had the authorities appreciated it sufficiently to have it published. The province was indeed lucky to enjoy the services of so versatile an officer.

Sainsbury left that evening, and, about midnight, just as I was getting off to sleep under the soothing influence of opium, Dr. Thompson arrived. This, in itself, annoyed me, but when he removed the indignant "Piccin" from her chair at my side, I fear I became rude. The climax was reached when he insisted on taking me right through to Maiduguri, instead of heeding my fervent entreaties for a halt at Jajel. I am afraid I sulked, and barely deigned to reply to his

1 Thus, times without number, saving the life of the attendant engaged in handling the brutes inside the stockades. 
periodical inquiries as to how $I$ felt. We have often laughed about it since, for we were very soon to become firm and intimate friends.

The General was very seedy at the time, and it was not till several days later, when I was myself more or less recovered, that I paid him a call. I have already described this charming man. He told me that he was putting me on to Assessment work under W. B. Thomson, ${ }^{1}$ as delightful a Scotsman as the General was Irishman.

"Tamsie," as we called him, had been collecting a mass of invaluable detail as to the respective incomes of the various classes of taxpayer, classifying and tabulating the information, and finally submitting a practical scheme for levying the income tax on a 10 per cent. basis. George Seccombe 2 ("Judgie Dumboa" 3), from whom I was to take over, had experimented with the scheme in certain districts, and this had been sanctioned, and was to become fully operative for the current year.

Mr. Hewby tells a story which will appeal to those who appreciated the General's blarney. Tamsie had submitted a valuable, but necessarily dry, list of the various incomes arrived at, and it was up to the General to make some recommendation as to each proposal. Having exhausted the

1 The Editor of West Africa has courteously allowed me to reproduce in Appendix $\mathbf{B}$ a (quite inadequate) appreciation of Tamsie which I wrote in that paper after his tragic loss on s.s. Umjeni.

2 Prisoner of war at the time of writing.

${ }^{3}$ So called because he was stationed for some time at Dumboa. 
usual "I concur," "Quite right," "I presume you have carefully verified this," etc., and becoming very bored with the pages of statistics it was necessary to comment upon, he at length came to an entry which he felt it would be safe to jump upon for a change. The entry was: "Gauta 1 ...10s." Opposite this the General minuted: "Seems high." Later on, in the course of taking over, Mr. Hewby came across these papers, and remarked: "Do you know what gauta is, General ?"

"Yeth," replied the General like lightning, "it workth out at ten bob."

"Do you know what gauta is?" repeated Hewby inexorably.

"Well," said the General, now at bay, "ath a matter of fact I don't !"

"Then what the devil do you say it seems high for?"

"Becauthe damned well it doeth theem high!" was the retort, which admitted of no further argument.

As another example of bluff I recall an occasion when the General, by way of airing an assumed familiarity with the new Land Registration Ordinance, which was then in its prime, Greek to most people, and entirely inapplicable to most provinces, inquired glibly of a number of Village Heads, who had brought their tax in: "Well, are they all well ?" Yes, they were all well, said interpreter Maina. "And all their people well ?" Yeth, all their prople were well. "And all got their Ther-

1 A native form of tomato. 


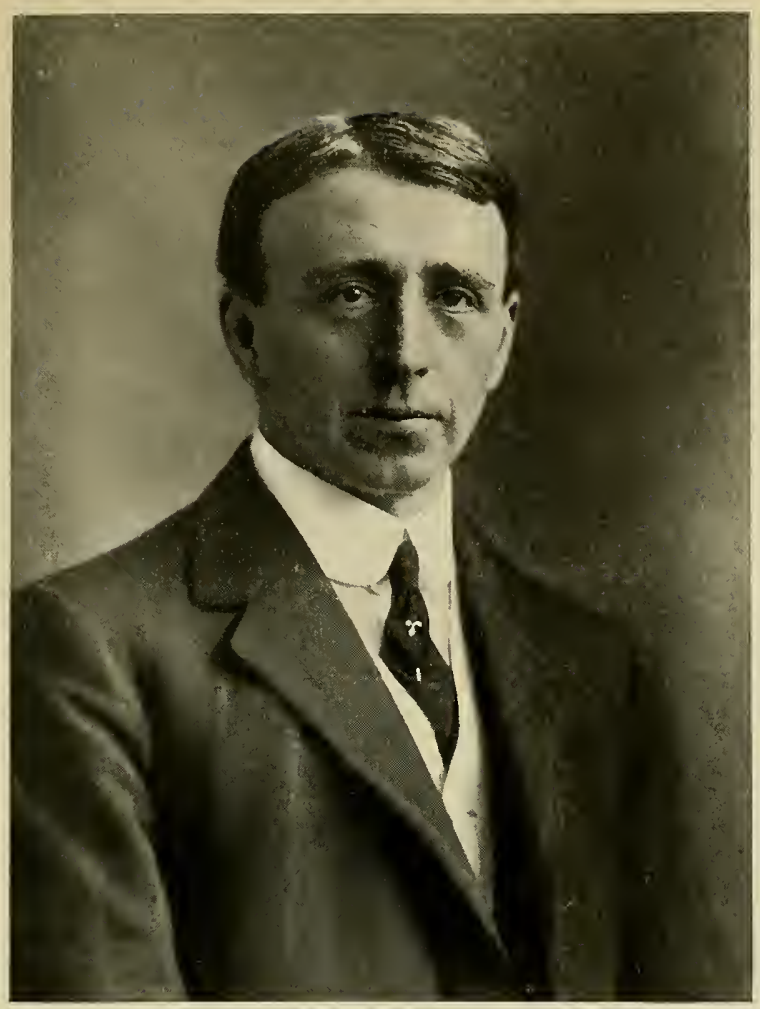

W. B. THOMSON.

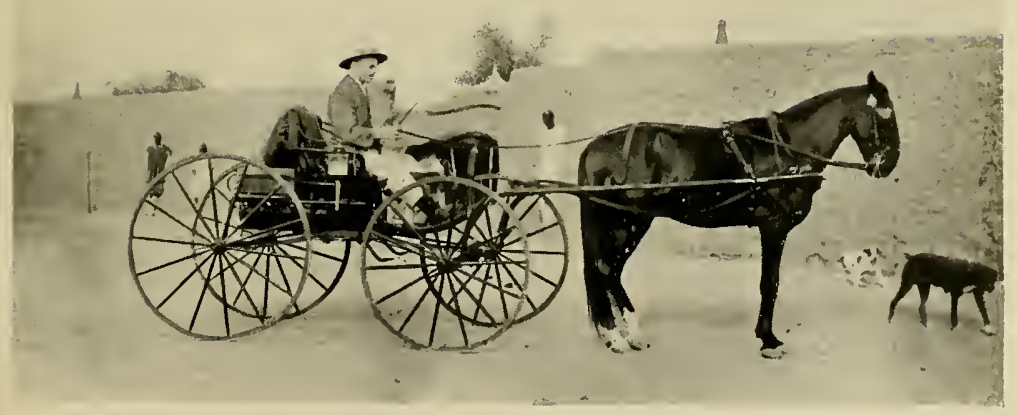



tificateth of Occupanthy ?"1(!) I furtively clutched the General's arm, and gently protested that this was rather premature. "Well, perhapth we will defer that quethtion till later on," he said magnanimously as he bade them good-bye-and that evening inquired of me: "What are thethe damned thertificateth, anyway?"

As a result of this drudgery of Thomson's, Bornu can probably claim to be the only province that paid as early as 1912-or ever paid, I think-the full estimated 10 per cent. income tax.

The next two months were like a nightmare to me. I was in a more or less chronic state of dysentery, the Bornu heat was at its zenith-the thermometer frequently registering $115^{\circ}$ in the shade-and the dust and flies unbearable. I have always maintained that these flies were the worst feature of Bornu. I remember one evening George, who had a four-wheeled buckboard and was a superb whip, taking me out for a drive to get a breath of air. We got "a breath of air" all right, but it was actually hotter than the surrounding atmosphere, and we had to turn back!

I was practically living on ipecac. and opium, and it seemed doubtful if I should weather a tour. The strangeness of the Kanuri people, language, and climate all tended to increase my nostalgia for Hausaland. A fan-boy was indispensable, and the General, during his attacks of asthma, used to employ two.

1 The Certificate of Occupancy has now practically superseded the Koran and the "Local Authority" Mahomet (vide Chapter X). 
In April, with the increasing heat, the General was seedy again, and eventually became seriously ill. One morning, at about 5.30 , being still on the sick list myself, his boy, Musa, put his great moon-shaped face in through my mosquito-net, and muttered: "My massa do walka foolish, and do talka foolish, and no man fit do nothing!" I hastened across to the General's bungalow in my pyjamas, and there found him fully dressed, but quite delirious, as the boy had attempted to explain. I had a desperate time with him till Thompson came across to my relief, and neither George nor I will ever forget the awful business it was in that sweltering heat, taking it in turn with the doctor to nurse him. He soon picked up, however, and was quite well again by the time his old W.A.F.F. friend, Colonel Strickland, ${ }^{1}$ arrived on a tour of inspection. The latter came to lunch with me, and expressed his views freely on the heat!

After many a cheery little dinner and sing-song on Tamsie's dulcitone, George went home, and Tamsie to Geidam; while, from now onwards, with few intervals, I spent my entire time eternally trekking, mapping, and assessing.

In May, Thompson, accompanied $\mathbf{K n o x}^{2}$ and Fairlie, ${ }^{3}$ both Captains in the W.A.F.F., on a patrol into the Burra country, and we were left without a doctor. I had almost immediately to leave assessing the Uje District and return to

1 Now Brigadier-General.

2 Reported missing in France.

3 Killed in France. 
the station, as Ash, ${ }^{1}$ the subaltern, was down with dysentery ${ }^{2}$ and Sainsbury with jaundice.

During this period I became very intimate with the General, who talked to me a great deal about his affairs. He had a rooted presentiment that he would not live to the age of fifty, and the uncertainty of his future movements after handing over to Hewby seemed to get on his mind and aggravate his depression.

He often used to send for me of an evening, and we would walk round the gaol, etc. The gaoler, Tokosi, was almost as great a character as the General. One evening, on the General asking his usual question as to the health and behaviour of the prisoners, Tokosi replied : "Except only Idirisu."

"And what'th the matter with him ?" queried the General.

"Well, sir, he practises wickedness too much!" said Tokosi, presumably meaning that he was out of hand.

"And he'th not the only one I know!" remarked the General, having a dig at Tokosi's partiality for " Old Tom."

"Please, sir," rejoined poor old Tokosi, "when you speak to me, I don't know whether to laugh or cry!"

The annual board on Prison Stores was always an event of grave anxiety and strain to Tokosi. One item : "Hanging Rope . . . nine yards," had

1 Killed in France.

2 Maiduguri's medical return of dysentery passed all previous records this year. 
been misread and entered from time immemorial by Tokosi as "Hanging Rope . . . nine years."

"But why nine years ?" I once asked him.

"Because," he replied in a dreadful state of muddle and the sweat pouring down his face, "it was entered in Major Ellis's time, nine years ago."

Three years later I asked the same question, and received the same reply!

The "Mark System" also presented great difficulties to Tokosi, who used to say with horror : "Oh, we can't have marks knocked off ; it would humbug the books too much. They must all have full marks."

About the middle of June the General left, the idea being that, having met and handed over to Mr. Hewby at Katagum, he should proceed to Naraguta. The meeting, however, was not destined to take place. On the day of his departure he had tea with me, and at six o'clock bade me good-bye. He was evidently suffering from great emotion, for the tears were in his eyes, and when Ash rode up, as if to accompany him part of the way, he waved him back, and calling out "God bless you all!" cantered away.

At Magumeri he became very ill, and there Moiser, who was on his way in to treat Sainsbury, found him. He got better, and as soon as he was fit to travel Moiser returned with him to the next camp, Busugua. Here he seemed comparatively well, ate a hearty meal, and went on ahead in the cool of the evening to Ngubala. Being apparently restless and uncomfortable with the journey, he halted at the market half way, and 

took-or rather thought he was taking-the drug he had been in the habit of swallowing for sleeplessness. Unhappily he took the wrong one, and by the time he reached Ngubala at 4 a.m. he was a dying man. He lingered on till 6 p.m., when he expired quite peacefully. During transitory flashes of consciousness his Irish humour did not desert him.

Through that long spell Moiser had one of the grimmest and most wearying vigils ${ }^{1}$ a man could well have; and now, on the top of this, he set himself, by trekking night and day incessantly, to bring the body into Maiduguri for burial. This he accomplished-four dreary stages-in thirtysix hours. Ash's fatigue party had prepared a grave in the little cemetery where lie Overweg, Boyd Alexander, and others who have given their lives to this sinister country. Ash gave him a military funeral. Benton, who had recently arrived, read the service as Senior Political Officer, and at the conclusion the General's own boy, Biri, an ex-bugler, sounded the Last Post. The spectacle was as impressive as it was sad. I shall never forget it.

A mural tablet was erected over the School in his memory by his many friends, inscribed as shown in the facsimile.

Benton having taken over the office from the Sainsbury youth, the latter was ordered to put in a month or two at Geidam, and then go on leave.

1 The full details of this sad occurrence, which it is not necessary to record, were given me both by Moiser and Bisalla, who is still with me. 
Having a number of private bullocks, or donkeys, at his disposal, this amiable young man pressed me to let him take home for me some of my shooting trophies, and so save me the trouble and expense of extra transport. There was no real necessity for this, but at length I surrendered to his solicitations, and handed over to him the skull and mask of the roan I had shot at Nafada, and which I valued rather highly. Ten months later, on arrival at Kano, en route home myself, Eric Douglas, of the London Kano Trading Company, informed me that there was a box lying in his store stamped with my name, which had been there for nearly a year. Did I know anything about it? I went and opened the box, and found it to contain the roan trophies, moth-eaten and ruined, which I had handed under pressure to my obliging friend to take home the previous June!

Mr. W. P. Hewby, C.M.G., reached Maiduguri at the end of the month, and, after assessing Masu and Magumeri Districts, I was called in to see him-for the first time. I do not presume to do justice to the portrayal of a man who came into the country before I came into the world and whose name ${ }^{1}$ was known even in the parts about Tripoli, but this much I will say : never did personality inspire greater loyalty or respect. His caustic tongue-and it could be caustic!-concealed the warmest of hearts; his bearing was formidable-almost arrogant-but only calculated

1 Having been at Ibi for some time in the Royal Niger Company days, his name was corrupted by the natives into "Mustafa" or "Mista Ibi." 


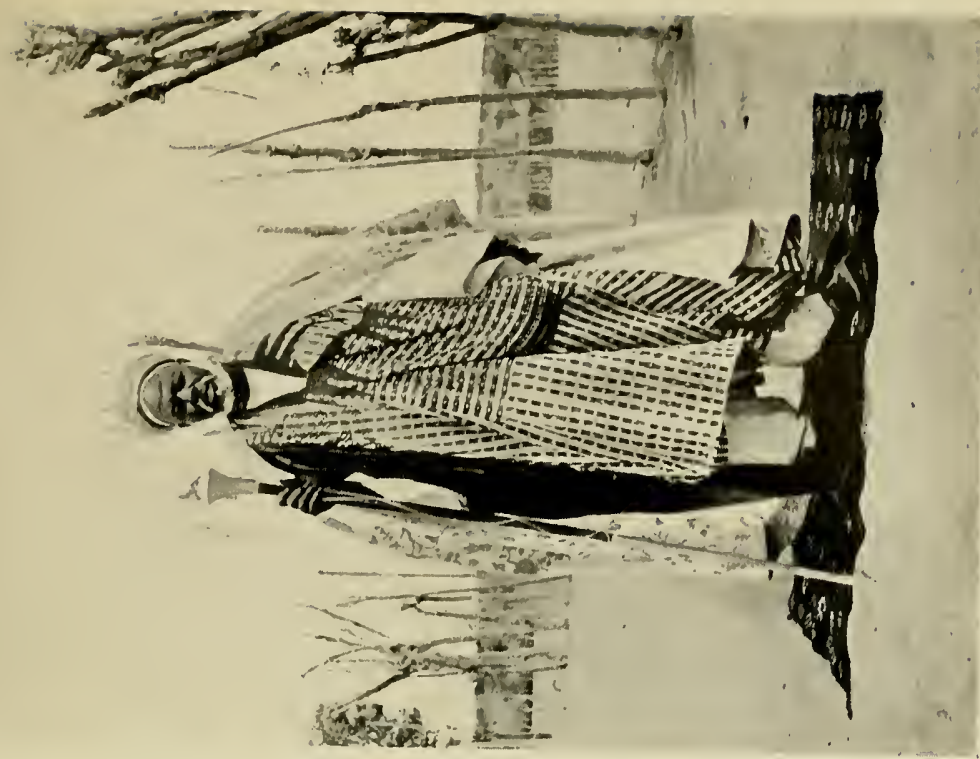

等

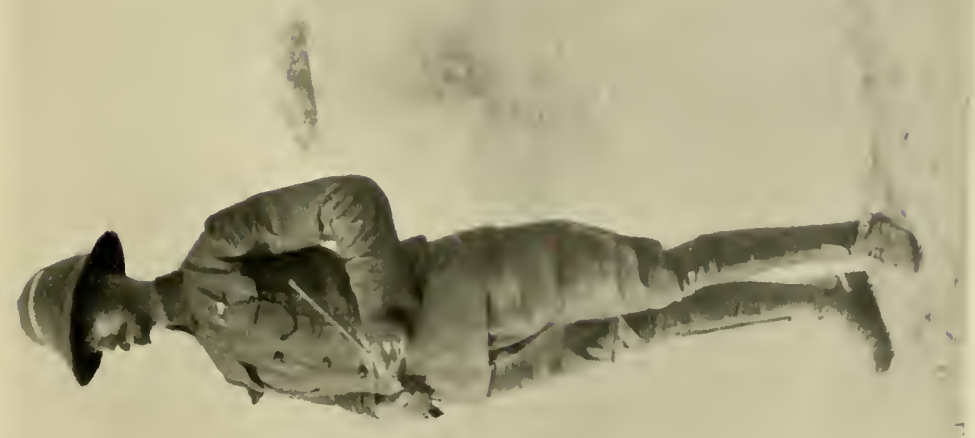

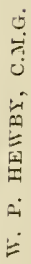



to discomfit those for whose consciences discomfiture was salubrious. I have never known him pay a direct compliment-it was not in his linebut he could convey his appreciation in a way which appealed to the instinct of the recipient as the encomia of a more unctuous personage could never have done. Palmam qui meruit ferat. Though to others it may be ordained some day to perfect the millennium in Bornu, with the elaboration of Ministerial Responsibility, an incorruptible Native Administration, and other respectable fetishes, those who were privileged to work under Mr. Hewby will never forget who it was who did the real spade-work.

It was only the other day that I learned from Mr. Hewby a little incident, the humour of which greatly pleases my fancy. The General had just arrived in Bornu for the first time to take up his duties as Resident. Well known as a soldier to the natives, and having but recently relinquished his office of Commandant, he was met by a deputation of chiefs, who timidly expressed a hope that a régime of militarism would not supersede the sympathetic administration of Mista Ibi. To which the General made answer that "we must hope for the best!" A more guarded reply than that given by one Rehoboam under somewhat similar circumstances.

One little idiosyncrasy I may mention before passing on. Hewby was one of the most upright men on a horse I have ever met, and always rode at a pace which was neither a trot nor a canter, but a sort of amble which made it almost impossible 
to keep abreast of him. It made you wonder whether he was trying to shake you off, or whether there was something wrong with your own pace!

From this time onward I continued to assess district after district, till the whole division had been completed. During my continuous peregrinations I only met two classes of Kanuri-the spoiler and the spoiled. The bigger the man the greater the spoiler, and vice versâ (or "visa versa," as George Seccombe hath it in his Assessment Reports). An Ajia would not think it beneath him to dismount on the road and make the humblest wayside farmer disgorge threepence, or less, if he had it on him. The farmer, for his part, would take this imposition as a matter of course ; nor would he give a thank-you if, having witnessed the affair, one had set oneself to give him redress. He would simply deny that he had parted with anything and deliberately obstruct the course of justice in his own interest! For it is almost useless trying to help the oppressed, because the oppressed themselves only recognize two classes of mortal: the big man who, by the law of "Right is Might," is entitled to pinch anything he can-and is a fool if he doesu't; and the little man, who was ordained by fate to be robbed-and is a fool if he kicks against the pricks and complains to the white man, thereby storing up a worse hell for himself afterwards than if he had kept his mouth shut.

I once quoted an example of "Kanuri-ism" in an official report which amused Tamsie. One of the Shehu's many opportunist brothers, hereinafter 
named Bello, 1 once "fined" a peasant eighteen shillings for saluting the Medical Officer. "I am your master," said Bello. Had the vietim been fined double the amount for not saluting the white man he would have paid up with the same glorious complaisance!

The peasant Kanuri is fair game, not only in the eyes of others, but in his own.

One day two of these unfortunates were walking past the Native Hospital with their loads. Out stepped a trio of Hausa patients. "Ah, here come two Kanuri," said one of them; "we will take their loads." Which they proceeded- to do, nemine contradicente, as they might have unloaded donkeys. "Not guilty!" was their plea in Court; " they were only Kanuri!"

The Sarakuna, of course, knew their peasantry, and filled their pockets accordingly. There was only one honest native in Bornu-the late el Imaum. But, big or little, the Kanuri were all desperate liars-some clever, the majority transparent and futile.

As an example of the former I may quote the late-lamented Sanda Laminomi, District Head of Magumeri, a handsome and attractive old rogue, of very independent disposition, who, if I upbraided him too freely, used to shout: "Dani duwo!" 2 He had been escorting me round his district, and was getting very bored with me and my (to him) quite unnecessary anxiety to locate and map all his tax-units. In due course I asked him to conduct me to Ardoram, a unit on the far edge

1 Vide p. 130. 2 "That'll do! Leave off!" 
of his district. Having arrived and plotted it into my map, I bade him good-bye, and departed to the next district. Several months afterwards I had occasion to revisit this particular unit, and on reaching our objective I exclaimed: "But this is not Ardoram!"

"Yes, it is," replied Sanda's messenger.

"But," I said, "Sanda himself took me to Ardoram, and it was quite a different place!"

" That is so," explained the trembling messenger ; " but, when we reached that town, Sanda was tired, the way was long, and night was upon us, wherefore Sanda said : "We will tell the Judge that this is Ardoram!" "

The average Kanuri lie was so involved, profitless, and generally devoid of beginning or end, that it was waste of time to attempt to disentangle it. Benton, whose gentle bearing was most misleading to the unsuspicious, claims two-and only twotriumphs over Kanuri-ism during his ten years' sojourn among the stupide mendaces, to adapt a phrase. I will relate them in his own words :

A man came in to complain of extortion. According to his yarn an unknown man had come to his village at ten o'clock at night, awakened him and told him there was an European on the road some distance off who was camping in the bush and wanted ten pots full of water. Not unnaturally the villager paid him 10s. to go away and get the water elsewhere. After waiting a fortnight so as to ensure that there should be no possible chance of catching the offender, he came in and laid his complaint. As it happened I was not very busy that morning, and I saw a chance of a little amusement. I asked him as casually as I could, "Did you believe 
this story of there being an European in the vicinity ?" $\mathrm{He}$ considered the question carefully and with true Kanuri cunning spotted the catch. He would not answer the question at first, thought perhaps he had overestimated the importance of his loss, and on reflection hardly liked to trouble me further about the matter. I lit a pipe and said to Nyako," "Go on, rout it out of him!" With a sardonic smile, old camel-face got down to it. After many useless evasions and an interrogatory of about ten minutes, the man sulkily replied, "No, I did not believe there was an European there." "Then why did you pay the man ten shillings?" said I. In a despairing voice and with an imploring look at Nyako and me, he replied, "As a matter of fact, I was lying; I did believe there was an European there." With a fine assumption of virtuous indignation $I$ then demanded in a voice of thunder, "Then what the blazes do you mean by refusing hospitality to a white man ?" Screams of delight from ó móldoe, who had edged round the corner of the office to hear the fun. Of course we never caught the culprit; with a fortnight's start it was not likely we should.

Some thieves visited the station one night, but were disturbed and fled, leaving some clothes behind them, partly their own and partly stolen ones. Later on they were arrested in the town under suspicious circumstances and were brought up to me for preliminary examination. A gown and trousers which were among the clothes left behind were said, on rather doubtful evidence, to belong to one of the thieves. He, however, stoutly denied that they were his. I asked him where he was on the night in question. He said he was sleeping in his house with his wife. I remanded him and sent for the wife. Like a dutiful spouse she swore blind that her husband had never left her side on that night, when by a peculiar coincidence she had suffered from insomnia! I cross-

1 Benton's interpreter. 
questioned her at great length but without avail. With a weary sigh, I said to Nyako, "I fear she's defeated us." The woman grasped the meaning of my remark quick enough, though of course she could not understand the words. A complacent look passed over her face as I told her she could go. Just as she was leaving the office, I called to Nyako, "Tell her she had better take her husband's things out of that pile in this corner there." The woman went straight to the heap and picked out the suspected gown and trousers. A delighted grin spread itself over Nyako's face. She saw her mistake instantly, burst into tears, and called Allah to witness that none of the things belonged to her husband. But it was too late. I thought at the time, and still think, that my little ruse was quite legitimate, but McClintock was tender-hearted, thought it was hardly playing the game, and the thief was not convicted. 


\section{CHAPTER VII \\ BORNU-continued}

AT Ngabarawa, in Magumeri District, I shot a fine Senegal hartebeest; and another at Ngubala, which, being only wounded in the first instance, was chased to a standstill by "Jinks," a bitch which George had handed over to me, and "Piccin." Poor little "Piccin" was lost after this, and eventually found curled up, in her effort to get cool, round a chatty (!) in the rest-house we had left that morning.

From Busugua I passed to Gusumala District, where to my intense satisfaction I shot a Dama gazelle ("farin gindi"). There are only two other places in Nigeria, ${ }^{1}$ I believe, where these are found, namely, Lake Chad, where they are "forbidden fruit," and Borgo. I doubt if any white man had ever been to that corner of Gusumala before, and, for my own part, I never want to go there again, for the burrs, or "kerangia," were unbearable. I looked more like a glorified thistle than anything else after my day's shooting.

Thence to Kanembu District, where I pitched my camp at Kukawa, the old capital and buryingplace of the Shehus and Kauwa in turn. From

1 And outside Nigeria, only rarely in Senegal and Gambia (H. N. Thompson). 
here on October 19th I paid my first visit to Lake Chad. I slept under some trees half way, and was driven by the mosquitoes into my mosquitonet for the night at 5.30, without daring to have any food passed in! Next morning, after passing animals of every sort and kind enjoying the sanctity of the Reserve, and positively obtruding their immunity upon me, I made the Lake at nine o'clock. After a bath in its fetid waters, I sat in a reed canoe, ate fresh fish speared by the Budumas and a tin of logan-berries, gave thanks to the Lord that I had seen Chad, and got away as fast as I could. Chad is the lodestar of every Nigerian traveller; and the Editor of the Sporting Times was kind enough to publish a little outburst I submitted to that paper under the influence of the moment, which ended thus :-

The Greeks from their sepulchres rise and are glad : And are shouting: "Thalassa!" with thee to Lake Chad.

Had those warriors accompanied me one stanza further, and joined me in my slimy bath, they would have retreated disillusioned by double parasangs to their graves, and remained there!

Having completed a lengthy report on the landtenure peculiar to Kanembu, and gradually working my way through Mongonu, Marte, and Konduga, where I had some very exciting rounding up of Shuwa and Beleni stock, I arrived back at Maiduguri a day or two before Christmas. I had only seen one white man during five and a half months' travel, and, my temper having been sorely tried by the evasions of the Shuwa 


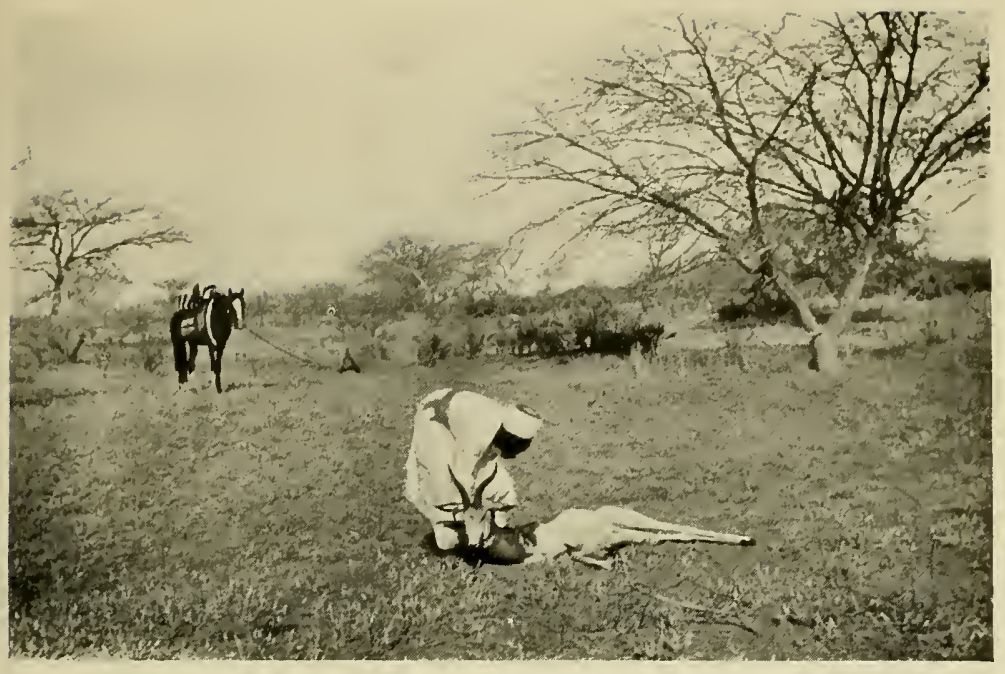

A "FARIN GINDI."

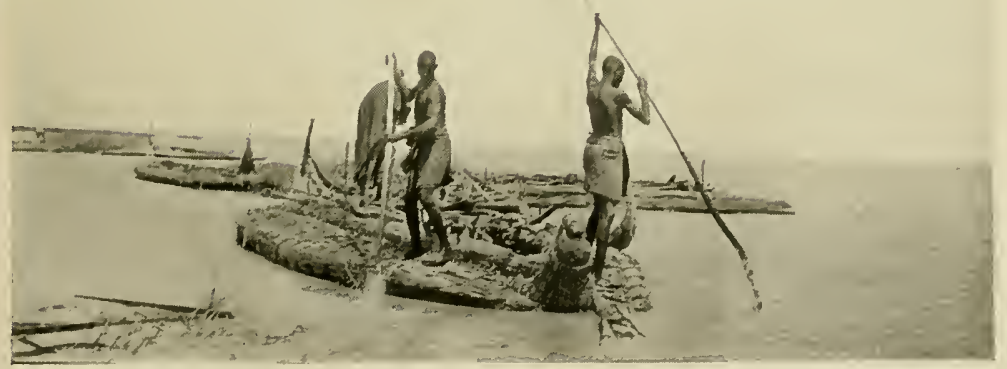

BUUUMA CANOES ON LAKE CHAD. 

Arabs, whose one visible object in life was to make a convenience of British territory in the wet season and of German in the dry, but to settle their liabilities with neither, I was heartily glad to be back again. ${ }^{1}$

Knox had been relieved as O.C. Troops by Aubin, a very musical officer, who enlivened our Christmas dinner in Benton's bungalow with dance and song. Thompson had gone home, and I missed the jaunt with him down to the "Dirimari," or Leper Camp, which was one of his great hobbies, and afforded me a lot of quiet amusement. The wrangling between two lepers as to who was the "headman" of the "row" (both having about two months to live); indignant women shaking their stumps of fists at Thompson because he had handed over their children to foster-mothers ${ }^{2}$; the escapes and returns, etc., were all a fruitful source of interest.

After a rest of about a fortnight I sallied forth again to assess my last district, Marghi ${ }^{3}$ and Chibok. ${ }^{4}$ Marghi was an independent State, administered at this time temporarily by one of the Shehu's "kachellas," one of the stupidest and most dishonest men it has ever been my lot

1 I have since been assured by Bornu scholars that these Arabs are $(a)$ "the only class that really ought to count in Bornu," (b) "quite good fellows." I may have misjudged them.

2 It is a curious fact that these lepers used to intermarry; and their children, weaned after a fortnight, grew up entirely free from the disease.

3 Vide Notes on Nigerian Tribes and Emirates p. 271 (O. Temple).

4 Vide ibid., p. 86. 


\section{THE SNUFF-FOLK OF CHIBOK}

to deal with. The Marghis, on the other hand, were a pleasant relief after the Kanuris. Truculent and quick-tempered, they were at the same time hard workers, intelligent, and absolutely straightforward. It was a ticklish proposition applying the Thomson assessment scheme to these raw pagans, and a matter of speculation how they would receive it. As a matter of fact there was not the slightest trouble as far as the Marghis were concerned, and it was not till I tackled the Chibok sub-district that I met with opposition.

The Chiboks were a most unsatisfactory crowd to handle. Of an evening they would come to me in a state more or less of intoxication, cheerfully tell me they quite grasped what I wanted, and say they would pay anything I liked to demand. In the morning, however, when I returned their call, either they would vanish, or the few who were left would be so befogged with snuff that I could get no sense out of them. After some days of this parleying without getting any forwarder, I had to intimate to them pretty clearly that I should be constrained to reintroduce them to the troops (who under Wolseley had already dislodged them from their fastnesses on Chibok Hill ${ }^{1}$ ) if they did not give my staff facilities for making the census, and collecting the data I required.

In the meantime I undertook a very arduous trek along the Yola-Bornu boundary eastward to the Cameroon border, having received instructions to elucidate a territorial dispute in co-operation

1 The siege of Chibok is an old and well-known story. 
with Acland from the Yola sidc. He, however, was taken ill, and I had to make my investigations single-handed.

I returned to Chibok in time to witness the obsequies of an old man, whose age I was informed on good authority was 126. The people quoted the various historical landmarks by which they had arrived at this calculation.

One of them tickled me immensely. Seven years ago, they told me, when he was "only 119" (sic), the "Judgie Dumboa" 1 had had him deported from his own village to Chibok, as being a turbulent character and a danger to the community!

A solemn lying-in-state was held: the venerable patriarch was decked in a pair of dirty red trousers, and his young widow, aged eighty, set to fan his mortal remains, while the crowd drank " pito," and danced round them. At dusk a grave was prepared, and the senior "elder" chanted a drunken dirge, as the deceased was lowered into his last resting-place. At intervals the dirge would die away to a sort of murmured incantation, while the elder performed what I took to be analogous to our own rite of "earth to earth" -for, after our own fashion, he dropped something into the grave three times. As a matter of fact I learnt afterwards that it was not earth but thorns, and the interpretation of his mumblings was somewhat as follows: "God put a fence between you and us: your days are finished, and with them vanish many secrets of the past:

1 George Seccombe. 
rest behind the fence in peace, and do not return to disturb us!" Laying the ghost, in fact.

My hint about troops had been effectual in the case of Chibok village itself, and one or two others; but the remaining units gradually got quite out of hand, and I therefore reluctantly sent in for an escort to help me enforce orders. I received word back that Lieut. Crosbie and thirty-five rank and file were being shortly dispatched from Maiduguri. To my surprise and gratification, a few days afterwards, who should turn up but Dudley Crosbie, an old schoolmate of mine both at Winchester and at Jack le Fleming's cramming establishment at Tonbridge!

After much bucking about old days, we proceeded to round up the recalcitrant villages with the usual unsatisfactory results. The inhabitants would neither parley, nor come to terms, nor fight. They simply effaced themselves, and left us to collar sufficient grain to cover the tax due in each case, plus a salutary fine. We realized this grain at the current price of 1s. per 8 saas. $^{1}$ At only one village did we meet with stout resistance, and this was in the shape of an old lady, who used the most shocking language, and resolutely declined to be dislodged from her settee of cornstalks, to which she glued herself tenaciously till she was pulled off, when it was found that she had been sitting upon some twenty quivers and one hundred odd poisoned arrows. These were destroyed, to her intense indignation.

11 saa $=25 \mathrm{lbs}$. (circ.) a very different price to that of the famine year of 1913-14, when at Geidam 1 saa fetehed Ss. ! 


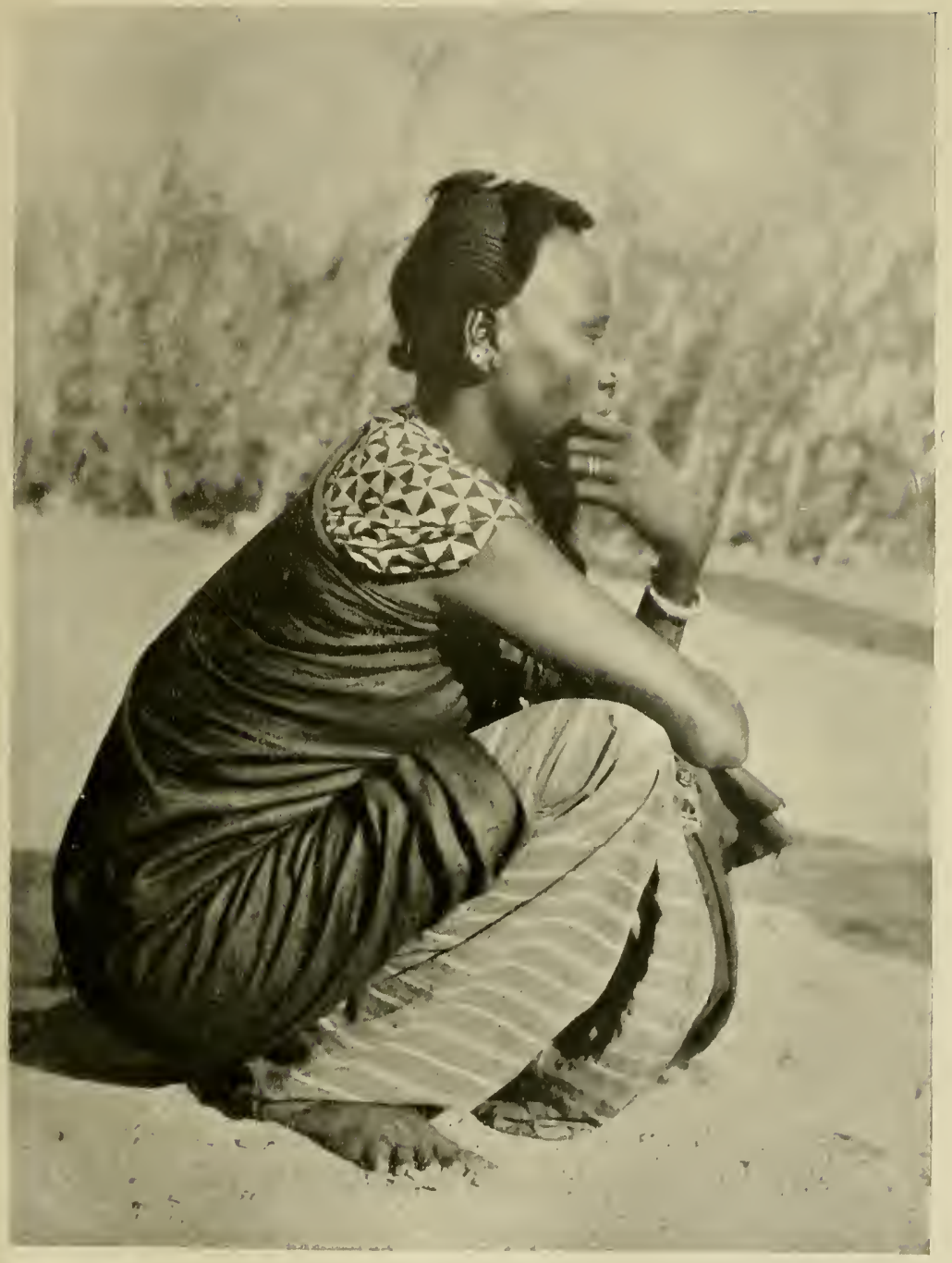

A KANURI WOMAX. 

There had been some unrest along the East MarghiGerman boundary; and Crosbie had been asked by Mr. Hewby to return by that route, and show himself with the troops. On arrival at Mulgwe news was brought to me of a robbery of donkeys by some ruffians at Mudube, a town right up against the German border.

An extract from my diary on the action taken by us may not be without interest.

I was met by the Native Court, who informed me that the mburma of Mudube was "wanted" for the theft of four donkeys, and that repeated summonses during the last two months to appear at their court had been disregarded by him : and any attempt to arrest was frustrated by his slipping across the boundary, which he had done periodically with the donkeys.

2. I therefore asked Lieut. Crosbie to push on with me to Mudube in the rather forlorn hope of surrounding and surprising the town, and then arresting the delinquent. The chance of our succeeding in this depended on the fact that when I visited Mulgwe ten days previously, I had sent Musa to Mudube to get information as to the farming, population, migrations, etc., and I therefore hoped that by sending Musa on slightly in advance again on this occasion, to engage the mburma in conversation, we might disarm his suspicion, and close in upon him before he was aware of our presence.

3. We started for Mudube accordingly at 1.30, taking the Native Court with us. On arriving within twenty minutes of the town, Musa went on ahead, and Lieut. Crosbie sent ten men (accompanied by Malam Kachella for purposes of identification) to flank the north and west of the town, while he proceeded himself with the remainder of the troops to line the river on the east and south in order to intercept the mburma, should he try to escape to German soil. The labourers, camp-followers, 


\section{THE LESSON OF ISGE}

etc., were ordered to remain behind with Courier Idrisa.

4. Meanwhile Musa called the mburma, and told him that I should be visiting his town, and should require a rumpah under the big tree adjacent to his compound. They went towards the tree, when Musa said in Hausa to Malam Kachella, who had now come up, "This is the man." Malam Kachella started to speak to him, and at that moment the mburma caught sight of the soldiers, and made to run away. Malam Kachella immediately closed with him, but the man broke loose, leaving his cloth behind, jumped a fence, ran into a house, and seized a spear. He then made for the river, stopping to hurl the spear at Malam Kachella-whereupon Musa threw his spear at him. The man picked it up, and hurled it at Musa, luckily missing him. By this time they were within fifty yards of the boundary, and the troops now opened fire, and killed him.

5. Meanwhíle, two of the mburma's party were letting fly arrows at Mr. Crosbie's men in the river-bed, who succeeded in killing one, the other escaping wounded into German territory. Nothing further occurred, except for a half-hearted advance of about twenty fugitives armed with spears in the direction of the carriers-but these were easily turned by Idrisa firing a shot from his carbine. We then pitched camp, and food was brought by the very few inhabitants who had not run away. Three donkeys were found in the mburma's quarters, and these were duly handed over by the Native Court to the victim of the robbery: so that our object was doubly achieved, and a lesson taught to these people, of which the robbers of Isge may well take note, namely, that though they live right on the edge of the river, this boundary is not an infallible means of escape from the consequences of their depredations.

6. It was a prompt performance on the part of Crosbie, and the whole arrangement exactly timed so as to effect a thorough surprise-no easy matter in a country where 
news travels so rapidly, and especially where sanctuary is a matter of two hundred yards away.

As an illustration of the cheery habits of the good people of Mudube, I may mention, en passant, that in one of the huts near which we slept that night we found a man (who had presumably annoyed some neighbour) lying with an iron spike through his brain. On his body, peacefully sleeping, was curled up a pie dog!

From Mudube we made tracks for Mainta Maleri-a long trek of thirty odd miles through waterless bush. We decided to go our ways, each taking one side of the road, have a shoot, and join up again later at a certain pool, about which our guide told us. The guide decamped, and we failed to find either the pool or each other that night!

After shooting a roan about ten o'clock, I worked my way back to the road, and eventually struck the main body of our convoy. Having fired off my rifle several times to let Crosbie know where we were, I then moved slowly forward. At 6 p.m., being beat to the world, and not having seen water since the early morning, I decided to camp for the night. A sparklet syphon half full was all I had left in the way of liquor. This I gulped down, and turned in. The labourers, etc., were nearly mad with thirst, and we had not the faintest idea where we were, or how far from the nearest water.

At 2 a.m. some nomad Fulani strayed through our camp, and one of them volunteered to guide 
us to Mainta Maleri, where, to my great relief, we arrived at nine o'clock next morning, and found Crosbie tattered, begrimed, and in the last stages of exhaustion. He had somehow wandered into German territory, struck a small hamlet, and, regardless of consequences, drunk a huge draught of filthy stagnant water-fortunately with no evil effects. From there he had been conducted to Mainta Maleri, and reached it about the same time as myself. He had shot a fine reed-buck during his wanderings. Thence we passed through Konduga District, and back once more to Maiduguri.

I omitted to mention that from Marghi I had written to Mr. Hewby, "having the honour to remind him that my tour expired on the 3rd prox. (March)"; to which I received the characteristic reply: "Yes, but you write as if you had to catch a particular train-which as far as I know is not the case." I now received another little rebuff, the quiet humour of which amply compensated for the shock to my vanity. In my report on Marghi I had shouted "Heureka!" and announced that I had traced the connection between the Huyam River and a small mysterious stream running into Alo Lake-" a feature," I wrote, "hitherto undiscovered." To which the Caustic One, in a marginal comment: "Except by me in 1904.-W. P. H."

George had now arrived, and was to relieve me. George was a great little person. I found him enveloped in maps, plans, and harness. A large brandy and soda was by his side, his hair was 
slightly on end, and he was engaged on the compilation of a one over a million map of the province. "Look here, Harry, I ask you!" he cried as I walked in, "on the top of this map, which is the devil's own sweat, Hewby has told me to have two plans of the station ready for to-morrow's mail. It simply can't be done, and (helping himself to another wee brandy) I'm damned if I do it!" "Quite right, George," I replied, "you keep your end up!"

Next morning at about six o'clock, peering out from my house in the fort, I descried George puffing and blowing, and laden with survey paraphernalia. "Sanu, George!" I called; "up betimes! What's afoot?"

"No, don't humbug me, for goodness' sake, Harry!" he replied, "I've got to get these two damned plans off for Hewby by to-day's mail!"

Hewby, like Parnell, could always get the last ounce out of his men, because, like Parnell, he never asked them to do what he would not have done himself. George, like Tom Davitt, Kickham, and Pat Egan, had forgotten his overnight threats. ${ }^{1}$

Polo had been started at Maiduguri for the first time, and the Lake Chad Polo Club formed. George, who had got it going, had the best horses and was far the best player. There not being enough Europeans, some of the most promising native N.C.O.'s were mounted and taught the game-as far as we, ourselves only learners, could teach them; and, from that time forward, polo

1 I promised George (but not on oath!) not to publish this. 
flourished. Even if there were only one or two white men available, $\mathrm{Pa}$ Benton made a practice, and a very good one too, of keeping the game going regularly two or three times a week. The natives, though they called it "aiki," got as keen on it as we were. Later on we had great matches -Black $v$. White, which aroused keen enthusiasm. The former had the best eye, and hit the hardest, but lacked the brain-play and combination; so that the sides were pretty even.

By the end of March I had completed a tour of fifteen very strenuous months, incessantly trekking, and having slept at over three hundred different towns all told; and I felt too thoroughly weary to face the long twenty-four days' journey back to Kano on a horse. So I bought George's spare light trap and horse for $£ 25$, and trusted to being able to re-sell it at Kano.

The road between Geidam and Maiduguri was appallingly sandy, and the going so severe a strain on the horse, that one could only go at walking pace most of the way. After Geidam, however, it got a bit better, and also, as a relief horse, I bought the famous "Danda," 1 whom I put straight between the shafts, and drove without any breaking!

The trek to Kano viâ Katagum was uneventful, save for an encounter with a wounded wart-hog, whose onslaught Bisalla bravely received with a

I A piebald, who subsequently must have covered almost all the possible mileage in the Protectorate. I used to drive him to the polo-ground, ride him in two chukkers, and then drive him back! 


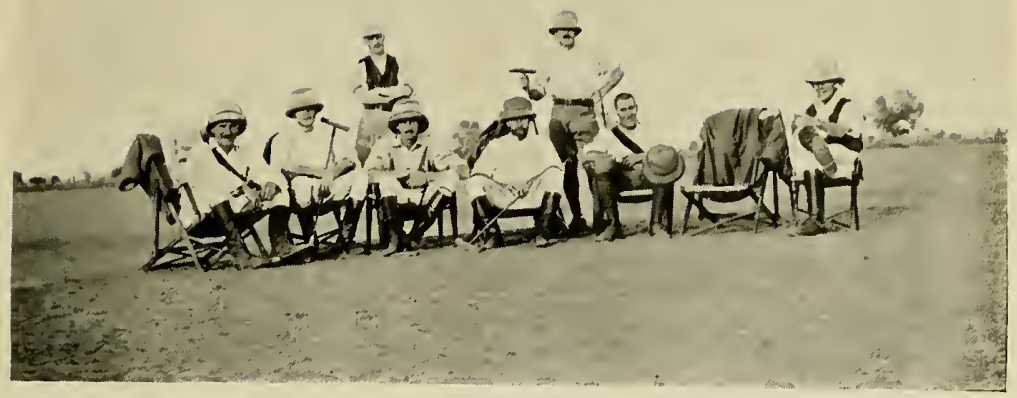

A LAKE CHAD POLO-CLUB GROUP.

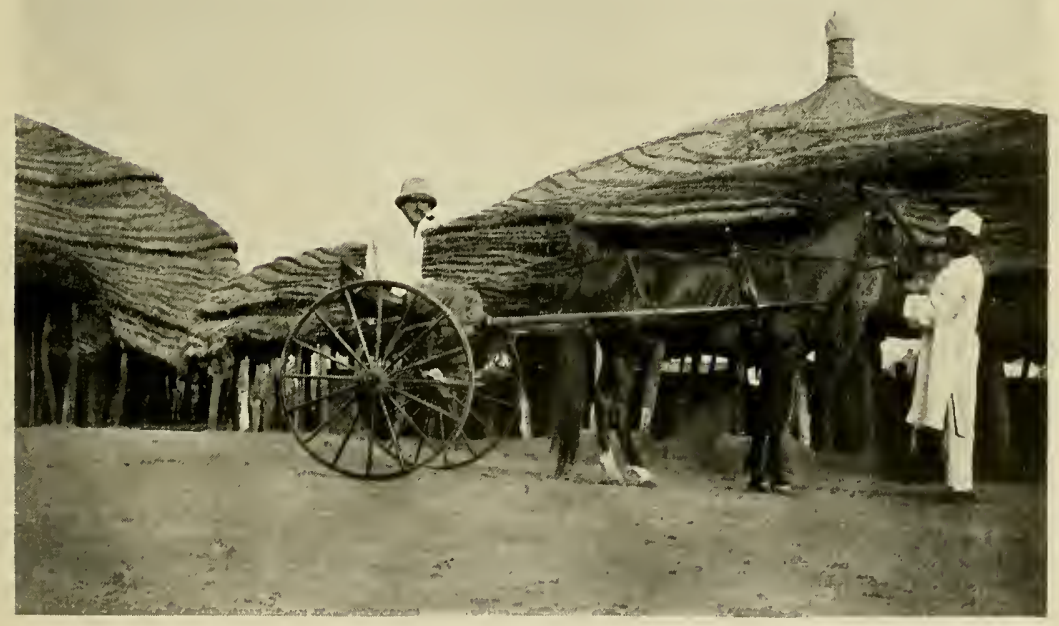

MY (LATER DE P.'S) TRAP. 
spear. He cantered the whole of those twentyfour days behind my trap on his sturdy little horse with a dropped hip!

At Debbe I fell in with a French Medical Officer from the Territoire Militaire, and we had an amusing little dinner, at which we were joined by Cook, of the M.I. The latter had had a strenuous shoot in the afternoon sun, and developed a proportionate thirst. Towards the end of the meal he turned to the Frenchman, and somewhat startled us by asking:

"When are you going to have a king?"

"Ah, mais qu'est-ce que vous dîtes là, M'sieur?" politely replied our guest.

"My dear old bird," persisted Cook, "it's no good, you've got to have a king!"

"Mais ça, par exemple, ca ne s'arrangera pas sans qu- "

"Look here, it's got to come, I tell you! And the sooner the better!" And in this he persisted till he became somnolent, and finally slept.

"Monsieur est très fatigué," I lamely tried to explain to my French friend, "il ne veut pas dire sérieusement que_"

"Ah, mais pas de qoui, c'est entendu, Monsieur! Sans doute le soleil___"

"Parfaitement!" I replied, grasping the straw. Monsieur and I had many a laugh about this afterwards when we came to know each other better, as we did when we renewed our acquaintance later on in the ship.

At Zaria I met the accommodating Sainsbury, sold him my trap, and thanked him in a few 
well-chosen words for his kindness in taking my roan-head as far as Kano. ${ }^{1} \mathrm{He}$ received it very kindly, and did not allow it to worry him at all. Early in May I reached Lagos, and embarked, together with "Piccin" and Bisalla, whom I had settled to take to England, on the Akabo (Captain Davis). We reached England at the end of May, and Bisalla got his first introduction to the eccentricities of the white man's life in that country during our stay for two or three days at Plymouth as guests of my brother Claude on his ship, H.M.S. Powerful, which happened to be at this port. Any homesickness he might have been suffering from at first was quickly dispelled by the cheery naval atmosphere, and a present from my brother of a suit of navy blue made by the ship's tailor.

1 Vide p. 100. 


\section{CHAPTER VIII}

\section{BORNU-continued}

BisalLa, during his five months' stay in England, had seen and done many things. He had fallen out of a motor unscathed; he had been cautioned by the village constable for riding a bicycle without his hands between two passing motor-vans to the public danger, and accused by the same official of arson-in that he had set fire to a certain gate with a certain explosive, to wit, a squib. The former charge he had parried airily with the defence that the alleged danger was entirely his own, the latter with a request to be handed the Koran. The logic of the first, and the significance of the second, having entirely baffled the earnest constable, the charges were not proceeded with.

He had watched aeroplanes with the utmost unconcern, and caddied on all the local links, as if it had been his vocation from birth. ${ }^{1} \mathrm{He}$ had seen a circus, the only indication as to his attitude to which was his remark that he supposed the clown who slowly took off fourteen pairs of socks in succession, was an Emir, and an aggrieved comment

${ }^{1} \mathrm{He}$ distinguished himself his first time out on the links. I had called to my opponent inquiring his score, and received the reply "Three!" Whereat voice from Bisalla: "Haba! Fudu!" 
to the effect that the emergency net, spread beneath the acrobats in their trapeze act, was a "fool thing," since it prevented them from hurting themselves, and so rendered the performance pointless. The horse that harnessed itself, the elephants who "passed chop," and the sea-lions who juggled with lighted candles he accepted as mere white men's freaks.

$\mathrm{He}$ had also been to church, and observed afterwards that he had paid threepence both at the church and at the circus, but whereas one was good value, the other was "kurdin banza." 1

For my own part I kept up my Hausa, and found it not unpleasant to be able to shout: "Boy, do this or that," in the same jolly old way, instead of ringing the bell and asking Emily "if she would mind just bringing my boots," etc. As I have said in a previous chapter, no "girman kai" 2 ensued, and, in fact, he has scarcely ever alluded to his English trip since, except when the subject has been raised by me.

Which things having been accomplished, as Cæsar says, we embarked on board the Appam, ${ }^{3}$ (Captain Harrison) and sailed again on October 15th. This was the first time I had travelled on one of the new boats, and calling at La Pellice and Teneriffe was also a fresh experience. It was on this voyage, in case there is anyone in Gath who knoweth it not, that a gentleman who shall be nameless boldly inscribed himself upon

1 Waste of money.

2 Swollen head.

3 This boat was afterwards captured by the German raider Moerve. 
the bath list for "Wednesdays and Fridays only," whereupon others instantly took courage, and their pens, and wrote down likewise.

B-bank was on board, and hastening out to Kano for a stay of one week, to return in record time by a series of boats, viâ, I think, Dakar and Barcelona! I arranged to buy a light ponytrap from him on arrival at Kano-mainly to save "Piccin" that weary trek of twenty-four days in a box. Alas! she was not destined to reach Kano. Being very seedy, I was sleeping on a settee in the boat-train with "Piccin" curled up by my side. I was suddenly awakened by Bisalla, who had gallantly fought his way along the whole length of the train and was asking me whether "Piccin" was with me, as an Arab had seen a white man's dog on the line. A sickening feeling came over me as I realized, after a futile search, that she must have fallen from the train-how, I never discovered.

I was too ill to do much myself, but on arrival at Zungeru, Sheriff, the Traffic Superintendent, promised to send a trolley back down the line, and I left Bisalla behind to go with it. I also offered rewards, and wired to everybody who could possibly assist me, without avail. All I ever learnt was that a clerk had seen her running along the line, and, greedy for the reward, had given violent chase, instead of gently calling her. Being a terribly sensitive bitch, she had diverged into the bush, and that was the last that was ever heard of her.

No one who has never become entirely dependent 


\section{THE TRAGEDY OF "PICCIN"}

on a dog for company for months at a stretch in the lonely, depressing outposts of Beyond can possibly realize what a shock this loss was to me. Only half an hour or so before the tragedy, Mrs. Guggisburg, who had seen me sitting on the edge of my seat to make room for "Piccin" to get comfortable, had chaffed me with the remark, "I believe you'd do more for that dog than you would for a woman."

For three tours and as many leaves she had been my devoted little companion, and the thought of her probable fate made me quite sick. Even now I hate to dwell on it. How I missed the sweet cold nose pushed through the mosquitonet begging me to get up of a morning, and the secret plots and plans for the day's hunting whispered into the ears of "Jinks." For many a day afterwards I would instinctively put aside the " cutleg" bones, and then, with a chill, remember. It was indeed with a heavy heart that I set out in my trap for Bornu.

At Katagum I found Francis and Wightwick. The former, having just arrived and taken over, had been suddenly ordered to hand over again to Wightwick, and return to Zaria. These changes of mind on the part of the powers that be, were quite the order of the day. The little matter of cost of extra transport over a few hundreds of miles, wear and tear of kit, and losses in swamp and river, were a subject of supreme unconcern to the "O.C. Dispositions" at Aiki Square."

${ }^{1}$ So called because all the real work is done there (vide Chapter V). 


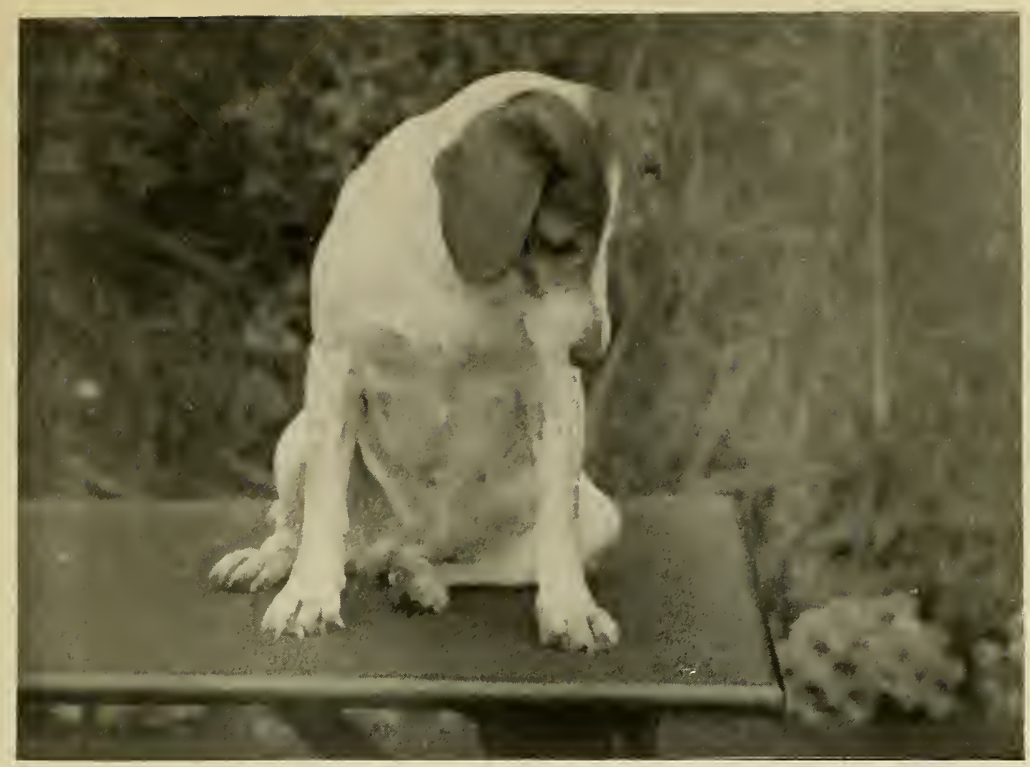

"PICCIN"

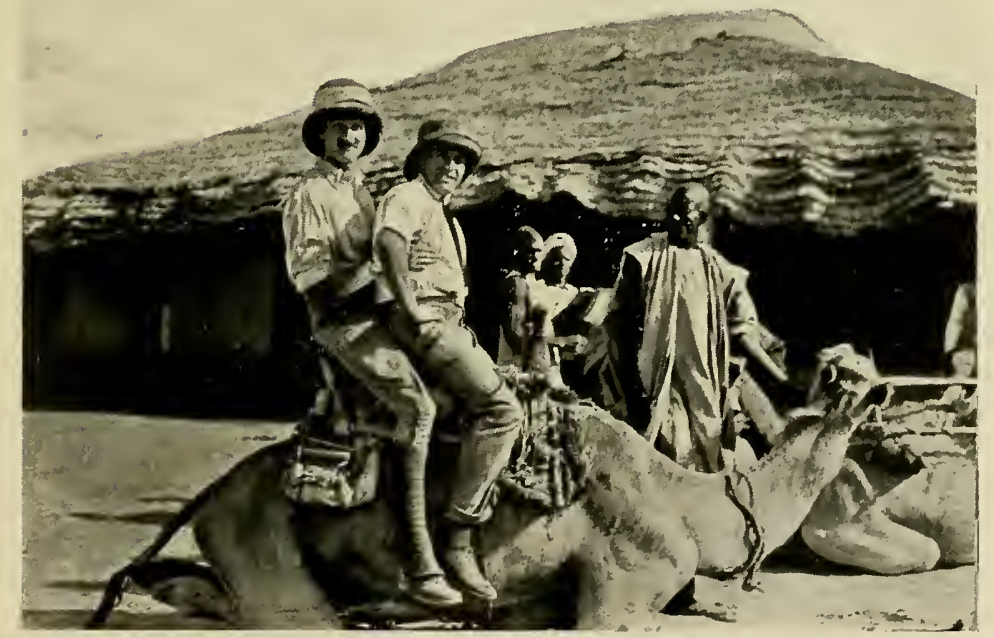

THE START FRON GEIDAM FOR GUJPA. 

As for the waste of time, as I have said before, the supply of Government time is-like Luxunshrinkable.

The following tour, for instance, the officer whom I had relieved at Numan had been there exactly ten days when he was recalled to Bauchi, and had to return over the two hundred and forty or so miles which he had traversed from Bauchi-in other words, a waste of thirty-two days all told on the road. During the same year an officer who had served the previous tour in Sokoto 1 and left a quantity of kit there, on arrival back in the country found himself posted to Benin City, ${ }^{1}$ whither it was proposed that he should transfer the said kit at his own- - but my lips are sealed on matters controversial!

We all dined with Francis that night, and of that party three of us were destined to sail on the Falaba on her last voyage-Francis, myself, and Silcock, who was drowned. At dinner I thought I behaved like a perfect gentleman, but Francis has since told a story about a bull terrier and Bombay duck, from which it appears that I said -but it is his story, not mine, so I will not retail it. I do not care for Bombay duck, and there's an end of it.

Near Juwor I came across a very fine warthog, and leaving the trap in charge of a labourer, I went off after it and secured it. On my return I found that the labourer had let go of the reins, and "Danda" had careered off the whole way to Jawa, the next camp. The wonderful part 
about it was, that despite the badness and narrowness of the track, the trap was undamaged.

At Geidam I found George Seccombe, from whom I took over again, Hastings, Sainsbury, and Davis the doctor. There was real good polo, under the ægis of the M.I., Lane ${ }^{1}$ and Longbourne ${ }^{1}$ being experts, and Drummond ${ }^{2}$ almost international form. They were not there long, however, being relieved by Lambert ${ }^{1}$ and Austin, and the new company. The troops, after their prolonged spell at Geidam, had nearly all had eye trouble of some sort, caused by the dust and sand which is so trying a feature of Bornu.

There was excellent shooting round the station, and one night I shot a couple of bush-pig and placed them as bait for hyena. Lambert, Davis, and I arranged to have dinner at the edge of the "fadama," and then quietly take up our positions and wait for the quarry. We had a most cheery dinner, and then took our places near the carcasses as arranged. After about half an hour's waiting I could stick it no longer, and suggested in a whisper to my somnolent companions that we should give it up. This was carried unanimously. Examining the bait, we found that while we had been having our chop, the hyenas had had theirs, and made a very sorry spectacle of the pigs.

George, Davis, and I had great fun of an evening with the guinea-fowl and duck, though the latter were very expensive in cartridges.

Christmas night was a very riotous affair. The

1 Killed in France.

2 Killed in Gallipoli. 
accomplished Sainsbury challenged us all to shoot threepenny-bits in the moonlight with revolvers, did step dances, and finally rode his horse " Digma" (previously warned off the polo ground for misbehaviour) up the steps and through Hastings's bungalow. The last rite I remember performing that evening was pouring beer down one end of a hunting horn while George endeavoured to blow calls up the other.

Next morning George departed for Maiduguri with his trap, his dogs, his horses, and everything else that was his for the more edifying occupation of sweating up Hausa, while Hastings departed to Kano for his Higher Standard, and home.

A few days after I left for Gujba, along one of the worst and most waterless roads I have ever traversed. Very welcome was the hospitality provided for me by Hopkinson, generally known as "Hoppy," on my arrival. He left next day to assess the parts about Biu.

An extract from his subsequent assessment report I cannot refrain from quoting for the guidance of those to come. "After my messengers had duly assessed and collected the tax ... they were murdered"! The italics are mine; the exclamation was Tamsie's when he read the paragraph.

I had some most enjoyable shooting in the fadama near Gujba, including guinea-fowl, marabout, reed-buck, and "derri" (Senegal hartebeest). Of an evening I was entertained by the local "magic" man, who circumscribed himself with cobras, swallowed needles, and laid eggs. 
From Gujba I diverged to Dumboa, and after a short sojourn there arrived in Maiduguri. Hewby had left for good, and Tamsie reigned in his stead. I have already done the latter less than justice in the appreciation to which I referred in Chapter VI; but, as I do not wish to be fulsome, I leave it at that, save to add that he was the whitest man, the soundest officer, and my greatest friend in the country.

The country was in the grip of famine.

It had rained twice during the year 1913: grain at Geidam had risen to as much as 8s. per saa : the population, normally dependent on the millet crop for their daily bread, were starving and dying like flies. Wholesale migration was the order of the day, and famished peasants were breaking up the very ant-heaps in a frenzied endeavour to avail themselves of the granaries of the ants.

Tamsie was at his wits' end how to cope with the state of affairs, when salvation suddenly presented itself. He afterwards gave me credit for the idea, but $I$ always thought the brain-wave occurred to us both over one of his gin and kola cocktails.

It was an open secret that the sarakuna and "big men" of Bornu made a practice of hoarding immense quantities of corn in their compounds, not, like Joseph, from any forethought for the future, but simply as a token of wealth, much as the rich man nearer home likes to boast a fine cellar or expensive pictures.

It was now suggested to the Shehu that these 
noblemen should disgorge their stores, and week by week take turns to put upon the markets a supply sufficient to meet the essential requirements of the station and the neighbourhood. Then when the 1914 crop was harvested, and the grain market normal again, a proportion of the tax due from the fertile districts round Gujba and Marghi should be levied in the shape of "zakka" 1 instead of cash, and these magnates given their choice of taking a settlement in money if grain was cheap, or in kind if it was dear. They were on a winner, so to speak, in either case, since at the worst they would be getting new grain for old.

As soon as they grasped how they stood they welcomed the scheme with fervour. There was only one thing against it-another failure, but this was very unlikely. Moreover, the malamai happily prophesied a year of plenty. The scheme was acted upon, a careful account kept, and the situation more or less saved. I say more or less, because even so the price was severe, and the demand still far exceeded the supply. Every Wednesday the Shehu stocked a specially erected barricade with grain for the paupers of Shehuri and Maiduguri, and horrible scenes ensued when the women swarmed round and fought and clawed each other for every handful doled out. Till late at night children could be seen scouring the sand for such particles of grain as might have fallen by the wayside.

It may give some idea of the difficulties with

1 Originally a "tithe" of grain for religious or charitable purposes. 
which we were faced if $I$ reproduce here some notes on a report $I$ had to submit upon the peculations of a chief whom (in the hopes that he has now mended his ways) we will call Bello.

2. The total amount of grain which appears definitely levied but almost entirely unpaid for, is 12,394, which put at the minimum value of 6 d. per saa (N.B.-Corn is now at 1s.) represents a cash total of $£ 309$ 17s. Over and beyond this $£ 98$ 3s. 9d. in cash was collected from the talakawa under various pretexts. This I consider to be a moderate and minimum statement of Bello's liabilities, a host of other complaints outside the list under examination having been brought to my notice, but not sufficiently supported by evidence to warrant active inquiry.

3. As far as the grain is concerned, Bello himself is undoubtedly the principal: but was probably backed throughout by his elder brother, whose generous assistance in putting his granaries at the former's disposal was not entirely disinterested. Taking advantage between them of the order to supply 3,000 saas to the leper camp, they arranged for the grain to be stored at the Shehu's palace; and whereas 3,000 saas were certainly delivered and $£ 100$ paid to Bello in settlement by the Beit-el-Mal, nobody knows what became of the money, or the exact amount of grain actually stored, except the storekeeper, Bello and his brother. Whatever the latter's exact share of the spoils may have been, it was palpably obvious that extortion was going on, and if he did not know it he ought to have done.

4. As for the part played by Bello's boys themselves, in some cases they appear to have been hoodwinked by Bello as to the contributions allotted to the respective towns. E.g. in the case of Go, whereas he informed the Resident the amount was $\mathbf{3 0 0}$ saas, he instructed his boy Maikurgum to collect 700. In other cases the amount tallied with the list submitted to the Resident, and the 
boys forced up the levy on their own. The unfortunates who could not produce sufficient grain to satisfy Bello's greed, were made to supply animal transport, while those who could produce neither had to make good in dollars.

5. The cash extorted went partly to Bello direct, but for the most part were connived at by him as reasonable remuneration to the boys for their trouble in collecting the corn. The countless cases given in all their detail would fill pages, but a few of the methods by which cash was raised may be quoted, as illustrating the credulity of the helpless Kanuri. Bello, but in most cases his boy, would appear and say :-

(a) The grain was found on unloading to be short, and a small contribution would square the deficiency.

(b) Owing to the market corn having arrived late, the Resident was angry, and there would be trouble for the talakawa unless they paid so much for Bello to intercede.

(c) Abba Bello was coming to camp, but could be persuaded for $£ 1$ to camp elsewhere.

(d) As they possessed no bullocks to carry the corn, the cash equivalent would meet the case.

(e) On payment of so much the saas should be measured in "economic sized drums"!

Etc., etc.

There were other cases, quite unconnected with the delivery of grain, in which these boys arrogated to themselves the rôle of itinerant judges, and fined one man 15s. for assault, another $£ 2$ for bush-burning, and another 18s. for saluting the Medical Officer in the presence of Bello.

6. The Kanuri is ready to buy peace with his Ajia at any price, and as explained in Resident Bornu's Quarterly Report, owing to the conduct of the Shehu it was neces- 
sary, with the district already disorganized and harassed by Bello's rogues, to assure the talakawa in the course of collecting information that they should not be dragged in to give evidence, and therefore it has not been lound possible to secure the conviction of all the fifteen odd boys concerned. Fortunately, however, a clear case was proved by voluntary witnesses against the principal offender and chief Wakil, Kachella Kaura, whose crime was but one of a series, obvious but not proven, and an exemplary sentence of two years' imprisonment was passed. Guilt on a minor scale having also been brought home to one Maikurgum, whose defence was that the $4 \mathrm{~s}$. pocketed from the V. Head of Go was a "fatherly dash" or earnest of goodwill. Unfortunately, at least six other parental contributions of a similar nature are pretty well known to have been paid over in other towns to this importunate "son."

7. For the reasons given it is necessary to deal with the affair administratively, and it is not easy to recommend what is the most satisfactory course to pursue. It is a disgusting reflection that the one district of all others which could have been depended on to meet the demands of most of the population of Bornu, should have been exploited by Bello for his own ends, and the peasantry hunted and bled till they were driven to concealing the existence of grain, instead of pushing its distribution. The result is impossible prices and hunger. It is an easy matter, however, to depose Ajias, but not so to replace them : and Bello's record in Yajua has not hitherto been an entirely bad one. Such an opportunity for filling his pockets would have been unfailingly seized by any other Ajia in his shoes. At the same time his immediate return to the district would be highly impolitic, since it would be regarded by the Shehu as a triumphant vindication of his repeated assertions that the district cannot get on without Bello, and by the talakawa as a fresh proof of the futility of the weak complaining against the strong. If there is no grave objec- 
tion, I would suggest that a respectable representative of the Shehu (if one can be found) be put in as temporary Wakil for four months, assessment postponed for a similar period, and Bello confined to Maiduguri, where more direct contact with Headquarters and proximity to the Political staff may teach him a sense of the difference between meum and tuum. He might then return chastened to the collection of his taxes.

8. The return of the boys to renew their misdemeanours, with the added zest of having "bluffed the judge," is out of the question, and they should be entirely replaced on Bello's return if he is allowed to do so. If it is impressed upon them that at any moment evidence may crop up, which shall entail their arrest, and trial by Government or Native Court, they may find it wise to remove themselves to other spheres, and so rid Shehuri of a crowd of vagabonds.

9. As to the grain and cash extorted, the statement given of which, as pointed out in paragraph 2 , is a very lenient estimate, $I$ would suggest that Bello refund the largest proportion that his salary will allow in cash, and the remainder in grain, up to two-thirds of the total amount; and that his brother, who has been so anxious to help him throughout, should assist him further by refunding the remaining one-third.

It was in connection with this famine that I had the luck of a lifetime. I have said that wholesale migration was going on. The bulk of the agricultural classes were drifting towards the fertile districts to the north in the precincts of Chad. This terrain afforded great possibilities for irrigated crops, and cotton, tobacco, indigo, etc., already flourished in spasmodic patches north and east of Mongonu. It may be wondered, therefore, why it was only the prospect of starvation that had driven the farming 


\section{ELEPHANTS' GENTLE PRANKS}

population to fall back upon such attractive country.

For one thing the mosquito made life unbearable there. But there was another scourge, which not only frightened the farmer personally, but made farming a rank speculation instead of an investment, namely, elephants. Rejoicing in the immunity they enjoyed, ${ }^{1}$ these mammals crashed about at pleasure, trampled any farms they happened to encounter into obliteration, and generally put an effective check on any agricultural enterprise within a radius of, say, eight miles from Chad.

This had frequently been the subject of comment by officers touring Kanembu, but, be it confessed, I used to regard this rather as the protest of the thwarted shikari than a disinterested appeal on behalf of the native. A personal visit to this area, however, very soon proved to me that, if anything, the damage done by these elephants had been understated. The piling of the Pelion of famine on the Ossa of elephantine piracy now made it more than ever imperative that some action should be taken to protect the native, and strong representations were made to Headquarters. Only a few days previously a rogue elephant, not content with wiping out a cotton farm, had caught the cultivator and crushed him to pulp with its knees.

To my joy Sir Frederick Lugard gave sanction for the killing of one elephant. Tamsie was on tour, and I persuaded $\mathrm{Pa}$ Benton to keep the

1 Vide Chapter VII. 
precious news for the former's ears only-for I feared that some of the W.A.F.F. sportsmen might claim a lien on the expedition. $\mathrm{Pa}$, in forwarding the letter, added that "Mr. Langa Langa was available for this purpose." Tamsie, who did not care twopence about shooting, replied that, " if I could make it convenient," I might go-and I did, post haste!

At the camp before Mongonu my dear boys succeeded in getting the flannel round the pullthrough wedged firmly in the barrel of my rifle; and, without a word to me, engaged a blacksmith to force and burn it out with a red-hot iron bar. And this was the weapon ${ }^{1}$ on which I was to be dependent for my elephant! The language I used was quite unreproducible.

As a result of this little episode, it was with some misgiving that, on March 13th at 4.30 a.m. I sallied forth from Kauwa, accompanied by my boy Bella and the local hunterman. At 11 a.m. we were still prowling about some five miles from Chad, without success. Thanking the hunterman for nothing, and turning my back on him with the oath I keep specially for huntermen, I began to make tracks for home. I had barely been twenty minutes on the return journey when the latter dashed up to me, and said that he had sighted our quarry.

I turned and followed him into open country, noticing with some uneasiness that, beyond patches of grass about waist high, there was not a single

${ }^{1}$ I had discarded the $\cdot 303$ in favour of the $\cdot 375$ B.S.A. Express this tour. 
bit of cover in the shape of tree or scrub. Nothing presented itself for miles around but very light grass and the uncouth "tumpafia" plant. Moreover, I was dog tired, the sun was at its zenith, and conditions generally unfavourable for tackling an elephant.

Suddenly my guide pointed to a vague colourlesslooking mass, which so fused itself in its surroundings that at first I could not discern it at all. As I got nearer and had a look through my glasses, it took shape, and assumed the proportions of a huge elephant-the sentinel, as it transpired, of a herd of seven. Advancing still nearer I was struck by the apparently diminutive size of the tusks, and murmured to the hunterman, "They are only piccins!" He assured me that this was far from the case, and I did not then fully appreciate how great a portion of the tusk is of course concealed by the lips and embedded in the head. Besides, the Chad elephants are colossal brutes, and their bulk naturally dwarfs their tusks by comparison.

I was now within about 120 yards, crawling on my hands and knees in a small patch of grass. I asked the hunterman whether I dare try and get any nearer, for I was very exhausted, having been over seven hours on the move, and wanted everything in my favour. He knew very little Hausa, however, and I evidently did not convey to him what I wanted to know. He merely got very excited, and began the usual "Gashi! Gashi!" 1

1 Vide Chapter IV. 
Being afraid that he would lose his head and give the whole show away, I got into a kneeling posture, and drew a bead on the big bull, who was slightly in advance of the herd, which stood in crescent formation on my right front. I fired, and-whether it was exhaustion that made my hand shake, or a blade of grass that obscured my vision ${ }^{1}$ I do not know-apparently missed the whole target! I could have torn my hair out by the roots, or committed any other form of self-mutilation.

Throwing up their heads they ambled off, and disappeared in a depression of the ground, to reappear shortly afterwards in an almost identical position on my left flank. I was now at a disadvantage. They were much closer togetherand so harder to distinguish-suspicious, and on the move. Worst of all, I was to windward of them. Not daring to delay matters, lest they should clear off-or do something disagreeable-I waited till the big bull showed his head in front again, and took a steady aim (standing this time) between the eye and the ear. The bullet struck home, and he dropped stone dead, and never moved again.

I was not, however, immediately permitted to go and sing Nunc Dimittis over the dead, for the living now engaged my attention unpleasantly. While five of the company dashed off, the seventh turned and came swaying towards me, its great ears flapping like a glorified spaniel's in the breeze. Clutching my arm the hunterman cried: "Mugu!

1 Vide Chapter IV. 
Mugu! Fada gareshi! Halbe mana, da sauri!" 1 I mumbled something feeble about the "Governor only agreeing for one elephant," but this observation he clearly did not consider adequate to the emergency, for he shouted more and more violently horrible prophecies about death and "teeth."

Obviously the brute-an old but undergrown little devil with half a tusk missing-meant mischief, so I emptied a magazine into him as hard as I could. Five shots all found their mark in his head, but not in a vital spot, and he still came on. At twenty yards or so he stopped and staggered, and a bullet through the knee-cap brought him to earth. It was a great and picturesque sight as he rolled over with all four legs in the air. I gave him a coup de grâce, and then went off to see Number One.

I was still struck with the hugeness of the frame in proportion to the tusks, but was satisfied that he was no piccin! As a matter of fact, the two ivories, when weighed later, turned the scale at $61 \mathrm{lb}$. and $60 \mathrm{lb}^{2}$ respectively, which is Rowland Ward's biggest but one for Northern Nigeria; while the circumference of the forefoot before preservation ${ }^{3}$ was within an inch of his largest from any part of the world, ${ }^{4}$ though of course there may be others larger which have not passed

1 "A rogue! A rogue! A palaverer: shoot quickly!" 2 The smaller pair weighed $47 \mathrm{lb}$. and $38 \mathrm{lb}$.: Melbourne Inman sold them for me to Messrs. Nidd, billiard-ball makers. From them I gave him a set of balls with which he has made two breaks of over 500 .

3 I.e. $66 \frac{1}{2}$ inches. There is considerable shrinkage, however.

${ }^{4}$ Records of Big Game, Fourth Edition. 

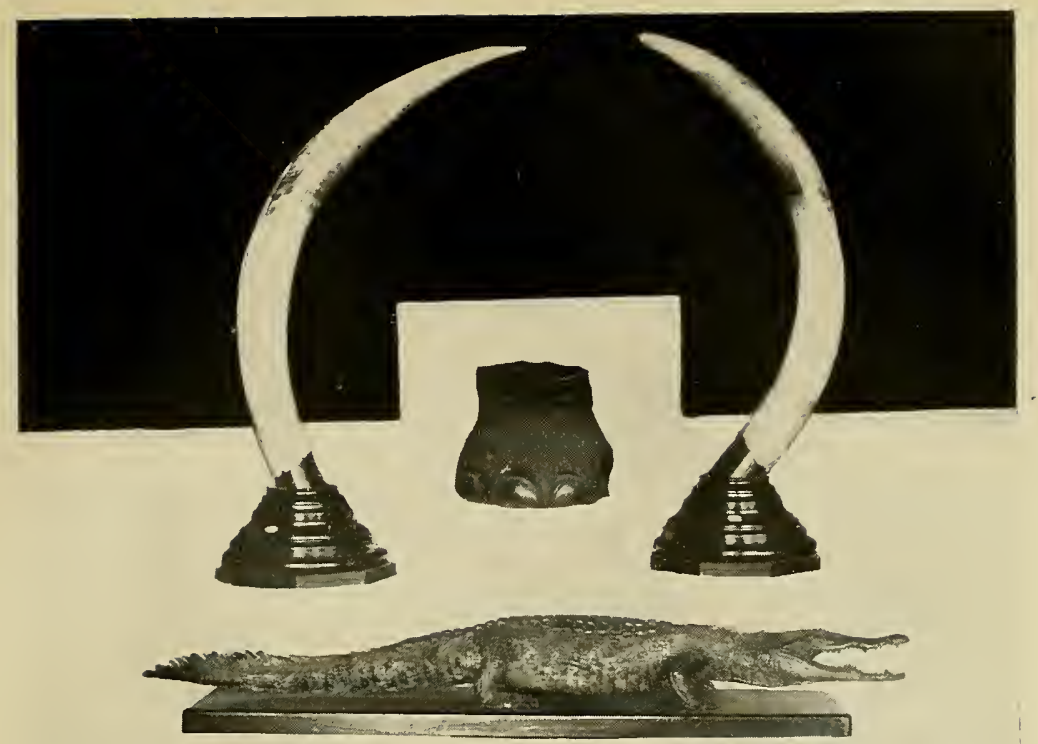

IVORIES AND FOO'T OF BIG ELEPHANT.

(Geidam "croc." in foreground.)

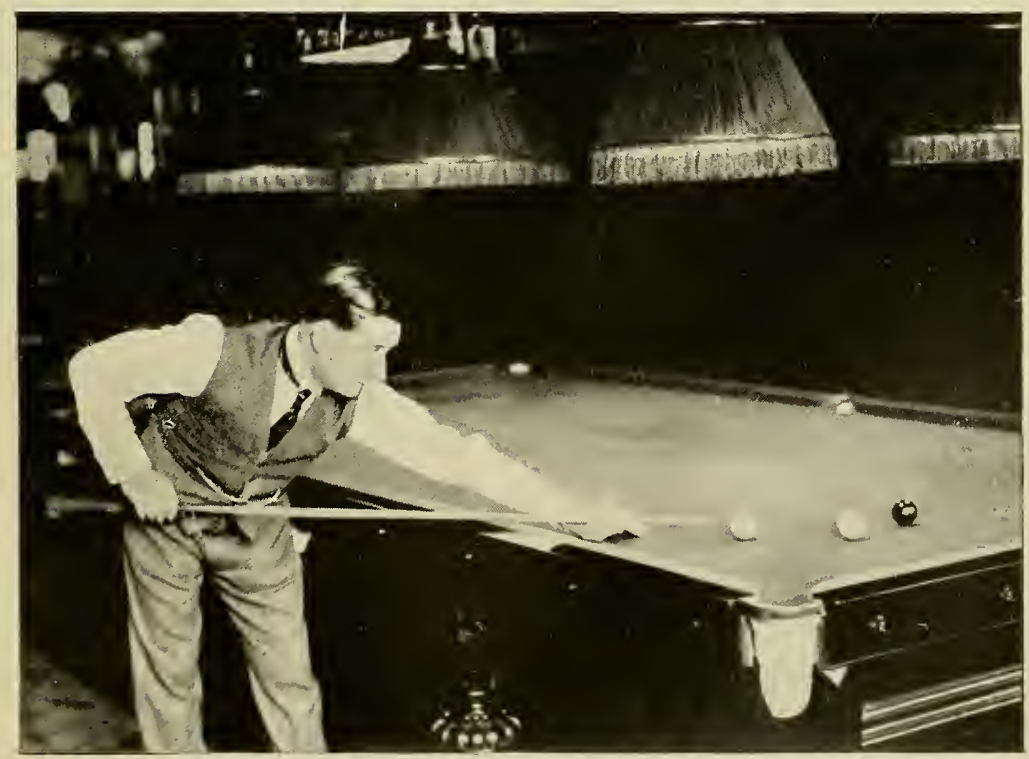

MELBOURNE INMAN AND "IVORIES" OF ROGUE ELEPHANT! 

through his hands. My three little nieces could stand inside it quite comfortably. As for the ears, I propped one up, and it afforded me excellent shelter!

I now left the spoils and went off to find my convoy, whom I had ordered to follow along the Kauwa-Seyoram road, where I picked them up about one o'clock. On our return to the scene of action, a bizarre and almost pathetic spectacle met our gaze. Over the corpse of the smaller elephant, mounting guard as it were at some solemn lying-in-state, stood two of its erstwhile mates, mute and absolutely motionless. Silent as carven images they faced us, giving no indication as to whether their feelings were those of mere curiosity, sullen defiance, or abject sorrow. Almost as much in deference to the mourners as by way of precaution, I retreated to a distance where I could watch the wake in sympathy and safety.

But news in the Dark Continent travels like lightning-especially news of meat in famine time -and within half an hour the horizon was dotted with black figures who swarmed like mosquitoes to the prospective banquet. Forming a huge human semicircle, they converged on the silent watchers, brandishing sticks and knives, yelling songs of triumph, and ever increasing in number. The mourners raised their heads, gave one look of pained surprise, as if shocked at the desecration of the dead, and then trundled off towards Chad.

Then ensued pandemonium. While the hunterman got to work with his knife on those portions 


\section{A MEAL FOR THE MULTITUDE}

of the prey which interested me-namely, the tusks, ears, feet, and tails-the oncoming masses of famished humanity fell upon the carrion. Two old women actually fought each other inside one carcass over a scrap of raw gut which both claimed. Howls of exultation, mingled with the curses of the body-snatcher, rent the miasmic air of Chad. At nine o'clock at night the hunterman had not even nearly completed his task, and, leaving him with instructions to load four bullocks with the trophies when ready, I returned to Kauwa. I was too overtired to sleep much, and in the morning was attacked by my old dysenteric symptoms, which the terrible March heat aggravated.

At 3 p.m. next day the hunterman returned with the bullocks laden with what smelt not unlike putrid cheese. When I say that long after these relics had been treated with preservatives, and familiarity had killed all sense of smell in me, ${ }^{1}$ the authorities at Reading Station (where I had stored them temporarily) wrote requesting me to remove them instantly from the station premises, and, if possible, from the town, some slight conception may be had of their perfume in the glory of their freshness! Even now my mother affects to have an attack of faintness when she passes the ear of the big elephant, fitted as a table to seat five!

Not least interesting of my mementoes is the

1 They were placed for safe custody in the Rest-house where I slept, every night, between Maiduguri and Kanoa journey of twenty-four days! 
hard-nosed bullet, which, after passing through the brain of the first victim, was recovered from a back tooth. Proudly, but far from fit, I returned to Maiduguri.

In May or thereabouts Von Raben passed through en route for Mora. He was the German Resident, or equivalent thereof, a good sportsman, thoroughly British in his point of view, and a gentleman in the best sense of the word. We initiated him into the excitement of polo, with which he was much impressed, and the same evening Tamsie gave a dinner-party at which we were charmed by the vivacity and camaraderie of our guest.

Next morning he asked, and was allowed, to be present at an interview with the Shehu and the Shuwa sheikhs who had just been summoned to a ceremonial meeting. Being not unlike Hewby in face and general appearance, I took the opportunity of having a dig at the chief sheikh, telling him that this was a German "Mista Ibi" (this was a pre-war statement, and therefore not actionable!) who would be watching them closely from the German side when they did their annual dodge from British to German pastures!

Next day he left us-not before he had invited us all to visit him at Mora in August, when the river would be high, and his abundant store of good fare would have found its way up there. Sure enough we presented ourselves in August, but not alas! as welcome guests. The last of all the enemy to surrender, from beginning to end he conducted himself as a gallant and worthy 
foe. His kinsmen on the Western front were as different from him in the rules of chivalry as the assassin from the Crusader.

The Political Officer has grown accustomed to being made a jack-of-all-trades, and I therefore showed no surprise when I had the supervision of an ostrich-farm added to my countless duties. The farm was about as successful as most Staterun enterprises. French experts having failed under favourable circumstances in the north, it was not likely that an amateur was going to achieve success. At any rate, I got through a "plucking" without accident. But the net dividend amassed from this venture from start to finish was one egg, excavated from the body of a dead ostrich, which I converted to my own use, and to the entertainment of my friends, in the shape of buttered eggs for four days!

Time passed uneventfully (God knows it was to be eventful enough later!) with polo the chief attraction, and de Putron, who, when he first came, could barely sit a horse, an almost firstclass exponent of the game. Polo days generally ended with a little tête-á-tête dinner with Tamsie, whose conversation was as stimulating as his cuisine.

De $\mathbf{P}$. had built a real good house, with fly-proof office and mosquito-proof sleeping-room, but was transferred to Geidam before he could enjoy the benefits of it, which therefore accrued to me.

At the end of July I was posted to Geidam in my turn to relieve de $\mathbf{P}$. On my way there I stopped at Burgo, and to my great satisfaction 


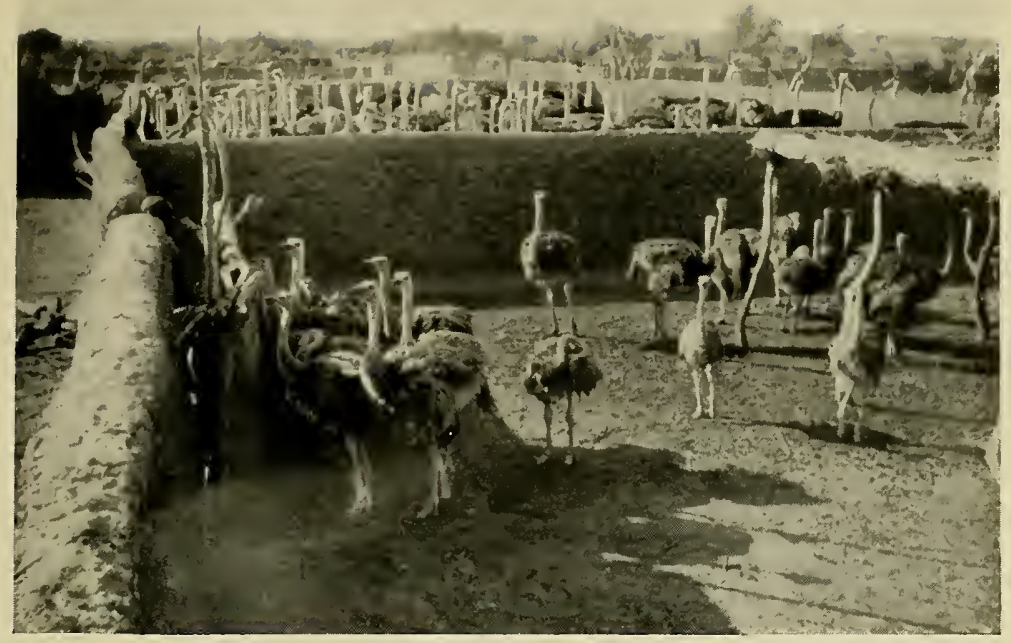

THE OSTRICH FARM.

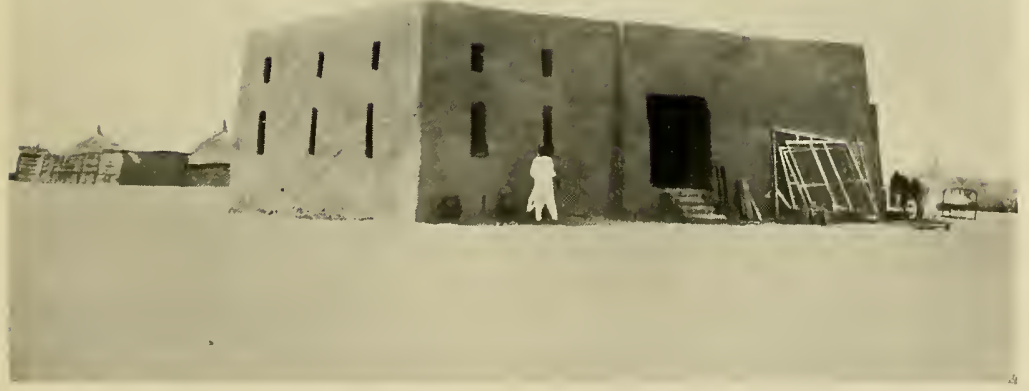

DISTRICT OFFICER'S HOUSE, MAIDUGURI.

(Designed by de $\mathrm{P}$, and completed by Author.) 

shot a good male "farin gindi," also a "derri" of fair size.

On reaching Geidam, I found that Captain Ruxton had arrived with his wife, to take over the province. They had driven in a four-wheeled trap from Kano, but their second pair had given trouble, and they were not looking forward to the sandy stretch from Geidam to Maiduguri. I lent them one of my single trappers, but he started kicking his companion, so I had to remove him.

Next day, August 7 th, came the momentous announcement by Poldhu, from the French wireless station at Fort Lamy viâ Maine, that Germany had declared war on France, and England on Germany. "I have the honour and joy," ran the message from the Commandant at Maine, "to inform you that war has been declared. I call God and Right to the success of our arms. Vive la France! Vive l'Angleterre!"

The station was agog with the news-very distressing news for poor Mrs. Ruxton, on top of such an exacting journey, with all her nearest and dearest upon the scene of the life and death struggle-and everybody asked each other questions and made suggestions (for the most part futile), and the air generally was electrified with excitement and uncertainty. Even the Shuwa Patrol ${ }^{1}$ was momentarily forgotten.

It had scarcely come home to us that the removal of the not specially interesting heir of a doddering emperor by an obscure Serb, news of which had

1 Any officer then on the Bornu staff will appreciate the significance of this observation. 
vaguely been conveyed to these outposts in newspapers five weeks old by the time they arrived, was to be made even an ostensible casus belli, let alone to ignite a world conflagration. Rather had it been regarded by those of us who had troubled about the incident at all as one of the regular " silly season" assassinations which are fashionable in that part of the world. Even now we scarcely connected it with the bombshell which had fallen amongst us. The British mind, unlike the Continental, is astonishingly unreceptive, and does not put two and two together, unless it is forced to.

As it was, as soon as it was grasped that war was a fait accompli, those on the spot put on their armour, so to speak, and sallied forth, just as if it were to a jolly old pagan scrap instead of Armageddon, with the one idea which characterized most of the earlier Cameroon operations, namely, of having "a good show"-such small items as co-operation, intelligence, or maps being considered of secondary importance. We muddled through, of course, as we always have, and always shall, in spite-or rather because-of the mathematical precision with which the foe gambles on forcing the future to fit in with his time-tables, instead of, as we do, adapting his time-tables to circumstances. Nevertheless, it cost us some of the best lives in the country. ${ }^{1}$

Ruxton immediately hurried off to Maiduguri, leaving orders for Foulkes (then in charge of

1 Wickham and Sherlock were killed at Tepe: Henry Seymour and Macdonell severely wounded there. Aubin, Maclear, Puckle, and Brown lost their lives at Garua. 
Geidam Division) and myself to follow at intervals. Lane and an advance party of M.I. raced me almost camp for camp to Maiduguri, and never did old "Danda" serve me better. On arrival at Maiduguri I found that Fox and Lees had already pushed on towards Mora, the new German capital of the Northern Cameroons; and there was a strong rumour current that three white Germans and two hundred rank and file were advancing on Maiduguri. We were all sworn in to the Land Contingent by Ruxton that afternoon, and in the evening he sent for me and ordered me to proceed with dispatches the same night to Fox, who was entrenched near Konduga.

I was beat to the world after my trek from Magumeri that morning-I had only had short snatches of sleep all the way from Geidam-but Tamsie provided me with a meal and two fresh horses, and off I went. I made Fox's camp at about 5 a.m., to learn that all was serene, and that the rumoured oncoming hordes were not Huns but a party of harmless Syrian traders bound from Dikoa to Shehuri. I do not think I have ever been quite so tired in my life as $I$ was that day, and at lunch with Wightwick I dropped off to sleep in the act of putting some soup to my mouth! Fraser, the doctor, whom I was not to see again alive, opened some "medical comfort" champagne, but, as is sometimes the case with this drug, owing to being kept too long in bottle, ${ }^{1}$ it was all corked!

1 I am an advocate of the constant circulation and renewal of this exccllent drug! 
I returned to Maiduguri next day, and received orders to tour the Marghi-Cameroon border as Intelligence Officer, and to arrange for supplies for the column under Vinen and Marwood advancing from Nafada. I had also to take with me for the Yola column 150 donkeys laden with grain as far as Chibok, and there hand it over to an officer from the Yola side. The rains were at their height, and getting the donkeys through breast-high swamps was a heartbreaking performance. It must have been no doubt during one of these involuntary ablutions that I contracted the chill which shortly after nearly cost me my life.

Maina, the new District Head of Marghi, was one of the most efficient natives I have ever had to do business with, and a refreshing contrast to his predecessor, Amadu Kago. He made every arrangement, and in a very short time had collected the supplies required for the troops.

At Gumsuri I felt seedy, and at Chibok went down with fever, which grew rapidly worse. Thinking I was in for merely a severe go of malaria, I called for more quinine-and was unconcernedly informed by my boys that it "done finish." I might as well have been deprived of my bed. I was six days from Maiduguri-there was no doctor there in any case, and the bearer of a note I sent in to Benton ran away en route. I dispatched another runner to Maina on the off-chance that he might have a grain or two of quinine, and he sent me four tabloids floating in a bottle of scentno doubt as a delicate compliment! Needs must 
when the devil drives, so I took a couple, and was violently sick.

My temperature having been $104^{\circ}$ for three days, and hearing that a second doctor, Pearson, had joined the Mora column, I sent a runner to Fraser asking if he could possibly take a short cut through East Marghi to my assistance. Unhappily he was killed the day my note arrived. I had been daily expecting the officer from Yola to take over the grain, thinking he might be able to do something for me, but this was a false hope, as only native police turned up.

I was now very ill indeed, my temperature hovering below and over $105^{\circ}$, and I suffered from a delirium of a night which always took the same form, namely, the disordered fancy that every time I turned over I had to turn those cursed three hundred bags of grain over with me, counting them one by one. On one occasion I had such a violent attack of shivering that $I$ was reduced to borrowing some stinking old blankets from the chief of Chibok, piled them over me, and made the boys light a fire in my hut. The rain used to dribble through the roof into the bed, and the misery of the thing was untold. When one is buried in the bush and quite alone, one needs to be perfectly fit: illness combined with solitude accentuates both.

One day the horse-boy burst in and announced that the Germans had left their station at Mubi, a stage or two away, and were within one camp of Chibok. This was pleasant hearing in my condition; but I was too ill to stir myself. Happily 
it turned out to be one of many false alarms. Meanwhile, I had had a letter from Vereker, attached to the Yola column, announcing the reverses at Garua and Tepe, and what little spirits I had left sank to zero.

On the tenth day of my illness I learned that Moiser, the M.O. to Vinen's column, had reached Gumsuri and got news of my predicament. He was suffering from sciatica himself, and wrote telling me to come in to Gumsuri in the hammock which he sent with his letter. He had, of course, no idea how bad I was, as he had not been in communication with Maiduguri. I replied that I could not possibly travel, and sent him "Danda" and the trap in case he could get to me.

That night he arrived, and, I shall always think, saved my life. I was stone deaf with the quinine which Pearson had got through to me, and wasted away to skin and bones. Moiser very cleverly put two and two together, and soon spotted what the trouble was-an incipient abscess on the liver. Chaytor arrived next day, and all was in readiness for an operation. Happily, however, my malady responded to that then comparatively new but priceless drug, emetin, and my temperature fell a little every day. Moiser's good company and confidence-inspiring treatment did the rest, and I was soon on the road to recovery and Maiduguri. At Masuba I actually developed an appetite, and told Bisalla to get out a tin of sausages, which were duly set all sizzling on the breakfast table between Moiser and myself.

"Hurry up and bring the eggs, boy!" said the 
former, as he helped himself lavishly to "sauseg," and at that moment the eggs arrived.

"Ah, there are your eggs!" said Moiser, transferring to his plate the last sausage.

My jaw dropped. "I don't think I quite fancy eggs-er-neat!" I murmured feebly.

"Well, have a little toast with them," replied Moiser cheerily, as he patted some mustard on a particularly attractive-looking piece of sausage.

"I-well, you see_—" I began.

Suddenly Moiser tumbled to the situation. "My dear old thing!" he said, "you didn't think I was going to let you eat sausages in your condition, did you ?"

But I had to be pacified with a baby bottle at eleven o'clock.

And so to Maiduguri once more, where Mrs. Ruxton insisted on providing me with every meal for a fortnight of my convalescence. What a difference a woman can make to a station, for better-or for worse! The trim little earthenware jugs and bowls, spotless serviettes, appetizing little dishes, and good red wine would have reconciled me to a perpetual period of convalescence! Every day I said I could not dream of letting her cater for me any more, and every day I succumbed to the temptation of the good things which arrived on the tray, and allowed her to feed me for "just one more day!" When I did revert to my own cook, Haji, who really was not a bad performer in his way, I am afraid the comparison made me behave very harshly and unfairly to him.

Neither I, nor indeed any of us whose lot was 
cast in those parts at this time, can be sufficiently grateful for the many little kindnesses received at the hands of Mrs. Ruxton. Never did woman conceal her own anxieties in those months of grave crisis for France more bravely, or show more unselfish consideration for others.

I was invalided as a matter of course, and left for Kano viâ Hadeijah early in October-a journey of some twenty-six days without seeing a white man. So fit was I by the time I reached Kano, where I was held up for ten days waiting for the next mail-train, that I protested indignantlybut in vain-at being sent home.

Sending Bisalla with my horses and trap back to Moiser, to whom I had sold the latter, I reluctantly embarked on the train-a fellowpassenger being the German prisoner who had attempted to blow up H.M.S. Cumberland. I caught the Burutu ${ }^{1}$ (Captain Potter) at Lagos, and we sailed packed like sardines, three and four in a cabin-one of my stable-mates being Bathgate, with whom I was destined to be doubled up on the ill-fated Falaba, of which more in a later chapter.

1 Sunk in collision, November 1918. 


\section{CHAPTER IX}

\section{HORS D'QEUVRES VARIÉS}

Small Chop is a stimulant as necessary to the jaded appetite of the Nigerian exile as the kolanut to the carrier, or strychnine to the failing heart. It is acceptable at any hour of the twenty-four. I remember Stone, on the river trip described in Chapter I, would seize a knife, and make a salad of sardines and raw onion-chips at eleven in the morning, and Bertram Wood would passionately demand buttered eggs and Heinz's tomato ketchup in his sleep. Even so has the fancy moved me at this point to ginger up the flagging interest of the reader with a few anecdotal hors d'œuvres, served haphazard, ere they slip my quinine-logged memory. [How not to set about a Small-Chop party, by the way, is to tell the boy to "pass" Small Chop-as did one parsimonious officer-and to receive the reply that the cook has gone to town with the key of the yam store!]

The following bonne bouche shall have pride of place on the platter. I had freshly taken up my duties in a fashionable division of the Southern Provinces; and the local Chief, having ignored my existence for ten days or so, had then sent me up a verbal message inquiring when $I$ was going 
down to see him. Calling up a "number-man," I mildly asked him if it was customary here for the Political Officer to go and pay his respects to the Bale, or the other way round. The numberman gave his stomach some much needed ventilation by flapping his one and only jumper gently up and down, and appeared to be at a loss. "Prafs," he observed, after a pause, "he no savvy you be gentleman, but tink you only A.D.O." A stroke of diplomacy which would have been less elephantine had not a mere A.D.O. been sorting vouchers at the adjacent table.

More artistic was the diplomacy of a clerk (rubesco referens) in my own distinguished department, who had been sentenced for larceny to six months' imprisonment. "In view of my recent transfer," he wrote to his Cape Coast inamorata, "from Political to Prisons Department, I shall be extending for a further six months. There are several others due before me, and the roster is adhered to far more strictly in this Department." "Adhering to the roster" is extremely happy.

I am undecided whether the native is more delightful in his tact or in his frankness.

Of the latter school was one, Dan Baba, who, when questioned by me on my return from tour why he had taken a second lot of dog-chop money from the doctor, when I had already made provision, replied : "Ambani-na ki-ne?" ("Does a man refuse what he is offered?")

Candour on the part of a native in many cases conceals a barb, howbeit all unconscious. 
Not long ago, we were examining certain policeconstables in Lower Standard English, and, to test the vocabulary of one candidate about which we were doubtful, Phillips asked him: "Is this examination easy?"

"Yes!" replied the weary police-constable, "—_for you."

Again observe the brutal, though quite unintended shaft of another examinee. He had been describing the various "shows" he had been through in Sokoto and elsewhere as a W.A.F.F.

"But you don't wear any medals for these scraps?"

"No, sah! Dey no give medals : no white man catch wound" (!).

Not lacking in candour was Audu Ibi, a bugler in "A" company, of whom I omitted to make honourable mention in my chapters on Bauchi. His previous calling in life, he obligingly informed us, was to stand behind trees on main routes and tap traders on the head, while his father robbed them.

$\mathrm{He}$ was also a wag. One evening Murphy Moran and I laid a hyena trap. With the help of Audu, we set a $\cdot 303$ concealed in scrub, with the body of a monkey attached by string to the trigger-catch within six inches of the muzzle. If the affair should be successful the hyena could not escape being blown to bits; and we were returning homewards, when Audu Ibi came running up hot-foot. To Murphy's inquiries as to what was the matter, Audu, with immobile face, 
but twinkling eye, replied with a salute: "You have forgotten to sight the rifle!"

Not long previously Sir Percy Girouard had presented the Emir of Bauchi with a pair of bugles; and the latter had obtained permission from Murphy for two of his varlets to undergo a course of training with the W.A.F.F. bugler. Some evenings later, Murphy and I were strolling along the Naraguta road, when heartrending cries and lamentations issued from the bush on our right. Investigations revealed Audu Ibi standing, whip in hand, over the prostrate forms of the Emir's would-be buglers, who were endeavouring to protect their nethermost parts with Sir Percy's bugles. Audu, questioned, explained in so many words that these were mere "preliminary lessons" (!) I may add that he informed me privately afterwards that what had really annoyed him was the one trying to blow down the wrong end of the bugle, the other trying to inhale at the right one!

Murphy, by the way, was nicknamed by his men "Bahagu" ("The Left-hand man"). As he played tennis, racquets, and all the ordinary games with his right hand, I could not understand the sobriquet, until Audu lightened my darkness thus:- "If you had had your face smacked by Bahagu as hard and as often as I have, you would understand!"

Murphy apparently led with his left!

Two episodes of historical importance as showing how bit by bit we built the Empire are related by a character already mentioned in these pages. 
(He has obdurately rejected my periodical exhortations that he should give the world the benefit of his thirty years' experience of joy and sorrow in West Africa; and it is the duty of the Government to subpœna him to do so.)

"I was sent out down the Coast in November '99 to engage the details of the first native 'civil staff' authorized for Northern Nigeria, and after an interesting experience, staying a week or more in each colony, I arrived in the New Year on the Niger with some scores of 'all sorts,' and more to follow.

"The task of weeding out the crowds of applicants, with their curious and diverse credentials, had been considerable. At Accra, the only testimonial produced by one of the candidates for a clerkship in the Government Service of Northern Nigeria was a paper certifying that the bearer, A. K., had been 'dismissed from school for furnication' (sic).

"Having, at Lagos, to go off and meet the newly arriving High Commissioner, and report progress, I mentioned the foregoing unsuccessful application to His Excellency, who, chuckling heavily, queried: 'Well, did you ask him what he had been doing since?

"On arrival at Lokoja I was posted to a district on the Benue, and we proceeded up there by canoe. On the morning after arrival, I got busy having the flag hoisted and the proclamation read. By breakfast time I had already dealt with the first application for the white man's justice.

"A man rushed into my office, brandishing a 
sword in one hand, and in the other a voluminous pair of crimson plush trousers. It appeared that, on going unexpectedly into his house, he had found his wife being embraced by a gentleman, who immediately fled, leaving this property behind him. Having calmed his excitement, I pointed out to the complainant that, if he retained the articles until the owner came to claim them, he would be doing a wise thing; while, if the owner never did claim them, he, the complainant, would not be doing so badly out of it : and that any recrudescence of Don Juanism would no doubt receive substantial justice at the hands of the native Chief. He went away apparently satisfied."

Talking of justice, it is a little difficult to preserve the customary dignity of the Bench, when accused, pulled up for contradicting himself, announces: "Your Warship! I am all topsytorvy to-day!" as occurred in my Court once; or, to the question Guilty, or Not Guilty? with a sweeping bow replies: "Nevertheless," and sticks to that plea, as happened recently, to the confusion of Judge Pickwoad.

And here I cannot resist the temptation to repeat Bathgate's immortal story of " Nevertheless."

It was a Wild West concert, and the M.C. had proclaimed that Miss Hetty Sorrel would sing "White Wings." "Miss Hetty Sorrel," came a rasping voice from the back tier, "is a ___ ! !" "Nevertheless," announced the M.C., after the hubbub had subsided and the six-shooters been re-holstered, "Miss Hetty Sorrel will sing "White Wings'!" 
Of the adaptability of men to circumstance the following illustration is educative.

We were on Native Administration Estimates. The Resident was a conscientious and memorespecting officer, who was careful, when making indents for the N.A., from a steam-roller down to a piece of india-rubber, on all occasions to preface the application with the pious formula : "The Emir requests, etc." Which is very right and proper-for is it not an earnest of Indirect Rule?

Solemnly we tackled item after item "in consultation with the Emir and notables." Head I evoked the most lively and enlightened interest on the part of His Majesty, and it was not entirely without a struggle that we passed this Head as it stood, and proceeded to items of more ephemeral and less personal significance.

Resident. "And does the Emir think 25 messengers at $£ 1$ would be good?"

ANSwER. "Da alberkachinka sarkin duniya zaki!". (Which may be roughly translated, "Yes.")

REsident. "Now, malams. Last year there were 20 district malamai. This year we shall be making fresh counts, closer assessments-does the Emir think 25 would be good?"

Answer (after a slight pause, during which the Emir is recalled to consciousness by a ceremonial dig in the ribs administered by the Waziri). "Da alberkachinka sarkin duniya zaki!" (For translation vide supra.)

Resident. "And Haruna market overseer-I see his wages are 30s."

EMIR (brightly, and with a view to neutralizing any impression which may have been created by the Waziri's action). "Ah! I think Haruna should be raised 10s." 
REsideNr. "Oh, well, but-I don't think Haruna has very much work to do, has he?"

EMIr (instantly, and finally dispersing any lingering suspicions as to his attentiveness). "Ah, to! Let us cut him 10s., then!"

And with a weary sigh the earnest Resident passed to Works Recurrent.

Equally strict in the observance of Colonial Office Rules and Regulations, but from different motives, was a Political Officer, by name Mac'Topper.

Mac'Topper was annoyed generally with the Powers that $\mathrm{Be}$ : in particular they had in a recent M.P. spelt his name with one "p." $\mathrm{He}$ sought revenge. Now the Powers that $\mathrm{Be}$, are in a strong position-for they have, what MacTopper was determined to have, the last word. For a month or more he kept his own counsel; and then one day he "had the honour to apply, in accordance with Colonial Office Regulation, No. — of 1-1-18, Cap. — to be allowed to spend part of his next leave out of England."

Rung by rung his application was formally passed from Resident to Asst. Sec., to Chief Sec., to Lieut.-Governor. "Yes," minuted the L.G., "but please let Mr. MacTopper state where he wishes to spend it." Down the great ladder of officialdom to vile earth again came the M.P., and upon it with impious finger did MacTopper thus reply :-

Resident.

In Scotland.

G. MACT.

And that, we believe, was indeed the last word. 
Some of the good old crusted M.P.'s of Zungeru days contain much that is succulent. One little passage of arms between two great men I may be permitted to quote, for all the parties concerned have long since laid down their portfolios. The Postmaster-General, who in his youth had been called to the Bar, had crossed swords with the Attorney-General on some technical point. "I have yet to learn," minuted the A.-G. to His Excellency, "what are the qualifications of the P.M.G. to express an opinion on this matter." "The same," replied the P.M.G. on receiving the M.P., "as the A.G.'s-those of a briefless barrister."

The quasi-literate species of native provides quite a fund of amusement. His effusions on paper are enormously entertaining-out of office hours. I say out of office hours, because the effort to elucidate the point of some of these epistles during a glut of work is rather irritating.

Volumes could be filled with the sort of letters I mean. Lady Clifford has amassed a remarkably representative collection in Our Day on the Gold Coast. I could add to, but not improve upon them.

Only yesterday I received a letter from an applicant begging to be allowed to

put myself under your supremacy and control. I get no sence to control myself.

Your Affectionate poor Fellow,

John Gbadaniosi.

P.S.-I am even better than this testimonial. If you employ me your work will be more and more amen.

One poor soul subscribed himself: "Your own sorrowman." 
Hermon Hodge once received, by the same mail, one letter addressed: "His Majesty, The Hermon Hodge," another :

D. O. Hog,

Taxman.

Circumlocution and hyperbole are as endemic in Africa as they are in India-or, for that matter, in the neighbourhood of Gray's Inn-and for the same reason, that the public letter-writer, like the lawyer, is paid by the folio, and spreads himself accordingly. Of good healthy drivel, covering howbeit a matter of vital importance to the writers, the following is an average example.

Sir,

With most profoundly, we have the honour respectfully to approach your very worship.

Sir, We native of — Igbara woman greatly surprise to put before you and to explain to your kind and soleute consideration.

Sir, We beg to ask you to give us your ears and with deep thoughts.

Sir, We cetizens of the country - and not denizens has the pleasure to acquaint with your kind favour to make you to understand for us, though we are ignorant and illeterate before you but not in this point, we want your help now.

Sir, From our great grand Generation the fore parents we have our very native customary chop meantime is our drink which brings the strength to our husbands the farmers more and more, and gives chop to our country aboundantly which named the - fruitful country.

Sir, This our food describing is Guinea corn which yourself can identify same by given to your horse how powerful you real seeing in it?

Sir, We native woman when cooked this Guinea corn for drink and our native men as their customary drink, 


\section{HORS D'EUVRES VARIÉS}

put in the calabash pot or bottle called Kolia with them to farm it gives them more power to work.

Sir, This Guinea corn drink called Pito gives also strength to our old aged men and women who has no teeth and strength jaws to chew food is only their chop.

Sir, This now we are not allowed to use our native fooding which will give us native and none natives cheapest food like formerly, all the coasters can witness that chops are not so cheap as before, owing to what sir, Owing to the lack of this Pito when the people cant get to their farms.

Sir, This prohibition of our native chop Guinea corn by the Government or the Authority in charge — our born country, we made to understand that it was the advise from the denizen chief of - who is not our born land man, he has determined to turn our country upside down, but we natives beg your worship to regenerate our country into former condition especial with our chop which is our drink, also.

Sir, We wish to get this our denizen chief who is ruin our country in your court to let him know who he is in -

Sir, We again beg to notice you that we shall soon want of plenty food if Railway business reach to our border therefore we need sufficient to help us in our farms that Guinea corn using in chopping and drinking as Pito. We are yours Obedient Maid Servants

A
B
C
D
E
F
G
H
J
K
L.

Pl. Sir, We are more than this numbers. 
All of which might have been expressed in four words : "We want our beer."

As with the young optimist who imagines that he has perfected his education with the attainment of Standard V (or VI, or whatever it is that they advertise in their "application,") so with a certain type of "convert" who is quite satisfied that to be baptized, and called Ezekiel or Luke, is the ultrius quo non of Christianity.

An unassuming, hard-working little carpenter of my acquaintance had diffidently murmured to me one day that "to-morrow was Good Friday." In all innocence, and entirely ignorant of the stupendous fact that he had been baptized (for the sum of one shilling) in the River Osin, I asked him what Good Friday had to do with him, or his work, and received the meek rebuff: "Sake of my name be John." No doubts, no heartsearchings, no Higher Criticism for him. His name was John: and that was the alpha and omega of it. It reminded me of myself when I was ten years old, saying to my baby brother: "There goes a thoroughbred horse!" and to his awe-struck question how I knew, replying, John-like: "'cos it has a long tail."

But optimism is not confined to the youth of Africa. A certain elderly commercial clerk, who took the bright view that half a loaf is better than no bread, gladdened his declining years by signing himself "Theophilus B. Cole, B.A. (failed)." 1

${ }^{1}$ This is even more frank than the entry of a certain officer in the Nigerian Civil Service List to the effect that, among other aehievements, he "attended the Tropical Courses at 
Again, the A.D.O. at a Headquarter office had had an infinity of trouble with his accounts clerk, who had time after time messed up the cash book, omitted entries, and generally upset the office. "Is there anything you can do?" he asked one day in despair. "Yes, sah!" came the radiant reply, "I keep wicket for the Gold Coast!"

The Railway Department, of course, abounds in hors d'œuvres. Such appeals as the following are pathetically representative.

... I have the honour to apply . . . for the post of chicket collector as a lamp-boy or guard or otherwise of work. ... If this application of mine be granted, I shall left my work undone immidiately ...

My first married woman which accompanied me to up Northern died in 1917. I married again in 1918 which since then she delivered male childs twice but they are died. The last one was in September 1920 after myself recovered from guinea-worm, which up to December last she seriously ill. On February last she resumed again, and consequently suggested by doctor that nothing but climate of Northern, not agreed with her health ...

URGENT. I have the honour to inform you that my room at Sabongeri is still unsteady. . . . There is no door, no kitchen, and a bathroom and the people I am using with is useless because they like not themselves. There is no key and padlocks supply if at all the room is well fixed, the wall is unlookable no whitewash and sealing ...

Imperial Institute-but did not sit for the examination"; and quite as effective as that of another whose dearth of distinctions led him to insert "Member of several Boards of Survey." 
And this from a victim of the Great Retrenchment :-

With a poorest condition I was beg ... . since I was retrenched out from service ... may this mine please your majesty and instruct my being resumes for God's sake. Dear Father look! and Hear! that chop Health are major for a foreigner in a strange Country. Mercy! Mercy! Mercy! on me ...

Speaking of retrenchment, a wire from Dawson to a certain station-master, which ran thus :"Retrench one porter from 19th inst. and advise me names of men retrenched," elicited this reply :"Pointsman Sanusi now commenced to retrenching." To the consternation of the District Engineer, who had to fly to the scene by special trolley to investigate whether the retrenchment were of mere human clay, or of earth from the permanent way.

The morals of some of the Menial Staff in the same Department are not, I am afraid, quite up to Standard V, as one might say. Whereof witness the following (from an injured cuckold?).

This letter concerning yourself and - who were the step father and mother of my wife, and I wish to convey this message to the prostitute who is living with you that I regret my leaving _- early having no chance to take the necessary steps with her as I had wish, and that am now difying her to come to - and assume on my wife as she had done, nevertheless . . . I shall surely see that she go in for her fraudulent tricks, so far as she said she was going to - let her proceed to meet her doom there-the payment of what she worked for by ruin my house and induce my wife to do things which she had not practised. As for you, a common ignorant, 


\section{HORS D'EEUVRES VARIÉS}

I have not much to comment, but leaving you to God and your conscience to judge. So far as you are a cleptomania, I know you have been destined to misfortunes which the railway will soon find out your games.

Although my wife has confessed your inducement to her in many awful ways . . . yet I slide over them seeing that by your own hands you shall soon entrap yourself.

You seems to forget that your father was only a Bellringer in our church St. George's Cathedral in Sa Leone, and that you were only a piece-tail, Brat with a tail shirt down to your knees assisting your father on his poor profession. A Mendi tribe besides - the most ungrateful nation in the world. . . . When I first married my wife you eat and drank (and ate) the same food that she prepared, not knowing that you were Judas. You cloth your wolf's face into a sheepskin and make our house your comfortable home, behold you were a cankerworm; but the Lord will surely revenge you for me.

... I could scarcely believe that you had been baptized so far as your action shows that of an Infidele, a scaliwag, a dead conscience brute, a raw Pagan of the worst integrity and a cruel beast of the Viper and Tigris brand. Do not worry to write me as I require no explanation from you.

... - and - have selected yourselves, and your doom is in the hands of - The 2s. 6d. she paid in Court will have a continue endurance with disgrace and woe.

It would be wise if you try and hide your secret, and if not show this letter to whosoever you like; but do not forget what you did to — who is now at — if you try me it will be your end.

\section{And this !}

Even the quarters which I was supplied by Railway Officer to be sleeping in I never slept there once owing to the station-master are not telling me the exact time which the train due here, or how many train will run, 
so therefore I have to use my day and night in the office so that he may get chance to do what he like with my wife. On the 16th he again sent me to Ojuku, as soon as I left without any doubt he call the attention of my wife. . . I shall be much grateful if the I.T.O. may beg this man to put stop on this subject, as I never marry my wife for him but for my own purpose to avoid inconveniences.

Let me conclude with two reports against drivers :-

Sir,

I wish to report the vile manner in which Driver carried out shunting duties at this Station. This Driver is not in favour of the pointsman's flag, nor will he view the Shunters signals, but remains murmering within himself. He then furiously charged the wagons with gravity of his ill will to do so, until contents, palm pots were reduced to entire emptiness.

Had I not been more active than smartness the wagon would have run to point of derailment. I trust the T.M. will kindle some warm instructions in the bosom of this Driver.

SIR,

I wish to report Driver —_ working _ train refuse to stop at signal and try to run to main line on which - train was standing.

Luckily Pointsman Ojo, long serviee man, risk his life as hero, dashed to the tumbler and threw it over, thinking to be killed. This Driver is prouding of his full speed driving that people may say oh, it is Driver — he can drive serious, ol we praise him.

All simple folk-childishly ingenuous in their troubles and happiness, and not unlovable to those who understand them. 
Not of these, let me hasten to say, is the sort of jackanapes who, when the boat happens to be sailing on a Bank holiday, and you rush into the Post Office for an urgently required parcel of clothes, asks you whether you "are not aware that to-day is a dies non; and the best I can do for you therefore is to wish you "bon voyage!",

Nor, again, the sea-lawyer who, when called upon to pay his share of rates and taxes, holds mothers' meetings and circularizes his fellowclowns to the effect that "the African Empire is at Steak, and the time has come to put our wheels to the shoulder."

Nor (absit omen!) the Demosthenes Africanus who concludes his Philippic in the Negro World thus :- " - until the world is made safe for Africans, and Africa-the fatherland-is restored to its pristine power and grandeur."

If he rwants his former pristine grandeur, he can have it-on the Bukuru Plateau (three days' run from Lagos, fare $£ 12$ (?), change at Zaria); and there, incidentally, he can effect radical economies by discarding his top-hat, and other emblems of modern white barbarity, in favour of the wardrobe of those parts, which can be comfortably carried, when not on duty, in an empty shaving-soap tin. The pristine power, by the way, which he so glibly invokes, would have probably incontinently sacrificed him, top-hat and all, over a slow fire.

For such specimens as these neither the European nor the genuine native has any manner of time or use. 


\section{CHAPTER $\mathrm{X}$ \\ THE FALABA}

ON Friday, the 26th of March 1915, I witnessed Ally Sloper win the Grand National at Aintree. That afternoon at about six o'clock, after a violent game of squash racquets, I was swimming in the Adelphi baths : less than thirty-six hours afterwards I was swimming for my life in the St. George's Channel.

My brothers, Claude and Leonard, came on to the tender on the 27th, to see me off on the Falaba's last voyage. "Remember," observed the former, a naval officer, when we boarded the Falaba, "this is not pcace-time, and you cannot be too well prepared for emergencies. Let's have a look at your place in the boats." We went to the notice-board and there found posted up-the boat lists of the previous voyage! We then repaired to my cabin, where Claude took down a cork jacket, put it round me, and then tied a knot in the correct place, so that in a crisis I should only have to throw the loop over my head instead of fumbling with the tapes. Nothing was further from my thoughts than that I should be called upon to take advantage of these precautions-least of all that I should be enabled thereby to afford a certain amount of help to 


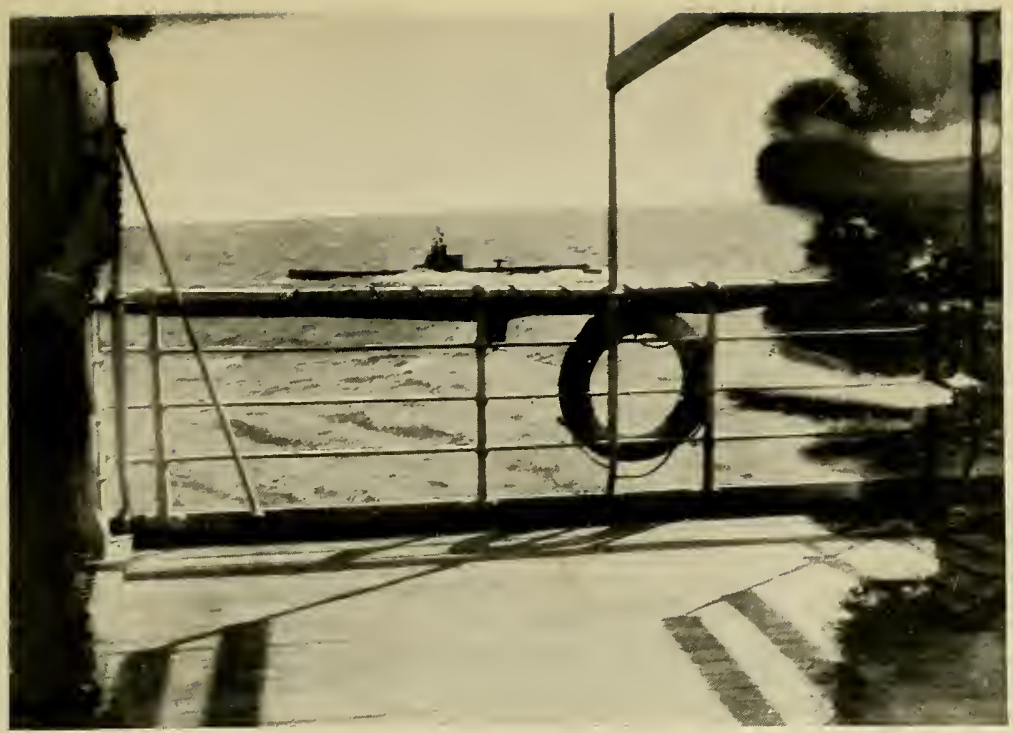

THE SUBMARINE.

(By courtesy of the Daily Mirror.)

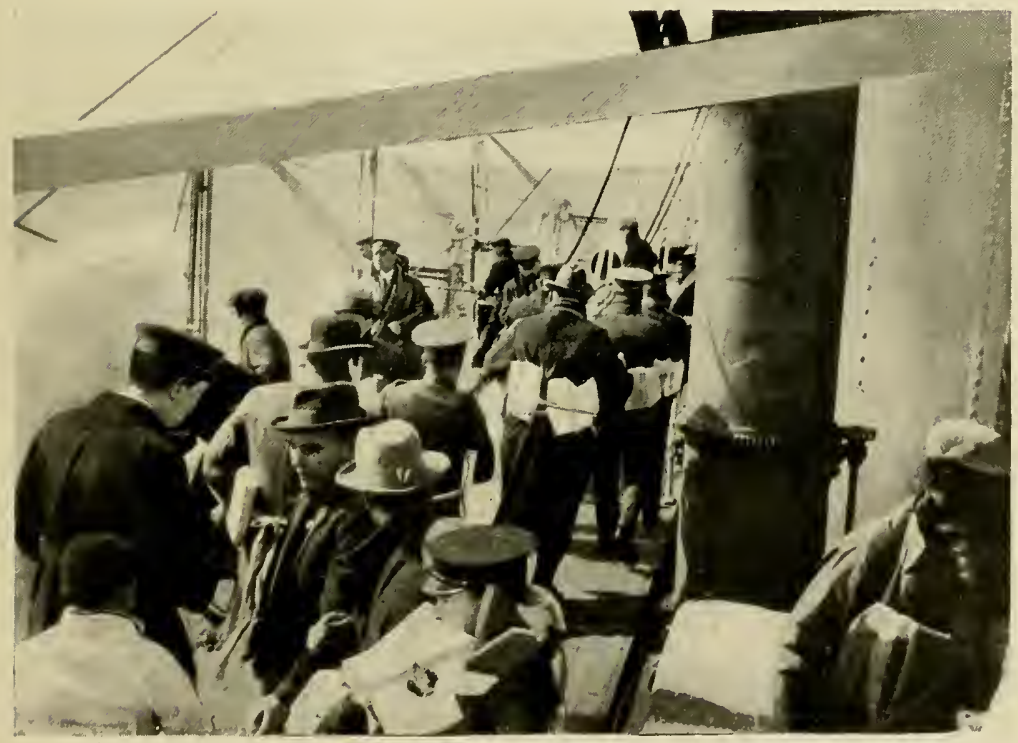

TAKING TO THE BOATS.

(By courtesy of the Daily Mirror.) 

others in their difficulties. We sailed at 6 p.m. Bathgate was my stable companion again; and, after a perfunctory meal and the exchange of a few gloomy remarks, we retired to rest betimes.

A cold grey March sky greeted us on rising, and we spent the usual first morning out trying to kill time and keep warm. The passengers are always divided into two categories at this particular period of the voyage-those who preserve a melancholy silence shunning their fellowmen, and those who assume an imitation, overacted exuberance, supported, as a rule, by dry martini's. The iatter procedure is generally known as "just having one."

At about 12.15 I was sitting in the semicircular "lounge" at the top of the saloon stairs pretending to read a book, when a doctor called Maples came in and observed to a friend: "Come and look at the submarine!" or words to that effect. Not wishing to have my leg pulled, but at the same time not proposing to take any risks, I affected to go on reading for a minute or two, and then casually strolled along the promenade deck aft. There I found a little knot of passengers leaning over the after taffrail, and peering out at a menacing object rapidly cleaving its way astern of us, and throwing up a jet of white foam either side of it. There was no doubt about it being a submarine: but there was some doubt among the onlookers as to whether it was a British or a German vessel. It must be remembered that the sink-at-sight programme had only just been 
announced, and that hitherto no passenger boat had been sunk. And the usual amiable British reluctance to anticipate trouble, till trouble announces itself, was not absent on this occasion. ${ }^{1}$ In my own mind there was no question about the submarine being a Hun, or about its sinister intention, judging from the indecent haste with which the wicked-looking craft raced towards us. Quite obviously it was not hurrying after us with the friendly information that we had dropped something overboard, or merely to cadge a piece of Benoist beef. Toiling in her wake there followed a smoking speck on the horizon, which turned out later to be a deus ex machina in the shape of a steam drifter.

I returned to the lounge, and said to Bathgate, who was half dozing on a settee, that we were in for it all right. After a hasty glance at the now rapidly overhauling $U$ boat, we retired to our cabin and picked up our lifebelts. I made some observation, I remember, about looking rather fools, to which Bathgate retorted: "Damn what we look like! Our lives are at stake." When we reached the deck again the long grey beast was right abreast of us on the port side, flying, as some said, the German-others, the British ensign; but more likely having substituted the former for the latter at the last moment. She was also flying certain flag signals of the purport of which I refrain, not being of the sea nautical, from venturing an interpretation. The com-

${ }^{1}$ Even had we been ordered to the boats, we should not have known which boats to stand to. 


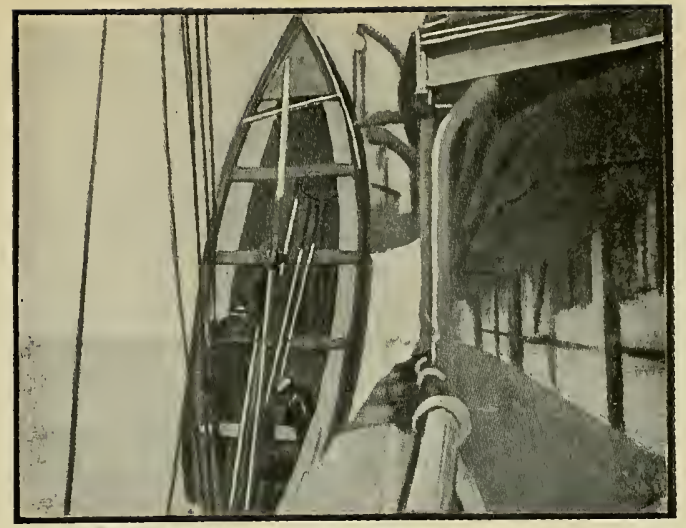

NO. 6 BOAT DIVING FroN THE DAVITS.

(By courtesy of the Daily Mirror.)

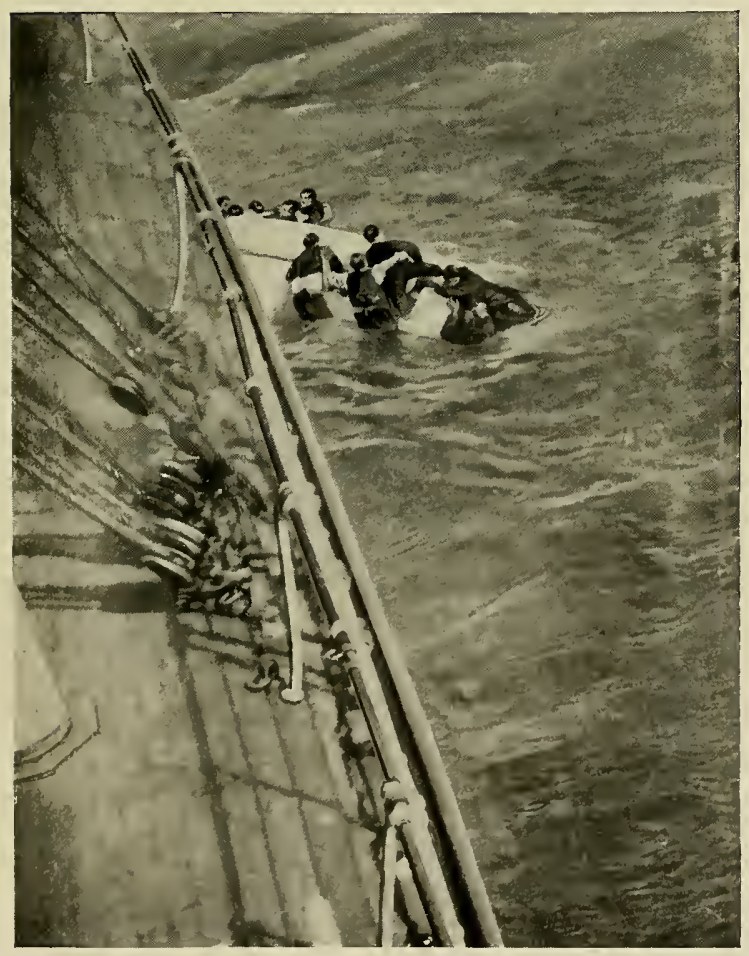

No. 1 BoAt in trouble.

(By courtesy of the Daily Mirror.) 

mander shouted something which I did not catch, through a megaphone, while "second and third murderers," as they say in Macbeth, waggled a gun at us with unpleasant significance.

It was at this point that I was able to help Bathgate and one or two others with the tapes of their cork jackets.

Then the first catastrophe took place. No. 6 boat (on the port side) nose-dived as it were from the heavens into the water, and the three occupants, according to their own evidence, went through the bottom! 1 This was the harbinger of a series of untoward launching incidents such as I shall never forget. Something next attracted my attention on the starboard side, and I arrived in time to see No. 1 boat lying keel upwards in the water. Somebody had apparently let go one of the falls with a run, and most of the occupants must, I think, have been knocked insensible or drowned straightway. One wretch was clinging to a rope, and screaming: "Rescue!" in the most blood-curdling tones.

Crossing over to the port side again, I said to Bathgate, "These boats are not for us!" And I remember his fervent reply: "My heavens, no!" Even as we spoke we saw yet a third boat-No. 2 it must have been-slowly submerging with its human cargo. As it sank almost flush with the surface it opened out, the occupants were discharged upon the face of the waters, and the gunwale floated away. Bressy, who was at our table, was one of this party; and his story

1 Vide Minutes, Q. 1175. 
is fully given in the minutes of the Board of Trade inquiry. ${ }^{1}$

We then saw No. 4 boat, crammed with passengers, slowly launched-Bishop and his wife being the last to get a place-and happily this was one of the (three) boats which survived the ordeal. The starboard jolly-boat and No. 3 were the only others to stand up. I did not see what happened to No. 5 boat, but she fared no better than the rest.

All the boats had now been launched, or smashed, bar the port gig, which was jammed in the davits, or for some reason not yet lowered. Bathgate and I went in search of the captain, whom we found on the port side of the saloon deck, waving his hand in an easterly direction, and shouting to boat No. 4 to head for the Bristol Channel.

Bathgate asked him if there were any rafts on board, and he replied: "None. And I have been given five minutes to get you all off the ship." I asked him if he could signal to the German commander that some of us were still on board ${ }^{2}$-for the submarine had now manœuvred ominously to starboard. I understood him to say that he could do so, but do not recollect his reply with any certainty. Almost immediately after this he sounded a long, vibrating blast on the siren-

1 Vide Minutes, Q. 804 et seq.

2 A futile suggestion in the light of subsequent German sea-chivalry: but these were early days, and the Hun had not as yet fully exposed his cornucopia of treachery. 
whether as a cry for help, or as a sort of Last Post for the doomed vessel, I am not clear. I only know that this weird and melancholy wail struck me as the death-rattle of a ship surrendering her soul, and made a more profound impression upon my mind than any other incident connected with that foul day's work.

The drifter, which I have said was following in the wake of the submarine, was slowly drawing nearer, and my own course of action was resolved upon from the first-namely, to cut things as fine as was consistent with safety, and not to leave the ship until the drifter was as close, and the ensuing swim consequently as short, as possible.

As I stood amidship, calculating the distance from the Falaba to the drifter, which was now about a mile away on our starboard beam, Bathgate suddenly exclaimed: "Here comes the torpedo!" There, sure enough, like a fish gyrating and churning up a trail of rainbowcoloured bubbles, it raced towards us, right through the midst of the struggling victims of No. 1 boat. Bathgate has since told me what I said at this crisis. My publisher has declined to reproduce it, though he agrees with me that it was perfectly suitable to the occasion, if not for print. A passenger on the lower deck, panic-stricken at Bathgate's warning (or my observations !) dashed for'ard screaming: "My God! The guns! The guns!" and disappeared from view. I shouted to Bathgate to run forward, for we were standing exactly over the prospective point of 
impact, and he in his turn cried: "Grip hold of a stanchion!"

We were not a moment too soon. Almost as we did so the torpedo struck the ship fair and square slightly aft of amidships. A huge column of water shot into the air ; there was a resounding crash of crockery! Doors, chairs, mail-bags, and every sort of jetsam were belched forth right and left; and the ill-fated gig and its occupants were blown from the davits into the sea. The Falaba took an immediate list to starboard, and it now became only a question of how soon she would go to the bottom.

Bathgate went off to look for a life-buoy, and I crossed over to the port side, where curiously enough were grouped three of our table companions ${ }^{1}$ - Francis, Goulden, and Trousdell. Francis was very angry and suggested that any of us who had rifles should get them up and have a final fling at the submarine crew, as we were "done in" anyhow. But by this heroic course, maddening as was the prospect of being drowned like rats without striking a blow, we should have lost more than we gained, and inevitably drawn down upon the boats which had stood up the full brutality of the Huns.

The ship was now listing horribly, and the captain-I subsequently saw him striking out in the water, clad in his blue overcoat, with his left arm circled by a life-buoy-had realized that nothing more remained to be done. The vessel's

1 The seventh-Silcock-I never saw throughout, and fancy he must have been drowned early on. 
hour was at hand, and I remarked to Trousdell : "It is time we were going." He replied: "It doesn't much matter what I do: I can't swim." He said this quite calmly, and it was like him, for any sort of fuss was foreign to his nature. I had got to know and admire him very much during the homeward voyage. I imagine that he went down with the ship, and it is to be hoped that it was all over quickly: for he was very delicate, and would never have stood the exposure in any case.

Either Pearson or Lacon, ${ }^{1}$ I forget which, had just started to slide down one of No. 4 falls, and I followed him. As he took the water I asked him if it was very cold. "Cold? My God_-!" he called back, but further immersion took his breath away. He was right. It was hellish cold! And West Africans are quite the wrong sort of people to be thrown into water of that temperature in March.

Personally, at no time enjoying good circulation, my hands went instantly as white as snow. As the ship, from where I was, assumed an aspect of relative comfort and stability, I shouted to Bathgate to throw me a rope so that I could stand by for a bit until she looked like settling. He threw a couple to me; and that was the last view I had of those actually left on the liner. Among them were Goulden and Henderson, ${ }^{2}$ neither of

1 This officer afterwards had an interview with H.M. the King.

${ }^{2}$ Henderson had apparently first of all taken to the boats, but changed his mind (or been upset) and returned to the ship again. 
whom I ever saw again. I endeavoured to cling to a rope, but my fingers were so numb that $I$ literally could not feel it in my hand. I therefore decided to face my fate, swim round the bows of the ship, and strike out for the drifter, which was now about three-quarters of a mile away to starboard.

For some reason I had not bothered to divest myself of any impedimenta, and was dressed exactly as I had been at the Grand National, spats and all! My heavy great-coat, though it may have hampered my progress, undoubtedly kept in a good deal of body-warmth, and so modified the miseries of exposure. In less than five minutes from leaving the side of the ship I instinctively looked back, and saw the poor old Falaba poise herself on end, hover, and then dive stern-foremost to her grave. It was a pathetic and almost human spectacle. One could not help feeling more than an impersonal pity for her, murdered as it were in cold blood, innocent, unarmed, and without a chance of defending herself.

The soul-piercing wails of those who but a few minutes before were cracking jokes and drinking beer careless of the future, and were now making their last distraught appeals to their Maker; the gurgles of the drowning; and the grey-looking corpses flopping and bobbing aimlessly past me, as inane and lifeless as the mammie-chairs, furniture, and casks with which they were intermingled, all added to the physical nausea caused by the roughness of the water. Foaming sea- 


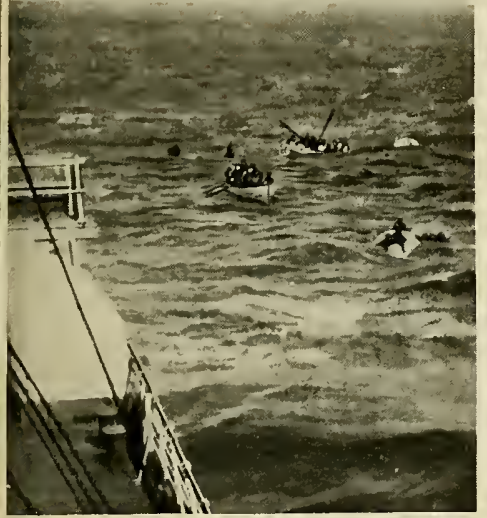

MORE TROUBLE.

(By courtesy of the Daily Mirror.)

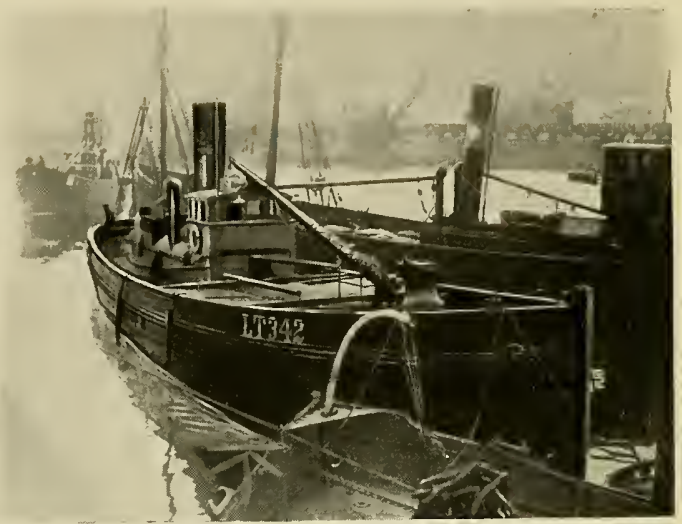

THE STEAM DRIFTER EILELN EMMA.

(By courtesy of the Daily Mirror.)

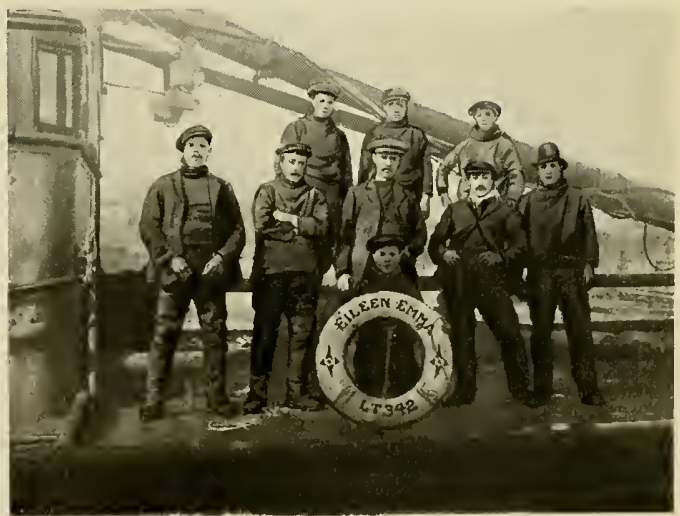

THE CREW OF THE EILEEN EMUA

(By courtesy of the Daily Mirror.) 

horses were chasing each other in endless succession, and great green billows rose up like walls, struck one in the mouth, and then hurtled one into the trough again. Never, strangely enough, did it occur to me to nurse my resources and wait till I was picked up. I was obsessed with the idea that I must either make the trawler by my own exertions, or go under.

I therefore kept swimming for all I was worth, and had got within hopeful distance of her when, to my horror, she swung round and went off in a north-westerly direction-evidently attracted by the cries of other wretches.

I was now utterly exhausted, I had swallowed a fair portion of the Irish Channel, and my legs felt like lead. Pushing feebly forward for a few more strokes, I decided that it was all up with me, and was actually beginning to undo the tapes of my jacket so that the end should not be protracted, when I espied pushing off from the trawler a dinghy containing two men, who started to row in my direction, picking up survivors on the way. I made one more sickly spurt, waved my hand, and shouted. Providence was on my side: one of the men saw me and waved back. After moments which seemed (as the novelists sayand rightly) like hours, this gallant little cockleshell of a boat drew level with me.

"My God! Bill," said one of the two men to the other, as I gripped the side of the frail craft, "we shall never get him in!" But you must!" I shouted convincingly, "tell me what to do!" (for I was past helping myself). 
The difficulty was that, with such a sea running, unless the dinghy was kept head-on to the waves she was almost bound to capsize. How he managed it I never quite knew-but "Bill" suddenly told me to "kick up a leg," which I did-or rather allowed an inert limb to float on the surface-and, letting go his oar for one sharp moment, he levered me up and into the boat. There I lay on the bottom, and for the moment could scarcely bring myself to believe that my rescue was a matter of reality. But when I saw the sun peep out and smile from behind a grey cloud, my faculties gradually returned to me, and soaked, sick, frozen, and exhausted though I was, and pillowed on a corpse, never did life seem so desirable to me, nor so worth clinging to. As for the two driftermen, with a dying man mumbling the Litany in the bottom of the boat, another vomiting over the side, and a demented nigger howling to Allah in the stern, not to mention the imminent danger of capsizing, they were as cool and casual as if they had been rowing a pleasure party at Margate. I feebly offered to take an oar! The offer, fortunately for all concerned, was treated with the contempt it deserved, Bill giving me one look, and remarking to his mate that "it would be a nice job if they were upset!"

I was eventually hauled up on to the drifter, Eileen Emma by name, and the first person I caught sight of was Kent, faultlessly dressed, with bowler hat slightly tilted, and pacing the deck with the same expression of indescribable boredom which characterizes him during any voyage to West 
Africa. His whole attitude seemed to say: "My gloom has only been temporarily interrupted, but not in any way increased or lessened by this vexatious occurrence."

I half crawled, half fell into the grimy hole which is called by courtesy a cabin on these vessels. A diminutive fire was sputtering there, and at it sat huddled a half-drowned Krooboy, exclusively absorbing such little warmth as was emitted therefrom. In justice to this coon I must say that he made way for me, and propped me up while I shed my wet garments and donned an old shirt and a pair of socks lent me by one of the crew.

Having asked the cabin-boy whether there was a tot of rum on board, and receiving the unkind rebuff : "No spirits on this ship! Be British!" I threw myself with chattering teeth on to a bunk let in to the side of the cabin. Stretched upon it lay the night-watchman of the Falaba, and, for our mutual warmth, we embraced each other, to be joined shortly by yet a third shivering bedmate.

The next few hours were passed in a state of stupor, and I took no account of time; but I believe it was occupied in cruising round in search of survivors. At about 8.30 p.m. there was a crash, and it seemed as if our side had been stove in. (According to one of Rudyard Kipling's, or Alfred Noyes's articles on the rescue-work of trawlers, published subsequently in the daily papers, we made water badly, and were in considerable danger.) I remarked to the nightwatchman that, torpedo be it, or mine, I was 
going to stay where $I$ was-to which he fervently assented! It was neither, as a matter of fact, but a British destroyer which had spoken us and come alongside none too gently.

To her we were all transferred, save the dead, in the space of about five minutes-and a relief it was too to feel that the British tar had now taken charge.

I was put on a bunk in the dynamo-room, and it was here that I first heard some details of the Huns' work. Captain Davis, I learned among other things, though alive when picked out of the water, had succumbed almost immediately afterwards. Of Bathgate there was no trace. A complete first-class stoker's outfit, a dock-glass of rum, and the 22 knots p.h. dash into Milford Haven, soon transformed me from a quasi-corpse into an exhilarated and hungry man. The pride of the crew in their ship and in their gunner was also a tonic. As we stood on the quay at 11.30 p.m., and the destroyer cast off, three cheers rang out for the Commander, and the inevitable "Tipperary" followed.

We were accommodated, most of us, at the Lord Nelson Inn, and, after some official demur, the liquor regulations were waived in our favour. Never have I enjoyed cold beef and pickles so much in my life. As we sat round the fire "burying," among others, Bathgate, and waxing enthusiastic over his epitaph, in walked the "deceased," having been rescued by the S.T. George Baker, in whose cabin he had been holding solemn requiem for $m e$ in similar fashion! As we both agreed, 
we should never have such nice things said about us during our lifetime!

He had been rescued in the first instance from the water by the returning No. 4 boat-the only boat apparently that did return, all honour to the third engineer (?)-and straightway collapsed therein. "After that," as he put it, "I did not care who won the bally steeplechase!"-a by no means inapt allusion to the premier steeplechase of the Turf, which had been run two days previously.

Some dozen of us slept, or endeavoured to sleep, on the sitting-room floor. The amount of struggling, swimming, and general "reconstruction of the crime" which took place in our disordered dreams was uncanny.

Next morning Bressy and I went down very early to the docks to recover some of our things and to thank our rescuers for all they had done for us. This last small act of gratitude seemed to have escaped the consideration of the majority of passengers in their anxiety to catch "the first train to Town." The cabin-boy was up and busy, and treated me less unkindly than on the previous occasion! He even made me some tea. But when I had recovered my money from my dank garments, and asked him to find "Bill" for me, he exclaimed: "Wake Bill! Nobody dursn't wake Bill!" However, $I$ did ; and before any really serious explosion could emerge from his lair, I had pressed some notes-undamaged curiously enough by the salt water-into his hand, and found him as tractable as a lamb. 
I shall never forget the grit of those two men, nor their modesty. I have in my possession a letter from the skipper, which I should like to reproduce, but perhaps it might be indiscreet. I arrived home late that night, disguised as a leading stoker.

Then came the burlesque at the Caxton Hall. The less said about it the better. The passengers were treated as a lot of little refractory schoolboys who had got their feet wet. The head master was the Commissioner, who occasionally, when he did not feel too bored, brandished an admonitory cane. (I thought I was going to get it once, when I could not define a "negative panic.")

The under-masters were the Shipping Company and the Board of Trade, each stoutly protected from any too plain-speaking on the part of the schoolboys by a host of counsel, one of whom-no less a person than the SolicitorGeneral-was raised to the Lord Chancellorship of England on the second day of the proceedings -possibly as a prize for the amazing effrontery of his opening speech, in which he told the Court in all seriousness that a missing plug was not a matter of great importance, since a lady was said to have kept the water out by placing her finger in the plug-hole (!). (In other words, as long as one carried a spare female about with one as well as a lifebelt, a boat with holes in it presented no danger!)

Space does not permit me to reproduce the Minutes of Evidence in toto, and to italicize some 
of the gems which fell from the lips of those who stage-managed the proceedings. The most illuminating of these, perhaps, was His Lordship's inquiry on the third day whether the chief mate, who had occupied the witness-box during the greater part of the first morning, was among the drowned! Proxime accessit was a similar question put by counsel three minutes afterwards about the fourth officer, whom he had crossexamined himself two days previously.

Mr. Dan Stephens's jaunty, but unconvincing explanation that "he had forgotten for the moment" certain questions; and Mr. Aspinall's virginal innocence in referring to "these little mistakes," the "pity" that there were no boat-lists, and "these days of competition" (Elder versus Dempster, presumably!), though faithfully following the tune set by Lord Buckmaster, were scarcely what one expects from the English Bar. Was not the evidence, by the way, of Mr. Joshua Thomas, ship's carpenter, as to the plug fitting "splendidly," just a trifle over-enthusiastic? A plug, surely, like a key, either fits or does not fit? Mr. Dan Stephens, again, can hardly have congratulated himself upon the reply he received to his question :- "But you were launched all right?" Witness : "Yes-at sixty miles per hour!"

Let me not forget to give honourable mention to one, Cotter, who claimed to represent the Stewards' Union. The stewards whom I met at the inquiry did not seem to have shrieked for, or to relish his self-allotted championship. His 
one object appeared to be to induce each passenger in turn to cast aspersions on the stewards, and then confound him, to the glorification of Cotter. As, however, we were only there to tell a plain story, and not to invent charges against people who had done nothing to merit them, his thunderous interrogatories were abortive. Even His Lordship expressed his relief when, on being informed that Cotter would not finally address the Court, he observed: "Please convey to Mr. Cotter my congratulations and thanks!" Seriously it was an insult to the witnesses-nearly all of them Government officials-to subject them to such claptrap as issued from this superfluous gentleman.

Worthy also of a certain New Bailey Judge was the Commissioner's threat to commit for contempt of court a flock of Pentecostal psalm-singers, who were making wassail in the room exactly underneath us; overlooking the fact that, having hired and paid for the room, these good people had as much right to make a burlesque of religion as had the Board of Trade of an inquiry.

Now, being one of the schoolboys myself, I, of course speak as a child. But even a wall-eyed child might have the perspicacity to suggest that, had, say, the Admiralty or Lloyds sat in judgment and examined in turn the evidence of the Company, the Board of Trade, and the passengers, unobscured by the nebulous vacuities of the legal fraternity, the procedure might conceivably have served some useful purpose. Per contra, when the two parties chiefly concerned are represented by counsel, 
whose profession, after all, it is only to put such questions as suit the interests of their clients; and when one of those clients-the Board of Trade, who are called upon to answer some pertinent questions touching the condition of the boats-arranges its own inquiry, and appoints its own president, is it likely that the third partymere amateurs, unrepresented by advocates to elicit their side of the story-is going to have much of a look in? The delightful complacency of the Solicitor-General in remarking to me during one of the intervals outside the Caxton Hall: "I hope you don't think we're being too unkind to you?" (as if $I$ were in the dock, and the prosecution were trying to let me down gently!) speaks for itself.

But if a climax to the whole business was required, His Lordship supplied it, when he solemnly announced that he would withhold his judgment until he had heard the evidence shortly to be taken at the Lusitania inquiry! If he did not mean by this that one verdict would do for both, what in the name of goodness did he mean? And, when that verdict did come, it swept aside in toto, as the imagination (let me stick to my simile) of a lot of impressionable schoolboys, the sworn, accumulative, and unanimous testimony of the passengers.

Full copies of the Minutes of the Evidence are to be obtained, among other curios, from the Board of Trade offices. I leave who reads to digest and draw his own inferences. 


\section{CHAPTER XI}

\section{YOLA AND ILORIN}

Mr next venture across the Atlantic was on the Anversville (Captain Pooley, a descendant, it is said, of Napoleon Buonaparte, and born at St. Helena). She flew the Belgian flag, having been chartered for the voyage, and was staffed by Belgian officers. A number of Falaba peoplé were on board, and some of us were pretty jumpy through the danger zone. A coal-slide in the starboard bunkers, just below where we slept, brought us out of our cabins, lifebelt in hand, in double-quick time the second night out!

The voyage was chiefly notable for the large number of " $\mathrm{K}$.'s" officers on board, most of them somewhat verdant material. In striking contrast, their table was presided over by Rupert Craven, a very tough proposition, well known in the hunting-field in my part of the world, who had relinquished, I believe, a naval career for a life of adventure and big-game shooting in the wilds, and was now a captain in the Royal Scots Fusiliers. His clothes were of the good old sporting stamp, and his blue stock would have done credit to Jorrocks. He appreciated the good things of life, and caused much merriment one night when he strolled up to an electric 
light bulb and endeavoured to light his afterdinner cigarette therefrom. "Nothing doing there, Captain Craven, I'm afraid!" said Pooley, ${ }^{1}$ who enjoyed a joke as well as any man I know, as Craven moved unconcernedly away with a deprecatory backward look, which seemed to say: "You didn't really think, my dear fellow, that I expected to get a light, did you? It was merely an experiment!"

It was the same evening methinks-but I do not suggest that Craven was at the bottom of it-that one of the young officers alluded to above appeared in the saloon just before dinner somewhere off Sierra Leone, decked in yellow mosquito boots, scarlet cummerbund, tail-coat, and sun-helmet.

At Sierra Leone, of all accursed spots, I received tragic news from home. Indeed, from now onwards the shadow of the war lay heavily upon most of us, precluded as we were from active service ourselves, and constrained to look on while our friends were giving their lives one after the other. The old irresponsible days of give and take, and free and easy camaraderie seemed to have gone for ever, and been replaced by a régime of strain and premature gravity. Inevitably, for it is the men that make the station; and nowhere in the world is the sense of association so strong as in Nigeria. Every camp one passed through called forth its own particular reminiscence, and the ghost of some good fellow who had given his life to the Cause.

1 Died on a later outward voyage at Sierra Leone. 
Nigeria has paid a heavy toll. In Bornu, in particular, I can scarcely recall an officer of my acquaintance who, if not a prisoner of war, has not made the supreme sacrifice.

I think I omitted to mention in the last chapter that those of us who had been kept back to attend the Caxton Hall pantomime only received this notification at the eleventh hour-some were actually at Liverpool about to embark-and consequently our kit sailed without us on the Appam. With the not unforeseen result. On arrival at Zaria I found I was seven loads short, including my bed. Such things are of course but a flitting detail in one's life out here; and during my cross-country journey of twenty days to Yolato which province I had been posted-I had to make do with what Kreiser very kindly had knocked up for me.

Bisalla met me at Zaria, which was a comfort, but I hardly dared tell him that we were not returning to his beloved Bornu! I was delayed nine days here endeavouring to induce the railway to transport my three horses from Kano. When they did arrive they came packed in one of those diminutive pieces of rolling-stock commonly known as "sardine-tins," in which the R.S.P.C.A. might at a pinch sanction the incarceration of one horse, but certainly not three. The railway authorities further distinguished themselves by informing me that there was no shunting-engine in steam, and that the horses would therefore have to stay where they were all night. There being no other conveyance available on 
this wonderful system, they had to continue their journey up the Bauchi Light Section in the same " mass formation." This was too much for "Dan Bekki," my prize polo pony, and south of Rahamma he very wisely elected to jump out. My cordial sympathies were with the horse, whom I found-this country, the reader may have noticed, thrives on the anticlimax-contentedly eating grass, and, as an examination by Owen the V.O., who was travelling with me, showed, none the worse. What I should like to have said to the Traffic Department I said to the doki-boy, and told him that he "could well walk the rest of the way." Which he did, and got to our destination, Buji, before the train did!

$\mathrm{He}$ did not rub it in though, as an English groom or chauffeur would have. The native is very polite, and never calls attention to the white man's bloomers. For one thing they are ton numerous. The mentality of the African is strange: his ideas of the white man's mentality stranger still. I was once studying Hausa rather keenly, and was stumped for the Hausa equivalent of the expression "I'm sorry." I found it very difficult to convey my meaning to the interpreter who was assisting me. "For example," I said, "suppose I cursed my boy for not putting the cruet on the table, and then found he had done so after all. How should I say: "I'm sorry. I did not see it before'?" "Oh," he replied (in Hausa, of course), "you would say: "Why the Hell don't you put the cruet where I can see it at once?" 
But to return to the railway. If they had distinguished themselves, the Powers that Be excelled themselves. Though the three horses had been crammed, regardless of Board of Trade regulations, into accommodation barely sufficient for one; though one of them had "alighted" before even Rahamma was reached; and though the two others had been detrained nine miles short of Naraguta, I was charged the full fare for three horses from Kano to Naraguta!

After the usual correspondence, which is the essence of life in this country, I was informed that the Powers that Be had graciously approved of my being charged the full fares, but only for the "actual distance travelled." O learned judge! A Mersey come to judgment!

This complacent remission of a debt that was never owed reminds me of a reply of Arnold Keppel, who was studying French with me in Touraine. A little over-dressed Frenchman had violently demanded satisfaction of him, and ended by challenging him to a duel. When at length he had finished gesticulating from sheer lack of breath, Keppel, with a gracious wave of the hand, replied: "Monsieur, pas de quoi. Je vous pardonne, parceque vous êtes français!"

I had a rather amusing little trek with Owen, with whom I rode from Buji to Naraguta. Here I met many old friends; and after a recherché little parting lunch with the Langslow-Cocks' in their snug hill-side bungalow, at which I was introduced (more than once, methinks) to his mellow fifty-year-old brandy, I set out for.Yola 
viâ Bauchi and Tangale. When last I had been at Bauchi, Tangale was a more or less closed area, infested with cannibal tribes, of whom my present cook, Haji, was a doughty kinsman. This country had now been opened up, and the overland road adopted by Government instead of the river route, in view of the recent cases of sleeping-sickness attributed to the Benue tsetse.

But what a road! Breast-high bogs, tsetseinfested streams, and no rest-houses (in the Yola portion) worthy of the name. "Dan Bekki" got firmly wedged in one swamp, and it took twentytwo labourers to extricate him. I had to strip and swim more than one river; and $I$ do not like to think of the breakages which occurred during these proceedings. At one of these rivers, Haji earned my undying regard by swimming across with every one of my seventy-five loads in turn. His body was completely submerged-only the load and a jet of water, spurting hippo-like from his mouth, being visible above the surface. He would not trust anyone else with them in that current. Bisalla's horse went under with him on one occasion-much more to my consternation, however, than his.

Near Yola I fell in with James Finch, returning from Garua, which the Germans had just surrendered. He did nothing particularly Finchlike on this occasion except shoot accidentally some tame guinea-fowl.

On the 21st of July, exactly a month after landing at Lagos, I reached Numan, and there got orders to take over from Edwardes, who, as 
I have said elsewhere, had completed the identical journey a fortnight before, only to have to retrace his steps all over again. Had I remained at Bauchi, and he at Numan, Government would have been saved thirty-two days' delay and a corresponding sum of money.

It was unfortunate my happening to be posted to Numan. In the course of my journey I had made some rather trenchant criticisms, in the "Remarks" books provided for that purpose, on the state of the rest-houses which came within the scope of the Divisional Officer in charge of Numan. As D.O. Numan, these animadversions recoiled on my own head! One facetious gentleman had entered the following: "As an aviary this rest-house leaves nothing to be desired." Another : "Stabling fair, but could not find resthouse."

Numan was a lonely little station on the right bank of the great silent Benue. In the rains it was almost an island, for the low-lying ground at the back became water-logged and almost impassable. There was little with which to occupy myself after office hours, and there was something about the sad, though glorious, sunsets of an evening which had an infinitely depressing effect on one's solitude.

Bisalla used to go on mysterious errands to the Mission School, and it was from a Danish padré that I first discovered that he could read and write Hausa. He had apparently been studying it quietly by himself without letting on to me! It is true that he had attended for a short 
time a kindergarten school inaugurated by the General at Bauchi. Of which a small anecdote. The General had instructed me to go to this school one evening and report progress. On my arrival Mr. Thorpe, who was conducting the class, pointed to the board and told Bisalla to read the sentence chalked thereon. The sentence in question was: "Na fada ma-sa," which is, being interpreted, "I tell him." Bisalla, no doubt thoroughly schooled at a dress rehearsal, and familiar with the meaning of the sentence, was unfortunately just a little bit too glib, and gave the show away by reading off: " $\mathrm{Na}$ gaya mashi," which, though it means the same thing, was not, unhappily, what was written on the board.

An occasional launch would be put in for fuel, and a chat with passing friends would liven things up. Fox passed through in August with German prisoners, including Duhring, the Commandant of Garua, and dined with me.

But my stay at Numan was short-lived, for within a month I was down with fever, which proved to be typhoid. My old friend Pollard. ran dowri from Yola in the Black Swan, and removed me to Yola hospital, where I lay for three dreary weeks-easily the most depressing of my life--driven nearly mad by the flies, sandflies, and mosquitoes, which abound in the Benue districts at that time of year. George Seccombe, who had been seconded for military service with the Yola column, was about the only soul I saw; and it was probably this piece of excitement, 
and a long buck about Bornu days, which was responsible for a relapse, just as I thought I was out of the wood.

Towards the end of September I shook off the dust of Yola from my feet, and Pollard took me down river in the Sarota to Lokoja hospital. My year's kit was tumbled into boxes just anyhow as I passed Numan again, and shoved on board. My relief was far too ill himself to be able to attend to them, with the result that I lost a great many things.

Two more weeks or so of sickening inactivity in Lokoja hospital, where, however, the kindness of Chartres, the Deputy P.M.O., and some excellent books (stamped "R.M.S. Akabo" and "presented to Lokoja Hospital by Dr. - ") made up for much, and I found myself posted to Ilorin for light duty. A coach was ordered for me at Baro, but did not materialize. Far from it; I had to sit bolt upright in an ordinary compartment for twenty-four hours, a "sardinetin" having become derailed during the course of our journey to Minna. Though this was about the $n$th time that this accident had occurred that year, the driver carried no jack, or tinopener, or whatever it is that the railway use for these little diversions; and a light engine had to be sent from Minna with the requisite accessories.

I duly arrived at Ilorin, and was shortly afterwards posted to Jebba, where I remained for four months. A curious place to be posted for one's health! Ilorin was a very different pro- 
position from the wilds of Yola or Bornu. One's time was almost exclusively devoted to Civil cases, auctions, and land registration. Political work and problems of Native Administration had largely to take care of themselves. The great thing was to make the Native Reservation, or "Sabon Gari," look pretty (on paper), compose solemn-reading documents "as between Ojo Ogbomosho on the one part .... and Frederick Dealtry Lugard on the other part," and in fact generally make everybody do everything in the way most roundabout and inconvenient for all concerned. A trader from the Southern Provinces might arrive at Ilorin deluded by the prospects of quietly settling down, selling some cloth at a profit, buying cattle, and returning whence he came. Mais non. He was handed a blue application form, made to attend an "auction," 1 then pay rent in advance, then stamp-duty, then a registration-fee, then a fee for plan supplied, then rates, then-but by this time he would have wisely effaced himself no man knew whither. His Certificate of Occupancy, which he had probably never even seen, would then be solemnly revoked. And so the good work, and the war, went on. The Sabon Gari-the real one, I mean, not as depicted in the plans-reminded one more of a shell-holed battlefield than a habitation of men.

Climatically I shall always maintain that Ilorin was the most temperate province I have ever

1 The "competitors" at these auctions frequently bid against themselves! 
been in. It was entirely free from that pest the housefly, and sandflies and mosquitoes were non-existent-at any rate in the two-storied bungalows. But Jebba was a very trying spot. Infested with the last two species of insect, there was also something about the heat reciprocated by the laterite formation of the hill, and a general atmospheric oppressiveness which caused me never to be really fit. Possibly the lack of exercise, and late evenings, which, however, I shall never regret, were a contributory cause of this.

There were some real sterling fellows there, including Wilian the M.O., Sutherland the D.E., Whitaker ${ }^{1}$ the A.E., and Crocombe ${ }^{2}$ the District Agent of the Niger Company. At the houses of one or other of these, or at mine, we used to forgather of a night after tennis, and forget the drudgeries of the day. And drudgery it was for some; for Weir, who was reputed to put his clock on whenever possible, had his men at work on the bridge before it was light. Dear old Crocombe's yarns, told and retold till they became "not chestnuts but marrons glacés," as the General would have said, were an unfailing source of amusement. One of them in particular was worn threadbare with us, but may be new to some. A white man had been badly bushed, and was almost in despair. The country was infested with man-eating pagans, and he felt his life was not worth a moment's purchase. Suddenly he descried a light in the distance,

1 Died in German East Africa.

2 Died May $_{4} 1917$. 

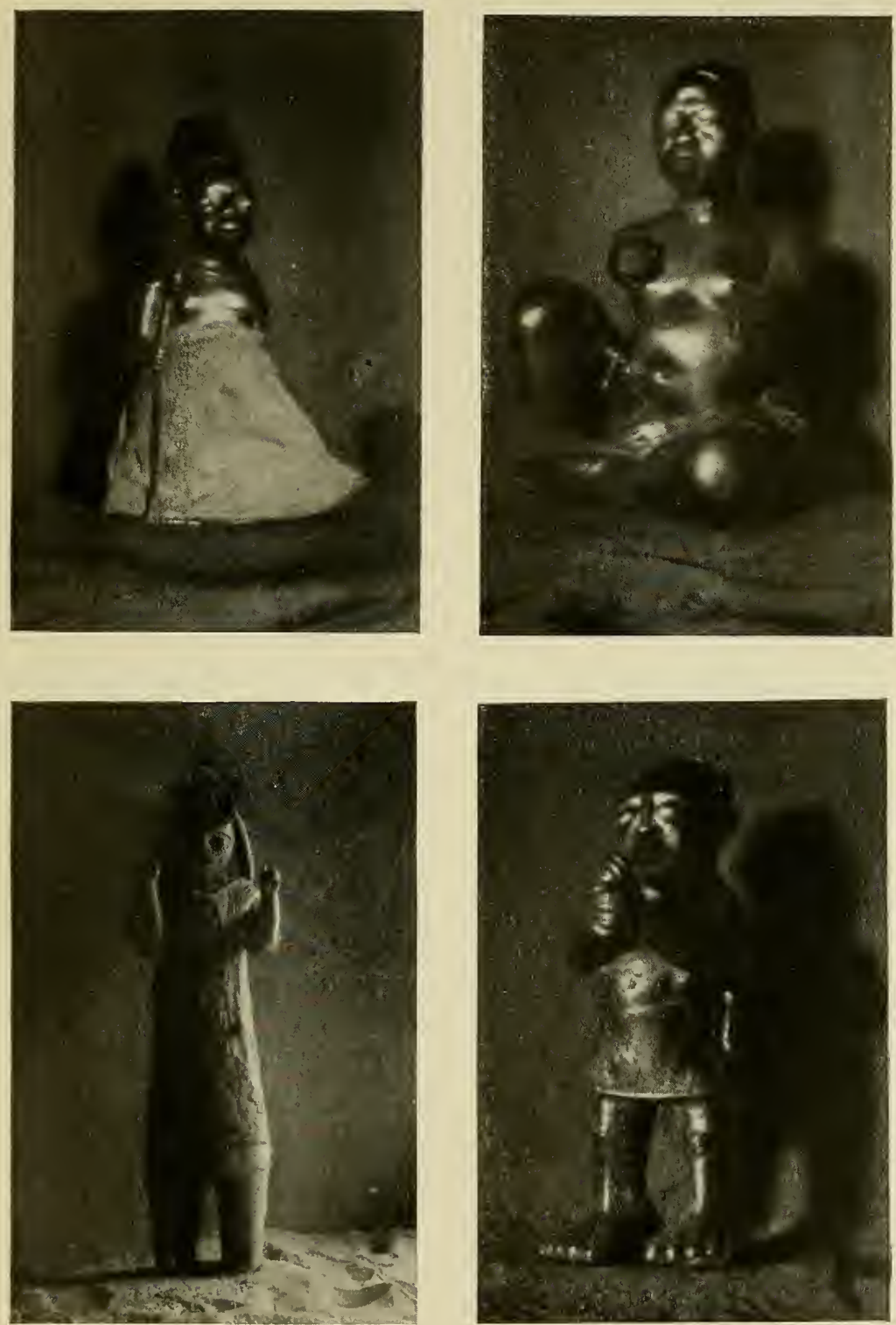

NIGER IDOLS

(Obtained with great difficulty: and at some personal risk, by the late D. Crocombe.) 

towards which he stealthily worked his way. As he drew nigh he made out voices raised in heated altercation. "If you go to bed with a _ ace," said one of them, "you can't well be surprised at being three light!" "Thank God!" cried the poor wanderer, "Christians!" His other favourite tale about "Boy! Bring my other shirt!" is too old for repetition.

Then the accountant gentleman, later "Deputy Engineer i/c Bridge Construction," used to regale us with his exploits and acquaintances at Hull. "Pleased to meet you," he would say, "I think I met your brother, or someone very like you, in Hull." Or, if someone spoke of a recent air raid over London, "they got information of that raid beforehand in Hull." Willan, with twinkling eye, would lead him on, and generally work the conversation round until there were only two possible egresses for it-either through the ramification of a Crocombe yarn, or Hull Harbour. The conversazione would be accompanied throughout by Whitaker's cavernous " $\mathrm{Ha}$ ! ha! ha!"

The Sunday morning glass of beer or "iska" -a Jebba colloquialism-either at my house or Willan's, was a ritual as unfailing as the jangle of the Mission bell. Willan, from whom I took over, had been temporarily acting as District Officer, and expressed no regret at being relieved of his political duties. His judicial ventures had not been entirely happy. They were only two. The first was an action by one lady against another for defamation of character. The evidence, taken 
down, as it was delivered, in pidgin English, became horribly involved-the principal features of the case being a salga and the legs of a duck. Judge Willan made a blind shot, found for the plaintiff, and assessed the damage to her moral reputation at five shillings. The second was a case of assault by a native on a white missionary female. What flummoxed Willan was not so much the insanity of the accused, who "proceeded to make wild statements accompanied by much laughter," as the fact that the prosecutrix declined to be sworn! This unnerved the judge so much that he forthwith transferred the case to a higher court. The lunatic $\mathbf{1}$ is still at large on Jebba Island, and entertains each passing mail train with his antics on an imaginary parade ground on the platform. $\mathrm{He}$ is also reputed to hold spiritualistic communications with the devils of Juju rock.

One of the most distressing features of life at Jebba was the "copy" wire-a channel through which the railway disseminated news of their vagaries among all and sundry, from the platelayer to the doctor and D.O. Accidents, in particular, they revelled in. So proud were they on one occasion of having run over an old woman somewhere near Ibadan, that I was awakened at 10.30 p.m. with a wire containing a long, rambling statement about "accident B." I was new to this system of "all concerned" telegraphy in those days, so I sprang out of bed and hurried to Willan's house. The latter having damned ${ }^{1}$ Since dead. 


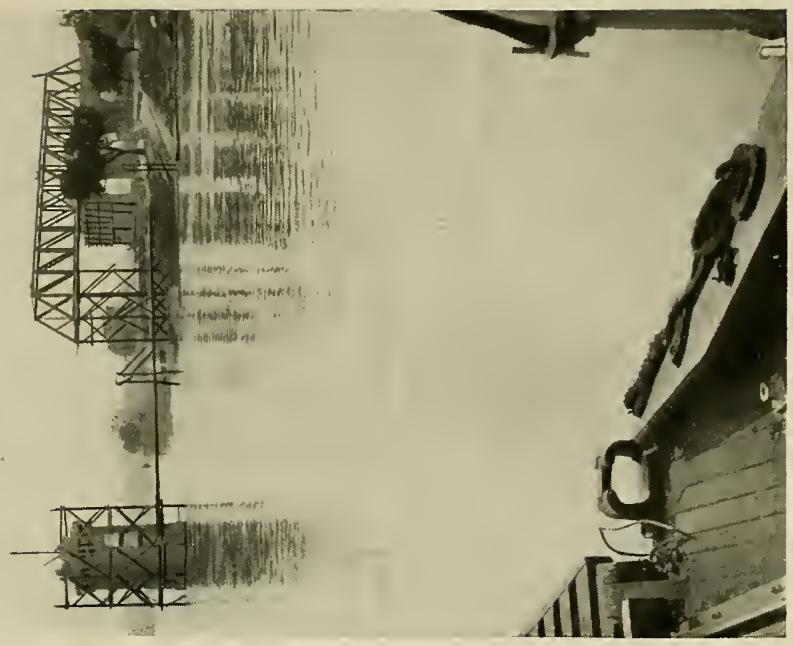


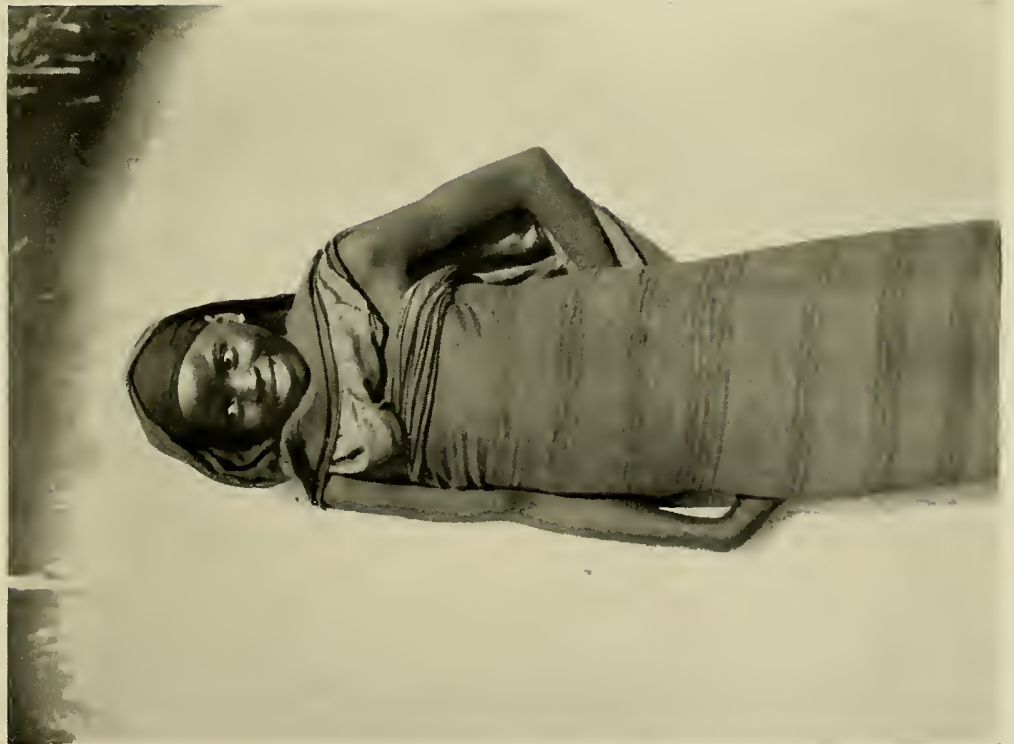

造 

me for disturbing him, explained that $(a)$ he had already had a copy of the wire himself; (b) the woman was dead; (c) there was a doctor at both Ibadan and Offa, and $(d)$ in any case it was no business of mine. Why this immense expenditure of electricity and paper takes place I have never been able to discover-unless, as I say, it is that the railway like their achievements to be as widely published as possible.

A few nights later, two gloomy-looking figures, not unreminiscent of a couple of Shakespear's grave-diggers, roused me from my slumbers, and chanted in sepulchral unison: "Pilot Marks is dead!" Never having heard of Pilot Marks, I hastened out on to the veranda, and questioned my drab visitors. They turned out to be the European skipper and engineer of the Fabiusthe ferry-boat which used to ply her erratic way between Jebba and the island in pre-bridge days. Marks, they told me, was the native pilot. Not quite knowing whether I was suspected of being responsible for his dcath, I promised to look into the matter in the morning, and off they went to convey their sombre news to the other inhabitants of Jebba.

But I was not to be left in peace. An hour afterwards I was again roused with a wire containing the usual alphabetical gibberish, and announcing that " pilot Marks died to-day, arrange." Next day at breakfast time, two more wires arrived, each proclaiming, anthem-like, the passing of the pilot. At midday came a wire from the D.L.O.: "Pilot Marks died yesterday, arrange." 
In a state almost bordering on frenzy I went over to Willan, and asked him what he gathered was expected of me. "Nothing," replied Willan, "he was a patient of mine, and the Mission crowd buried him this morning. The wires were only for your information." Somehow I felt that I could not leave it at that, for the thing was infectious. So, as I seemed to be the only person who had not contributed to the correspondence, I took up a form and wired to the A.E. (he was living in Jebba, but this is quite the correct procedure in railway circles): "Pilot Marks died yesterday, arrange." Nobody who has not lived on the line will appreciate all this: and nobody who does live on the line does appreciate it.

It was once my painful duty later on in this tour to supervise the supplying of food for troops passing through Jebba en route East Africa. Five troop specials were billed to run at specific timings. During the nine days that I was glued to Jebba platform, I received over fifty different wires containing advices either contradictory or cancelling previous communiqués. On another occasion I had five hundred calabashes of food all ready for a train advised that morning as conveying troops, en route Zinder from Dakar, who as a matter of fact were at that moment still on the high seas! The number of telegrams I received touching on this little matter are best left to the imagination.

Such was life from a telegraphic point of view at Jebba. Before I leave the subject of telegrams I must just add that a wire sent by me 


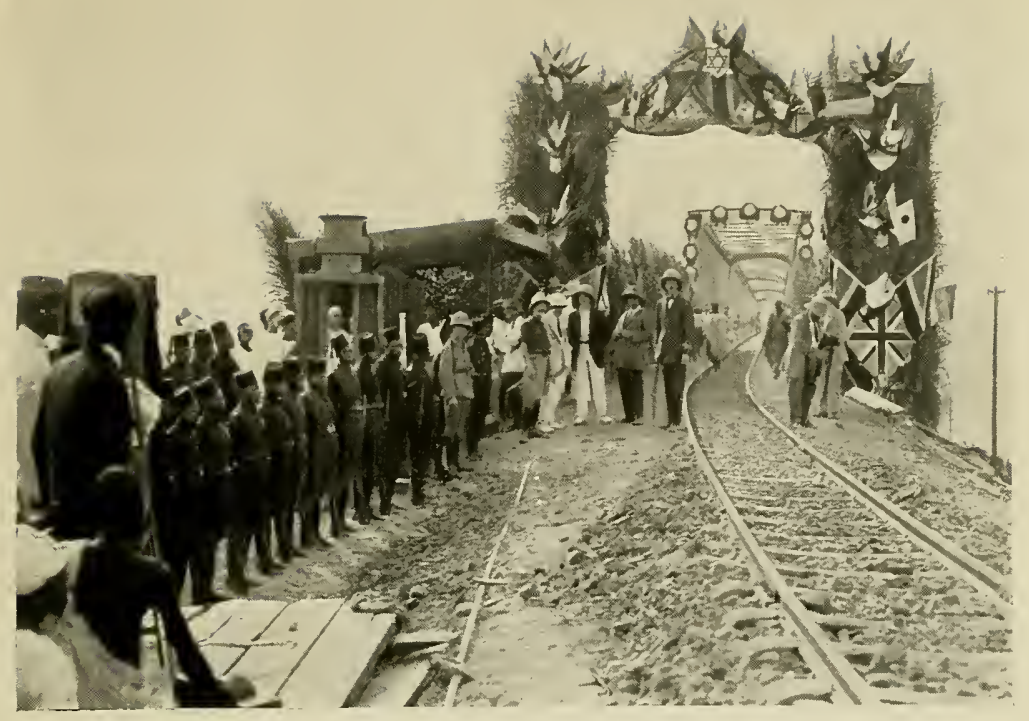

THE GUARD OF HONOUR.

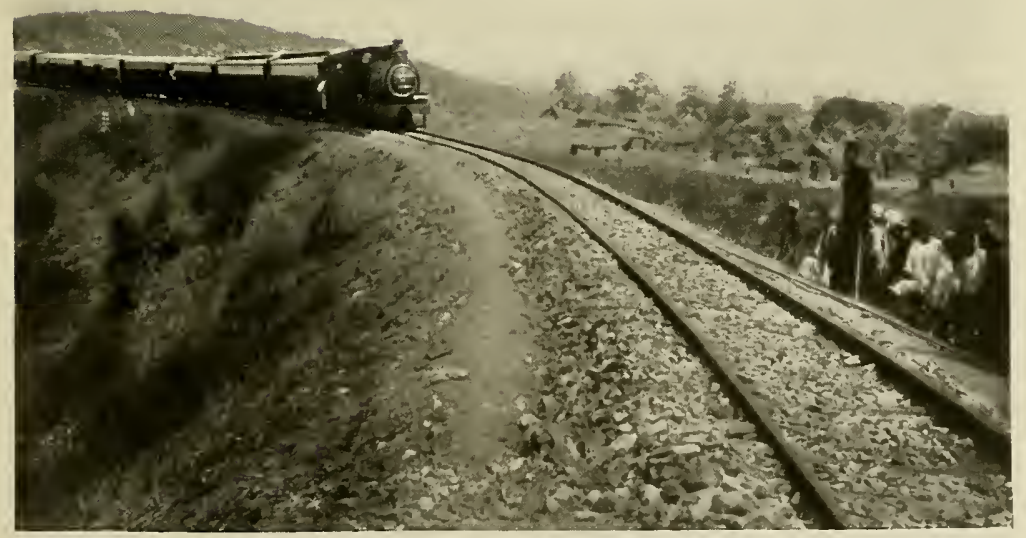



to the I.T.O., in reply to his about a court case, to the effect that it was adjourned sine die, was transmitted thus: "Case adjourned $\mathrm{x}$ since died."

A refreshing instance of naïveness may also be quoted. This same I.T.O had wired to Percy Holt, of the Niger Company, for a supply of vermouth for an individual who had been slow with his cheque-book on a previous occasion. To this Percy replied:

"Experientia docet."

"Was that damned wire of yours a code wire?" asked the former, when they next met, "or did it simply mean Nah Poo?"

"Well," quoth Percy, "it didn't mean exactly Nah Poo, but $I$ did!"

In February the bridge was opened with full ceremony. Bobbie Ellis supplied a guard of honour, the Tin Hats of the railway attended in strength, and the Governor-General performed the function. He arrived at about 10 a.m., and the train was pulled up by Sutherland at the north end of the bridge-which was just as well, otherwise Bobbie and his guard, who were drawn up across the permanent way, would have been slaughtered!

Though the proceedings were not in the nature of a gala, owing to the feared loss of the Appam, the show was made as cheerful as possible under the circumstances. Sutherland, to whom I am indebted for the photographs of the ceremony, an adept at such things, put up a wonderfully artistic yet unobtrusive display of flags, bunting, and decorations, assisted by the excellent Mr. 
Addy. The names of past pioneers, explorers and administrators of Nigeria were honourably inscribed on oak shields and hung over the northern arch of the bridge. An array of pâté de foie, caviare, cucumber, etc., sandwiches not unworthy of the cold buffet of the Automobile Club, and cigars were served without stint from a dainty table by Sutherland's boys all spotlessly decked in white and tartan. After a rambling speech by Weir, chiefly throwing bouquets at himself, and another very much to the point by His Excellency, the latter drove the first official train over the bridge in state, and, having interviewed the Emir and Chiefs, took his departure, followed by the rest of the Tin Hats. What time we repaired to a cold collation at Willan's house, and spiced viands and other good things followed-and the standard of the tennis that evening was not up to its usual high pitch.

Early in March I at length succeeded, after eight years' unsparing but fruitless effort, in shooting my first waterbuck ("gwambaza "). I had explored the whole locality round Jebba from the soul-wearying heights at the back of the station to the riverain flats in the neighbourhood of Juju rock and the islands in the lower reaches. All that had fallen to my rifle was a dog-faced baboon ("gogo ") at Isa-Ndashe. On this occasion, after sleeping at Fangam-insula improbissima!-fortune favoured me, first in the finding of my quarry, and then in the shooting of it. For the herd saw me before I saw them, and made off. Feeling somehow that I should never 


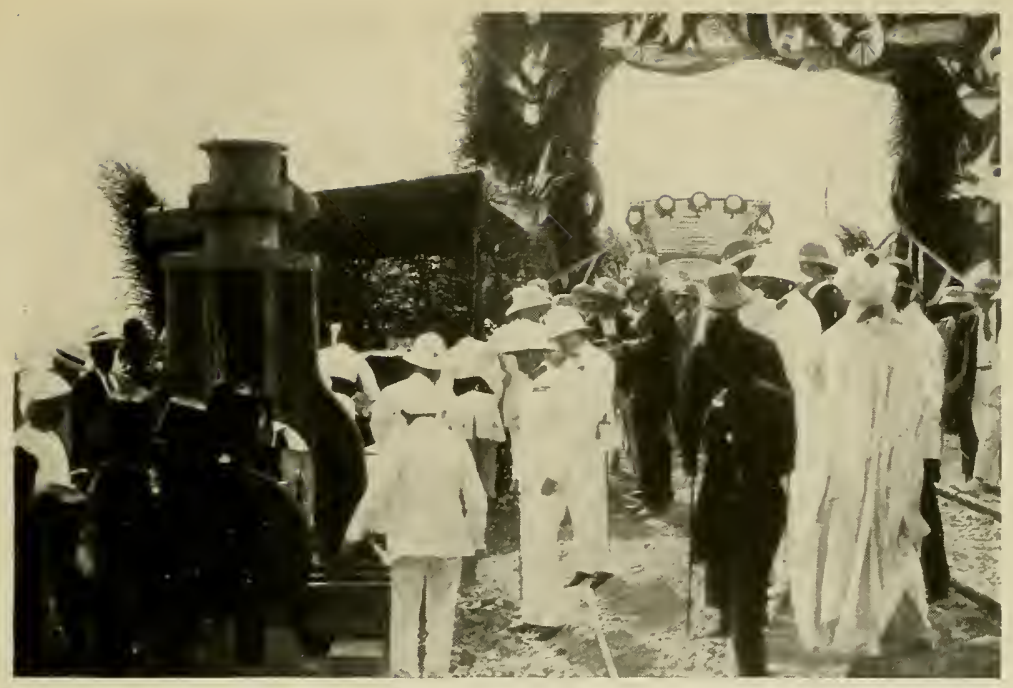

HIS EXCELLEXCY INSPECTING RELICS OF THE DAISPRING.

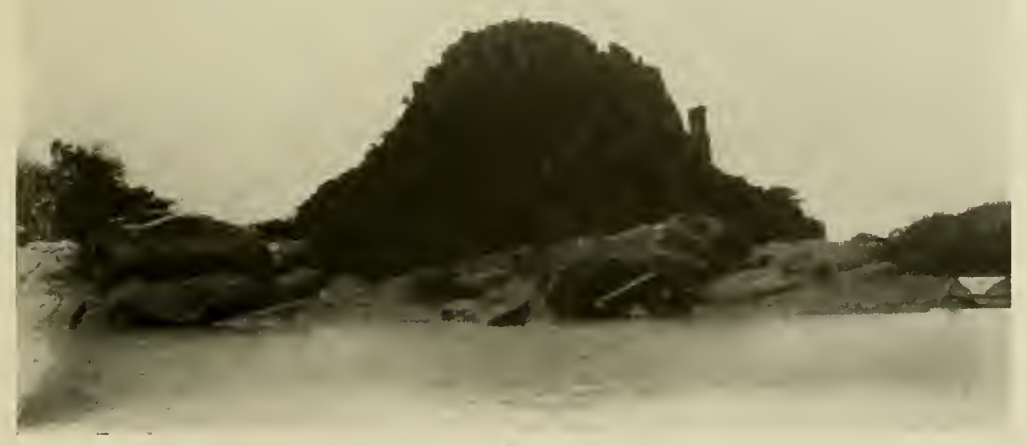

JLJU ROCK.

(In foreground remains of the Dayspring wrecked in 1857, under command of Dr. Baikie.) 

get the opportunity again, I let fly at the solitary male as he disappeared behind a bush. My exultation was great as the females reappeared one after the other on the far side, but not their lord. I had got him smack through the shoulder. The head was nothing to write home about, but a waterbuck is a waterbuck, and I had now shot all the different species of West African gazelle and antelope except the bush-buck, or "harnessed antelope" (" mazu ").

A week later I was transferred to Ilorin, Jebba being closed down as a Division.

There are circumstances, apart from the short perspective of time, which prevent my writing too fully, or too freely, on life at Ilorin at this period. Enough to summarize it, and give a few anecdotes before closing this chapter.

Tennis was the main standby, Laurence having been a half-blue at Cambridge, and Annetts being almost as fanatical about the game as he was about his "cuttings." Shooting-especially an excellent partridge stand at 7.30 a.m. behind Annetts' compound-and a jaunt to the Old Barracks for an incomparable tea with the Thorntons, were the chief other recreations. Whiteley's Pepysian wit and conversation was always refreshing, while Carmichael's dour humour was a corresponding source of amusement. Annetts'

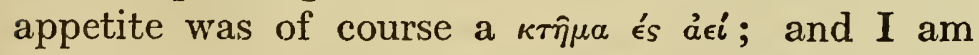
always overwhelmed with shame when I dwell upon the well-intentioned but insufficient breakfast of porridge, sausage, partridge, and eggs and bacon, which I put up for him one morning. 
Only_a few days afterwards he asked me to breakfast, not so much for the part I was to play at it, as to witness himself and Doctor Foy operate upon the meal, and to see what really could be achieved in that line.

Wood, the M.O., had a dulcitone, upon which he could perform in no mean fashion, when he felt sufficiently inspired to leave his long chair. He had a remarkable affection for this chair. Even when $I$ pinched his dulcitone under his very nose, and transferred it to my own house, he never rose from it, and the robbery elicited no more active protest than the observation that I was a "damned thief," and he trusted I would leave him the house. He had an extraordinary boy called Ojo, who used to communicate his sorrows to kind master not orally, but on paper, thus :

"Masta, name of God, I wote (sic) more pay."

To which Wood, not on paper, but very audibly : "You little swine! I gave you two shillings last month!"

Little less successful were poor Ojo's indents for what he considered the necessities of life.

"Masta, we wote tea, we wote beer, we wote champagne. Jacob Ojo."

"He seems to think," said Wood lugubriously to me, "that because I was fool enough to stand you champagne once, when I did not know you so well, it is to become a routine!"

"He is an excellent boy," I replied.

Later on Wood appears to have fallen foul of Ojo, for a year or so afterwards I received a 

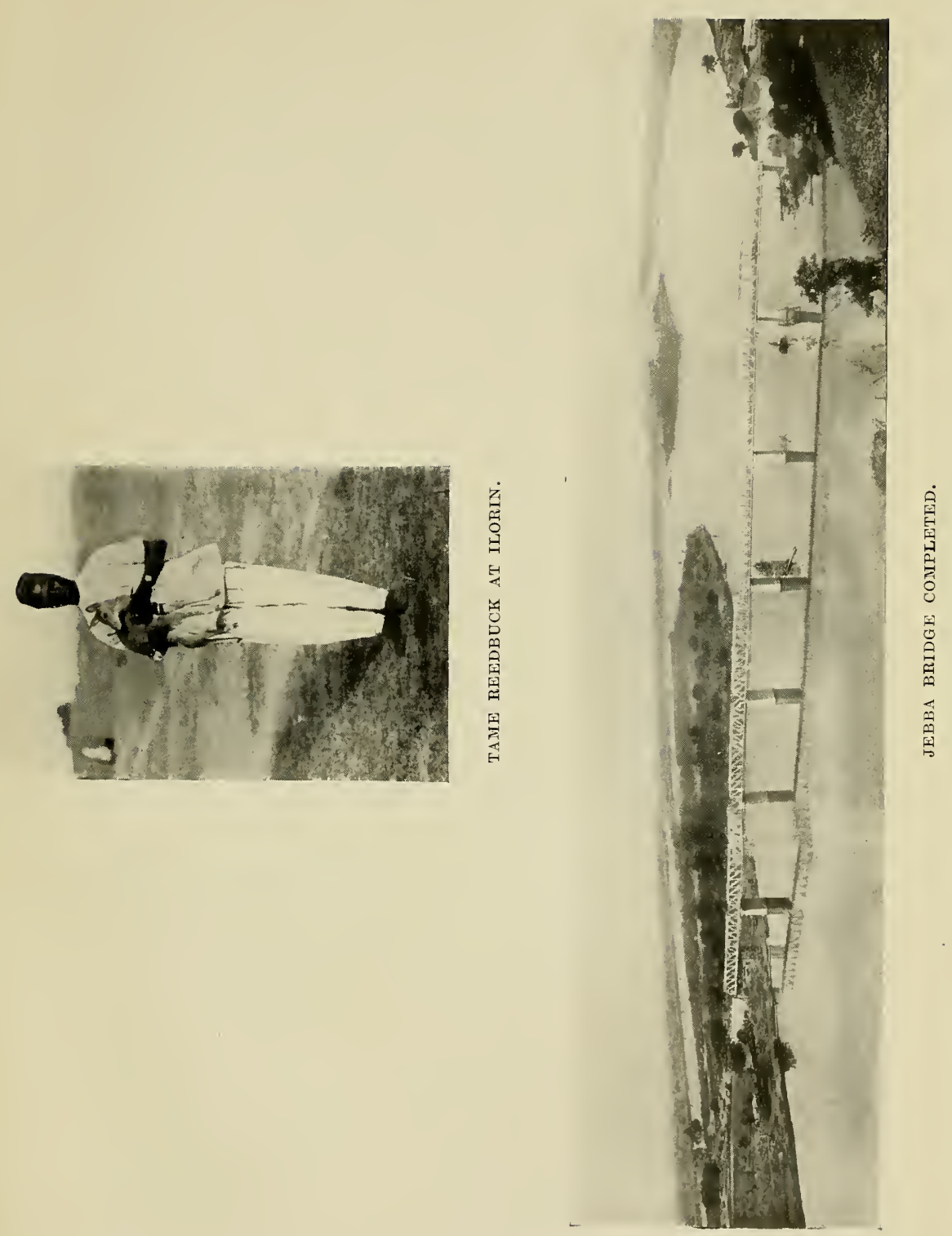

pathetic letter from him, posted at Zaria, entreating me "kind gentleman" to help him. I passed the letter on to Wood at Ankpah, who replied indignantly: "What the devil he's got to call you a gentleman about, I don't know!"

When I went on leave I handed most of my domestic staff over to Wood-incidentally informing them that their wages were increased all round for their past good services. But Wood was not to be had that way. He told them that the increase "lived for book" till the return of Langa Langa, who would no doubt pay it out!

His faithful factotum, Lawani, dispenser of drugs, cleaner of instruments, and general errand boy, used to be sacked at least once a day, or else told: "Lawani! All your pay is stopped! All, mind you, all!" but he invariably survived the threats.

Wood and I had both bought horses from the Bensons when they went home. Mine turned out trumps, but the other developed into the most appalling thing in horseflesh I have ever known. It appeared to be lame in all four legsat least we couldn't locate the sound one-and unable or unwilling to move. Its two forelegs were rigid like pedestals, and from its action, such as it was, one would have thought its legs were cast in pairs, unable to move independently. On one occasion, as we rode through the town, Wood simply sat on it, while the doki-boy pulled and tugged it after him. Another night, in the Gambari market, it began to give way. "It 
appears to require spurs," remarked Wood, as he clambered down morosely. I suggested that a grave would be more in its line than spurs; and next day it was ignominiously sold to a native. My horse, on the other hand, at a racemeeting held on Empire Day, with Bisalla up, beat a field of Emir's horsemen by three lengths.

One little peep behind the scenes, before I forget it. A certain high official was on tour, and I wired to him to know if he proposed to meet a certain higher official on his arrival at Lokoja. "Not in these," came the reply. The chief clerk was much perplexed, and suggested that we should have it repeated. I told him that it simply meant "no," and that he should so type it on the records. But the strict fidelity to the letter of red tape in which these folk rejoice made him demur at such a departure from regular procedure. Then timidly, and all unconscious of any witticism: "Perhaps it would be better, sir, to type: 'Not likely'?" (!)

Francis had taken over the province in June, and we used to have some pretty little shoots with the duck and snipe at the Old Barracksnotwithstanding the nervousness with which Francis regarded Thornton's menacing hammergun. Unfortunately he went on leave in three or four months. At his farewell dinner, a very merry banquet, one lady created a mild sensation by saying, as she took her departure at 1.30 a.m. : "Mr. Francis, I do hope you will forgive us for rushing off like this!"

Then, with October, came Percy O. Holt to 
reign in the stead of Carmichael. Legion again are the tales told by and of him from the Cross Rivers to Yola. Bon viveur, raconteur, and puller of legs, there was no walk in life he could not have adapted himself to, had he so chosen, from billiard saloon to Regius professorship of literature.

For quiet humour I always liked his naïve little tale of his twin brother who was wounded in South Africa. At the outbreak of that war the brothers felt that they must "do their bit," but as one of them must look after the business, they decided to toss for who should go. "So we tossed for it," said Percy, "and I wonlost, I mean!" Percy had himself gone forth to the Great War in the Cameroons; and the vultures of those parts relate that, during one particularly strenuous bush-drill, Corporal Holt cried aloud: "You may court-martial me-you may shoot me-but I cannot move another yard!" and laid him down to die 'neath a spreading tamarind-tree.

Some few days afterwards QuartermasterSergeant P. Holt was urging a decrepit, weary, and sagging horse barrack-wards, when he encountered another warrior also mounted. The war was still young, and Percy-not yet versed in the subtle distinctions of rank which differentiate between the great and the smallto be on the safe side fell to saluting heavily.

"All right, sonny, you can cut all that out: I'm the farrier-sergeant!" was the answer to his uncalled-for homage.

"Oh! Are you?" said Percy, "then just 
get off and tell me what's wrong with this hairtrunk of mine!"

His repartee was inimitable. His retort to a lady who had heavily overcalled her hand at bridge, and then said:

"Well, what would you have called, Mr. Holt ?" is worthy of record.

"I should have called a policeman!" was the sorrowful rejoinder, as 600 of the best was chalked above the line.

Colin Walker once got level with him. Holt had complained that his messengers were kept waiting at the Provincial Office.

"I shall give them chop-money in future," he wrote, "they get so hungry."

"Noted," replied young Colin. "As regards my own messenger, who has been waiting for coffee for two days at your store, I have now sent him to Lokoja. ${ }^{1}$ It will be quicker."

Of a morning, if he did not feel in the best of health, he would say with a groan: "You behold in me the ruins of a once handsome man!" His matutinal interviews with his cook on the subject of the price of mutton, and his homily on Christianity when that menial defended himself from the allegation of charging one-tenth of a penny too much by saying: "Master, I be Chlistian (sic)!" were as entertaining as they were heterodox. As for his customers, he took each on his merits. "A remittance will surprise," was once the footnote with which he shamed a "non-drop," as he used to call a reluctant payer into settling.

${ }^{1}$ A round journey of a fortnight. 
Christmas dinner 1916 was a humorous affair in more ways than one. Fverybody contributed something or other-except one officer, who put at our disposal instead his nautical vocabulary, and periodically asked us with a sort of maritime breeziness whether "our glasses were charged, gentlemen ?" "Yes, but not charged for," muttered the dour Carmichael, who had put up mo : of the glassware himself.

A slight panic was created when, on someone unhappily whispering that he thought we were a bottle of port short, our redoubtable Commissioner of Police, Major Ellis, instantly summoned the sergeant-major and threatened to arrest the entire domestic staff.

Then a Greek merchant rose and gave us a dissertation on the situation in the Balkanshe pronounced it "Bălkans," as in "fal-da-ral " -drank damnation to his sovereign, King "Tino," and finally sang the Greek national anthem from beginning to end.

By this time Percy, wearied with the exertions of carving and his special Yule-tide conversational efforts, decided to retire outside for a breath of fresh air and forty winks. Removing from a folding-chair an effigy I had made of the Emperor Wilhelm with a view to burning it later, he settled himself therein, and relapsed into a well-earned slumber.

Meanwhile, the rest of us were endeavouring to play "Subject and Object," with indifferent results, for Bobbie would not, and Dr. McKinney could not, grasp the principles of this instructive 
game. Suddenly it occurred to me that we had not yet "burned the Kaiser," and we all adjourned outside. Fuel was collected and piled round the chair in which the effigy reclined. It was a dark cold night, and the bonfire was all that was lacking to make things like an old-time Christmas. I struck a match, approached the Emperor, and-just failed to cremate not His Germanic Majesty, but a very august if somnolent British subject in the shape of P. O. Holt !

Ten days later the Annetts and myself were stowed in the boat-train homeward, when, as the whistle blew, we received a wire from Elder Dempster to the effect that our passage was cancelled, as the Tarquah was full up. So "we all walked out again!" I explained to Wood that I had finished, stored, or disposed of all my chop, but I added cheerily that I should have to make a picnic of the ensuing fortnight.

"Which means, I suppose," said Wood gloomily, "that I shall have to give you all your meals." "Certainly not!" I replied, "come and breakfast with me to-morrow!"

Breakfast-time and Wood arrived, and the boys proceeded to enumerate, one after the other, things I had not got. "Tea ya karre!" "Babu sugar!" "Kwoi ba!" etc. But when they announced that the cook, whom it will be remembered $I$ had handed over to Wood (at increased wages) for the period of my leave, was cooking breakfast in his new master's compound, the latter's indignation knew no bounds. But I followed him to his bungalow, and there enjoyed 


\section{YOLA AND ILORIN}

a nice little meal with him, cooked by my own cook, free of expense!

At length we sailed by the Abosso ${ }^{1}$ (Captain Toft), and arrived at Liverpool on February 15th -my pockets bulging with threepenny-bits won from our table-mates, Crocombe, Vereker, and Charlie Ashton, at that fierce game of chance, "Newmarket."

1 Torpedoed May 1917. 


\section{CHAPTER XII}

\section{ILORIN}

My Odyssey draws to a close. There was a pessimistic atmosphere on the outward voyage of the Abinsi (Captain Wright). While boys of twenty-four and twenty-five at home were majors and colonels, and seconded survey and railway folk had blossomed into major-generals, promotion in this country, in spite of the increased responsibilities thrown on a depleted staff, was completely stagnant. So also was your salary, unless you managed to pass the Lower Standard Hausa, which, be your lot cast among the Bornu Beri-beri, or the pagans of Bassa, you were expected to do, or forfeit your increment-a sum of money, by the way, which exactly represented the difference between a "good" and a "plain" cook! Then, having "got the wind up," as Tennyson hath it, and passed the Higher, you were transferred to Benin, where needless to say Hausa is as intelligible to the Benin as it is to the Beri-beri, or Bassa.

It is instructive to note in this connection that, as regards Bornu, a reward of $£ 200$ having been recklessly offered to the first official mastering the Kanuri language, and subsequently with some anxiety reduced to $£ 150$, the consequences of 
this ruinous promise were finally avoided altogether. For the philological discovery was made (it is believed. by Mr. H. G. Wells when piecing together his data on the Pleistocene dawn) that Kanuri was not the lingua franca of that province, but Shuwa Arabic! Heureka! echoed the Government gratefully; and Shuwa Arabic was forthwith gazetted as the compulsory language of Bornu. A pleasing ruro-academic picture, the Kanuri peasantry swotting for their Lower Standard Shuwa Arabic : though it must be difficult to get tutors during the dry season, when the venerable Shuwa professor has shifted his cattle-dung University to Cameroon pastures, free from fly and, incidentally, the embarrassments of British taxation.

Dix allowed me to share the Presence in his cabine de luxe during the "torpedo season"; and I then retired to my own in the bowels of the ship. "Pansy," my new spaniel, was tethered to the six-inch gun aft, and it was in some consternation that I hastened to release her and take her forward, when battle-practice was announced to be imminent. I need not have panic-ed: the first two shells made no noise!

I found myself posted to Ilorin again, with Elphinstone now in charge, and once more I took over the Division.

"Pansy" took to the gun like a duck to water. For partridges and guinea-fowl in the long grass, and snipe and duck in the swamps, she was invaluable. A little incident occurred at Offa one week-end which might have been disastrous. 
I was out with a gun, and heard a faint yapping behind me. The sight of a hare always threw "Pansy" into a paroxysm of excitement, and I thought she must have put one up then, so did not concern myself much. But as I went on the yapping became more insistent, though fainter and fainter. I sent the boy back, and shortly after heard him cry: "Ta fadi rijiya!" ("She has fallen down a well!"). I hurried back, and there she was swimming round and round, and splashing with her great fat paws. Making a precarious sort of human ladder with Atuma, I managed to rescue her. That same week-endhow she did it I do not know-she caught a hare! Much panting, squeaking, and mutual embarrassment on the part of captor and captive! She had hare for lunch and dinner. Occurrences such as these are trivial enough, but they assume some magnitude in the dull and solitary evenings in Nigeria.

These little trips to Offa, and the badinage with mine host Nell, were always great fun: and, when I speak in my prayers of "forgiving those that trespass against us," I try hard to include him in the general pardon; though I feel that nothing short of a special service of intercession can wipe out that gun affair-but he always disarms me when we meet with the Nelson Keys smile that turneth away wrath, a handful of cartridges, and a dozen cold soda!

Some two months of my time were devoted continuously to the not uninteresting analysis of the family or fiefhold tenure connecting the various 
"districts" of Ilorin to the Court. It is the only way to preserve native custom, and avoid trampling on the corns of tradition. The white man does so love to "join up" villages and areas which have no historical or family connection, simply because it makes things superficially easier for himself, and looks pretty on the map. "Centralizing" he calls it; whereas, if he only knew it, he is probably tearing an infant, so to speak, from its own mother's breast, and joining it up with a milkless foster-mother, or even a male! Three-quarters of the intrigue, extortion, and general maladministration will be found to be due to some plausible white man's nominee being put in charge of a "coadunate" 1 district, while the family, who by custom and history should be ruling in his place either create a rival faction in the district, or sit in the headquarter town, like Achilles, brooding and hatching mischief in their tents. The folk of the district, moreover, will not suffer strangers gladly, but will flock to the town and lay their troubles before their natural family head, or "baba kekere." It was during my travels on this particular mission that I attempted, with the rains of a record year in full swing, to cross the flooded Oyun River near Oloru in my bath. I was upset by my over-anxious bearers, and nearly drowned. The Emir paid me a special visit of condolence on my return!

About September Colin Walker was "combed

1 A term much favoured in Political Memoranda: but as to the meaning of which nobody that I have met has any fixed idea. 
out," and Elphinstone and I had to take turns to tour and run the Office, Station, Cash, Food Control, and Police. They were strenuous days, but I was getting to know both the locale and the locals; and a lot can be achieved where there is that, alas! rare flower, continuity.

Percy Holt was still going strong; though, as time wore on, his threats to "go home next month" became more insistent. The local Hercules, one Wimpole, christened by the facetious Twiss, and popularly known as "Michelin," or the "Round Man," used to afford us good entertainment, not unmixed with anxiety when he showed signs of getting roused. "Wait till $I$ get hold of him !" he would say, "I'll tick him off! I'll__" "Oh, Wimpole! Be merciful! Don't hit him, promise us not to hit him!" would be the fervent chorus. For one blow from the Round Man, as he has often told us himself, would be the last. In fact we seemed to spend most of our time restraining this Titan from some awful homicide. Yet when he had temporarily sheathed his biceps, and placed his muscles in repose, and put up one of his priceless palm-oil chops, no more perfect or peaceable host existed. He was, I believe, champion weight-lifter of Scotland. But Percy would ask irrelevant questions as to whether the weight was Avoirdupois or Troy, and whether a long tumbler or the bitters bottle were the greater strain. Mountaineering was, he assured us, his favourite recreation. "Put me among the mountains!" he would murmur devotedly. The nearest we could get to carrying out this 
request was to conduct him up the almost imperceptible gradient from John Walkden's to the Tennis Club-an effort recalling rather the Labours of Hercules, or, as George Anderson (I am coming to him) put it, H.M.S. Vindictive cement-laden, and staggering to her last resting-place at the bottom of Ostend Harbour.

The before-mentioned Triss added his quota to the gaiety of nations with his sleight of hand, his mandolin, and his drawing-room stories. His perfect French added an air of distinction to the station. It will take me some time to get over a week-end I spent with Twiss at Bode Sadu. His clerk there possessed an old gramophone, and a record, amongst others, of "Living the Life in the West." With a sly look at me, Twiss rubbed in to the clerk what a fine record this was. Now, a native knows no half-way house. If a thing is good, it is good, and you cannnot have too much of it. If you tell your cook the soup is good, he will give it to you for breakfast, tea, lunch, and dinner, till you scream for mercy. So the clerk. He played that drivelling tune ceaselessly from 7 p.m. till 10.30 ! And then came and asked for a "dash." He did not get a dash-but something not unlike it.

In December, to my great surprise and pleasure, but not so much to his, $\mathrm{Pa}$ Benton ${ }^{1}$ was posted to Ilorin-his return to Bornu being ruled out of court by the medical authorities. Though it meant his taking my pet Division from me, his company and good fellowship more than made

1 Died October 31, 1918 (vide Appendix C). 
up for this bereavement, and I have seldom spent a more congenial eight months than those from January to September which followed.

Having been in Bornu together and come into contact with the chicaneries of Shehuri Court life, we found it illuminating to compare thereto the affaires diplomatiques of the Ilorin Palace: and the conclusion was that, had the chancelleries of Ilorin been pitted against those of Bornu, the former would not have come off second-best. The Emir himself, 1 like the Shehu, was an amiable, well-disposed monarch-on the whole without vice -but his Court was honeycombed with the dens of the unofficial "judge," the office-procurer, and other unpaid body-snatchers of that type. These, as in Bornu, were gradually got rid of ; but, as also in Bornu, were inevitably succeeded by understudies willing and waiting, "ungulu"-like, to step instantly into their shoes.

Almost coincidently with $\mathrm{Pa}$ 's arrival the mysterious loss of the Umjeni outward bound became accepted as a tragic fact. She was apparently last spoken by the Salanga in a terrible gale, and is assumed to have foundered with all on board, including poor Tamsie (vide Chapter VI and Appendix B).

$\mathrm{Pa}$, of course, at once got to work on a polo ground, and the whole of the Yola Polo Club paraphernalia was taken over with a view to starting the game in the dry season. At the moment of writing the Ilorin staff is more attenuated than ever, while that nauseous pesti-

1 Died November 1919. 
lence, known as Spanish influenza, is devastating whole cities and provinces, impartial in its deadly attentions to black and white. So that the destiny of Ilorin polo is rather on the knees of the gods at present.

In March I did a re-assessment of Malete District, but, though my peregrinations took me through the parts about Old Oyo, and I was buried for some three hot days without any fresh food in the heart of the Kontagora forest, I saw nothing in the flesh-only innumerable tracks, some of them yet warm, of buffalo, elephant, and roan. The same old disheartening storythe shadow, but not the substance.

During my periodical visits to Jebba I still maintained the most desperate efforts to secure my first bush-cow. That excellent host Goodall (alas! the latest victim of the plague ${ }^{1}$ ) used to lend me his barge, and horrible were the riverain haunts $I$ used to tour therein in my relentless quest. Equally relentless were the tsetse, mosquito, and sandfly in their own line of pursuit -human blood. Once, after retiring to bed fatigued and dispirited from a fruitless hunt in long, miasmic speargrass, I called Atuma to bring my watch, as I was anxious to push off betimes from the island where we were camped to the opposite bank of the Niger. He brought my watch, struck a light, and, in a second, my mosquito-net was a mass of flames! I sprang from my bed; and wandered about from $\mathbf{3}$ a.m. till dawn eaten alive. 
On my return to Ilorin I received a letter from Biscoe, who was touring the Nupe States of Lafiagi and Pategi, triumphantly informing me that he had shot his first bush-cow. This was too much for me. In a fit of jealousy I wired Goodall to have the barge ready, and sped to Jebba. Thence to the usual nightmare on Fangam Island, and up at 4.30 .

At 5.45 I had landed for the $n$th time on the west bank, and then-O frabjous day !-at about 6.20, calmly browsing and flicking the flies off with their tails, there leisurely strolled from behind a patch of scrub some fifteen buffalo, only eighty yards away on my left flank. And the hunterman proceeded to say "Gashi!" and handed me my-shot-gun! If a look could murder a man, mine would have killed him. ${ }^{1}$ Fortunately his imbecility did not attract the attention of the quarry; and I grabbed the $\mathbf{3 7 5}$ from him, and raised it to my shoulder. I had singled out what appeared to be the big bull and father of the herd, but a second patch of scrub temporarily obscured him, and then the brawny neck protruded again. I let loose at it, and the welcome plosh ! so familiar to anyone who has done much shooting, as opposed to the empty reverberation of the misdirected bullet, told me that I had struck home. There was a stampede, some dozen cattle dashed past me to the right, and momentarily I lost sight of the bull I had hit, for it did not fall.

Sheering off from her mates, an angry cow, with lowered head and calf trotting at her flank,

1 He did, in fact, die shortly after. 
came boring along straight for where I stood. I put an erratic bullet into her-evidently in some non-vital spot, as it proved afterwards-which deflected her, and sent her grunting headlong after the rest. Simultaneously bloody and staggering-the typical neckshot stagger-about twenty-five yards in front of me appeared the bull. Another shot, through the heart, laid him low. He proved to be a massive brute, in the pink of fatness and condition, but an old warrior with horns warped and worn with fighting. They did not measure more than twenty-one inches, while the hide weighed $104 \mathrm{lb}$. wet, after the neck and mask, and of course the feet, had been severed.

When starting for Jebba in mad haste, Percy Holt had shouted after me: "And I bet you $£ 50$ to $£ 1$ you don't get one!" Unhappily he says I did not take him!

Anybody wishing to probe the real "back of beyond" should have accompanied me one day in early June into a certain morass on the west bank of the Niger, not two hundred miles from Boussa, where Mungo Park met his death. Half swimming, half staggering into this delectable swamp, I suddenly put up a herd of what I cannot estimate at less than fifty buffalo, who sprang from their various postures, and went crashing off. Catching sight of a small brown patch as it vanished, I let fling at it. Stealthily advancing to the spot, I found a pool of blood. Now following a wounded buffalo in the blind grass is not to be recommended; and it was with the utmost caution, and with 
nerves continually on the stretch, that I pursued the blood tracks for some six weary hours in awful country. She was apparently a female, for we kept coming upon patches where she had endeavoured to lie down, but had been boosted up and on again by her discrete, but unsympathetic calf. At least so the hunterman read the signs. Though the chase was resumed next day, I never landed her; so presume the wound was not fatal. In any case I should have been very lucky to have secured her with so haphazard a shot.

Two local buffalo anecdotes may be of interest. The first I can vouch for: the second is Biscoe's contribution.

Nine miles south-west of Jebba a hunterman wounded a bush-cow, and advanced to finish it off. The brute turned and went for him : whereupon he hurled himself down and shammed death. The bush-cow stood astride him, biffed him first with fore and then with hind feet, urinated upon him, and then disdainfully left him for dead. At nightfall a bleeding mass of human ribbons tottered into the village-but still lives to tell the tale.

Biscoe's sportsman announced to his friends in Offa that he was off to kill a bush-cow. He failed to re-appear. His friend went forth to look for him, and returned later carrying a small basket. "Didn't you find him?" asked the anxious villagers. "Yes," replied the friend. "Well, where is he?" they cried. "In here!" he retorted significantly, emptying from his basket a few small gobbets of flesh. The bush-cow had done its job more thoroughly in this case. 
On subsequent visits to Jebba I got another waterbuck, and at last! a bush-buck; so that I shall always retain kindly recollections of Jebba, death-trap though it was. It was once Headquarters: and the cemeteries there tell their own tale. According to one date apparently three patients and the doctor were buried on the same day! I once paid a call on an engine-driver living at Jebba North. "Care to have a walk round ?" he said: and we did-round the graveyard upon which his back door opened! I sympathize with any driver for getting depressed on that grim spot, in the days before they were shifted to the Hill.

My duties used to take me constantly up and down the line; and it was during one of these tours to Offa that Stephens, the M.O., impressed upon me the rampant manner in which small-pox was spreading in the town, and the impossibility of coping with it until the "worship" of the fetish (with which he had come in contact in the Southern Provinces) had been taken in hand, and the juju men brought to book. I went into the matter exhaustively, and found it had not been exaggerated. The ritual was founded entirely on blackmail. The modus operandi was for the "priest," or his client, to threaten : "If you do, or do not, so and so, small-pox will catch you!" Then if the threat did not produce the desired effect, the principal, or agent, would work the "juju," generally by jostling the victim in tine market, or in a crowd, where he would escape identification, and sprinkling him at the same 
time with the virus-generally particles of dust, or other infected matter collected from the body of some wretch already stricken with the malady. The sample I obtained was in the nature of pepper, or snuff.

So fiercely had the terror of this evil thing gripped the morale of the community in its tentacles that the most inoffensive individual would pay a heavy contribution to be enrolled as a member of the society-hoodwinked by the priesthood into the delusion that he would thus secure immunity from the disease. Further blackmail had of course to be paid periodically for the privilege of retaining that membership. Though it was transparent to me that the whole town would sell their souls to be quit of this sinister cult, they were too terrified of possible consequences to try to free themselves. One old man, pitted almost beyond recognition, told me that he had once disregarded a threat, and concealed himself in an outlying hamlet. His seven children were all fatally attacked at intervals, always preceded by a warning or symbol of some sort, and died one after the other.

At length I got certain men to give information, on the condition that $I$ would make a clean and impartial sweep of the priesthood, and leave no offender at large to keep the worship alive. Backed by the Oloffa, who had hitherto out of sheer fear supported the society, but was at heart as keen as everybody else to have the unclean shadow removed from his town, I committed and sentenced to terms of imprisonment some dozen 


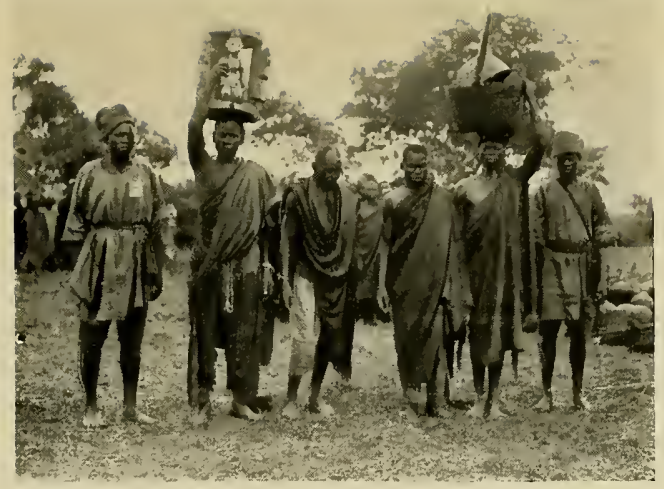

SMALL POX JUJU WOREHIPPERS UNDER ARREST.

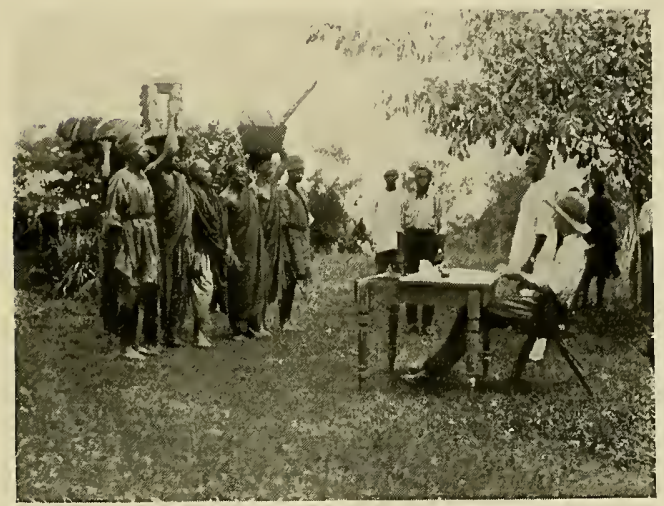

TRIAL OF THE DELINQUENTS.

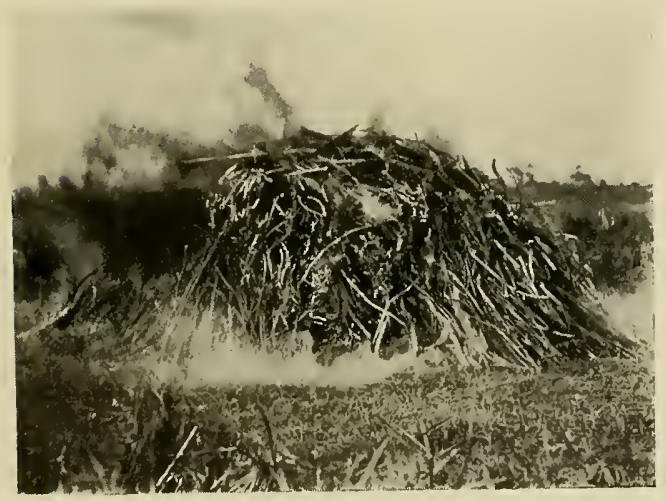

PUBLIC DESTRUCTION BY FIRE OF SALLL-POX FETISIIES. 

ringleaders, severely cautioned more than $\mathbf{2 5 0}$ worshippers (more sinned against than sinning), and publicly set fire to three hundred odd idols, charms, etc.

Once it became popular knowledge that the "game was up," and the impotence of the juju as against the White man exposed, people flocked to the scene, and of their own free will hurled their noisome symbols into the conflagration. Volunteers actually came in from neighbouring villages next day, and a supplementary bonfire had to be kindled as large as the first! I shall be indeed surprised if there is ever a recrudescence of this horror. The pontifices maximi of the Small-pox Deity are meanwhile much more happily employed on the cleaning of latrines, and other convict labour of a humane and sanitary nature!

From now onwards I had the supervision of the Police added to my other duties. Wonderfully efficient and well-disciplined men, considering they are nobody's children (their officers being perpetually below strength), and at the mercy of any amateur who comes along. I was swearingin a recruit one day, and he had just declared his fealty to "King George, his heirs, and successors," when the voice of the office orderly chipped in: "—and the sergeant-major!" (!)

Another little conversation I overheard about the same period between a sentry, who wished to impress me with his alertness, and an unsophisticated passer-by will appeal to those who understand Hausa.

"Halt! Who goes there?" 
"Na-am ?"

"Halt! Who goes there?"

"Na-am?"

"Wane irin mutum na che Halt! Who goes there? ya. che Na-am ? Pass fren'-dandurin' waka! wofi !"

Translation would ruin the piquancy of these exchanges !

The Police were a sore trial to S. W. Walker, who lived just over the office. "It is not so much the changing of guards and clatter of rifles at 5 a.m. I mind," he said, " as the uproarious laughter (compulsory) of the rest of the force at the sergeant-major's jokes."

Little remains to be told; save that, in August, George Anderson (rudely known as "Tin Eye") relieved Elphinstone. A wonderfully dry gentleman, distinctly and pleasantly reminiscent of Hewby. I feel confident that, if one had sent him a chit to the effect that his house was in flames, or that at $\mathbf{1 0 . 3 0}$ precisely "date" the Last Trump would sound, he would have simply written "G. A." across it. Whatever their intrinsic significance, somehow those initials seemed to convey implicitly : Go away!

One of his first official acts was characteristic. He returned the monthly Duty Pay I had sent across to him with a polite request that $I$ would deduct all Government dues, such as Conservancy, Bicycle, Arms, Warehouse, etc., fees, and let him have the balance, if any, in notes! One of his last memos to me ere I left ran as follows: "I am told you have got some of my turkeys 

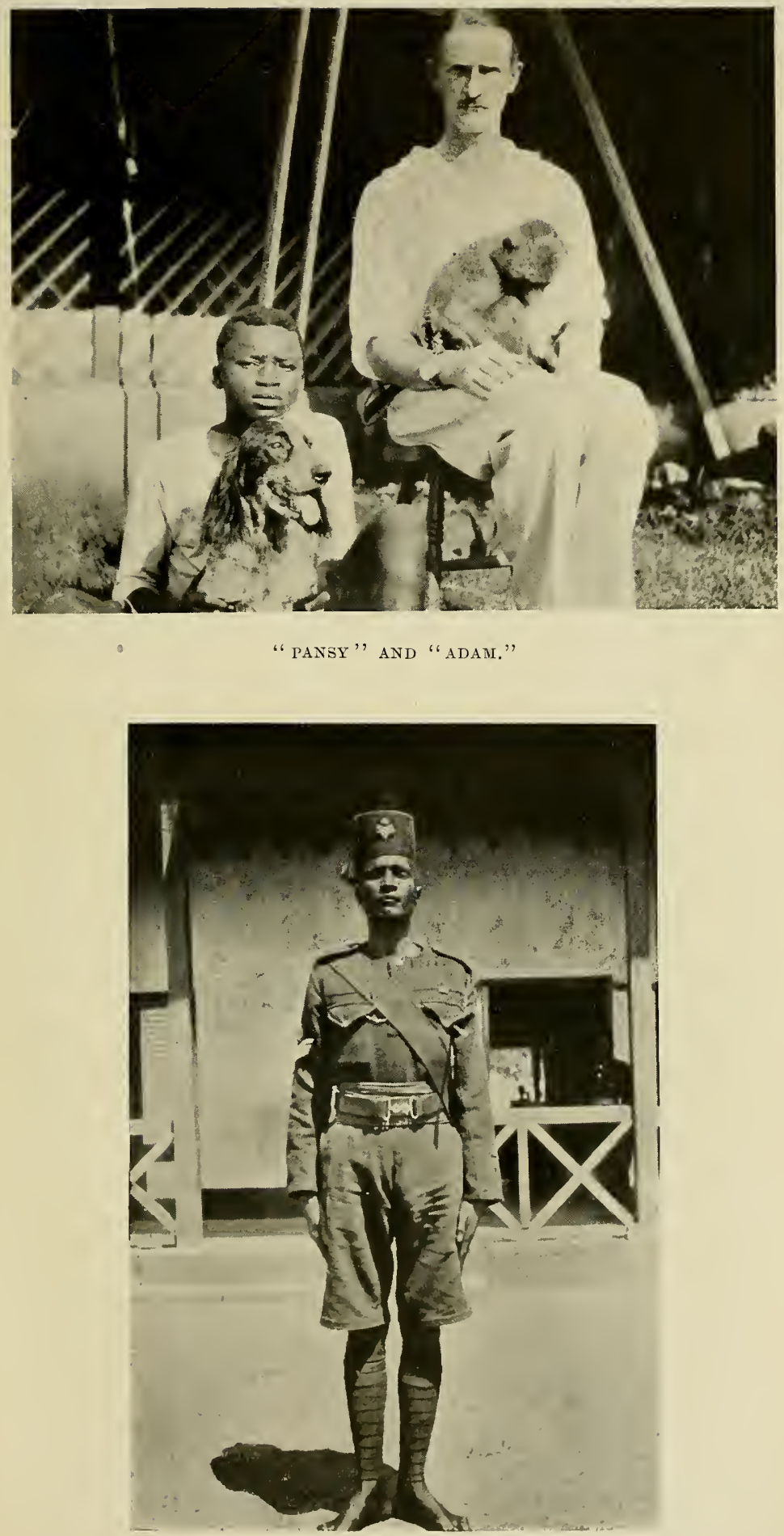

in your compound. Also that you have beaten my cook.-G. A.

"P.S.-I am glad of the latter."

Many of his obiter dicta are worthy of, but not suitable for, reproduction here. $\mathrm{He}$ was once dragged out of bed at midnight, during a visit to Offa, to investigate a burglary at the local post office. He threw the postmaster, a horribly nervous man, quite off his balance by addressing Stephens, whom he had taken with him as a witness, as "my dear Watson." The post-office drawer had been incidentally set fire to, and the postmaster tentatively suggested that kerosene had been first pumped in through the keyhole. "And then the cash pumped out?" observed Tin Eye, leaving the last state of that postmaster worse than the first.

He would get a little weary of the nightly discussion on the tennis court as to whose turn it was for a game, and who should play with whom. Whereas Percy Holt would bluntly remark: "We're not keeping you up, are we?" Anderson would say much more politely: "Please choose your own partner, and side of the court, and take the service-no, I prefer the sun in my eyes!"

So life went on son petit train train until I received orders to transfer to the Southern Provinces-whether for better or worse, richer or poorer, for honour, glory, and promotion, or on the analogy of the Chiltern Hundreds, flung at the discarded minister, who was I to foreshadow ! There-with the commencement of a new eramy narrative shall end. 
And now a parting word in justice to the Service to which $I$ have the honour to belong. The Great Public have familiarized themselves with the bread, tea, and sugar queue-even the "literary queue" has been boomed by the Morning Post. But there is another queue, whose dimensions are only known to those of whom it is composed.

I refer to the testudo of Colonial Officials who, at any rate during the first three years of the war, battered at the Holy of Holies of Messrs. Walter Long and Bonar Law, begging, cajoling, even threatening for transfer from Civil to Military service. It goes without saying that this wholesale abandonment of colonial affairs to take care of themselves could not be entertained, if we meant to keep a grip of our possessions-though an extensive combing out did take place, saddling those who were left with the added burden of those who were taken. But I merely mention these facts to show that it was not for lack of trying that the colonial civil servant was still in Africa instead of in France.

But there is another aspect of life in the Outposts which does not easily convey itself to the unreceptive mind of those at home, owing to the entire absence of limelight to show it up. And that is the continuous campaigning conditions under which the average Political Officer in the outstation lives in normal times-quite apart from the trebled responsibility and strain imposed by the exigencies of war. One day losing his way, another his carriers, another his loads; sleeping as best he may under some friendly tree, with 


\section{ILORIN}

the earth for his bed, and the moon for his candle; going without food or water for twenty-four hours at a stretch; swimming rapids at imminent risk during the wet season, and suffering a hundred discomforts of dust, heat, and insects during the dry; working and travelling at high pressure with fever upon him: above all, the Solitude, twin-sister of Sickness, mental and physical, days away from a white man, let alone a doctor, and relieved only by the endless chatter of the nigger -all these are in the order of the day, Peace or War. Most of them simple occurrences, which he has learnt to grin and bear, if indeed he notices them at all, for he is so used to them. No honourable mention for all these things: no brevets : no investitures. The Navy has fairly earned the sobriquet of the Silent Service: about service in the Dark Continent there is a Dumbness stronger than speech. Its slaves do not get, and do not ask for limelight: but let them in justice be remembered when the tale of the Great War is told. 



\section{APPENDIX A}

(Reproduced by the courtesy of the Editor of Blackwood's Magazine.)

\section{SULI YOLA}

Dick Turpin, Jack Sheppard, Claude Duval, and other exponents of the fine art of crime, have been immortalized in prose and verse. Suli Yola is, as far as I know, unsung. Here is his story -or that part of it at any rate with which $\mathbb{I}$ personally came in contact.

I first met him undergoing a sentence of forty days' imprisonment for adultery. The judge who tried him was a fine shikari, and a first-class tennis player, but-needless to explain-no lawyer. The conviction was of course quashed, but not beforc he had served his time.

The next occasion on which I met him was at the sports of "A" Company of the Nigerian Regiment, in which he had re-enlisted under a false name, having been discharged from " $\mathrm{E}$ " Company as a leper. He only participated in two contests: one the wrestling, in which he threw every antagonist at the first grip; the other a Marathon race from the town-wall to the station, in which he beat his opponents by about half the distance.

A fortnight later, during the night, a terrific 
tornado burst over the station, completely wrecking (as it appeared) the post-office doors and windows. But when the contents of the postal boxes, including $£ 25$ in gold, were found to have vanished, it became reasonable to suppose that the human element had also played its part. Exhaustive investigations and many arrests were made, but without result, and the affair was gradually forgotten. Then one Private Isa Bauchi brought to my office a claim for $£ 5$ against Suli Yola. I asked him for details. He became reticent. I pressed him, at the same time remarking that it was a large amount considering both claimant and defendant were drawing less than $£ 2$ a month. Isa then anathematized Suli Yola, and said the amount was really $£ 10$-being his share of the proceeds of the "Giddan Wire Palaver" (literally House of the Wire, i.e. telegraph office). Suli was immediately discharged by the officer in command of "A" Company as inefficient, and it was arranged to watch his movements and have him arrested as a civilian. For this purpose three police were detailed. Their efforts to be tactful and appear unconcerned were clumsy and ridiculous to a degree. Suli, who had sized up the situation from the moment he received his discharge, dogged them as they walked about the market pretending to buy merchandise, and made faces at them, saying, "Here I am; don't be afraid ; arrest me!" Fearfully and reverently-it transpired later that the world in general was terrified of Suli, who was believed to possess evil spirits or Ju-ju-they 
did so, and brought their captive back to the Residency.

"Charge him with everything that has ever happened since he has been here," said the Resident, commonly known as the General.

I give to the best of my memory the interview which took place between Suli Yola and myself at the preliminary investigation, which corresponds roughly to our police-court proceedings.

"Your name?"

"Dusi."

"Why are you known as Suli Yola?"

"That was my name when I was in Yola Province. I was 'Tom' in Kano Province, and 'Brahm' in Bornu. It is not convenient to have one name."

"You are charged with breaking into the Wire House, etc. You are charged with stealing two bottles of the captain's whisky on the 17th August; with stealing a loin-cloth and a bottle of Worcester sauce from the Resident's cook's mate on the previous Saturday; with selling three telegraph-poles and iron rods to Audu the blacksmith; with stealing, two nights ago, the doctor's mosquito-net and sparklet bottle_-"

"Babu-ban shiga wanan ba" (No! I had nothing to do with that).

"Why not?"

"Because I was employed that night by the sergeant-major on the road to the town to watch the interpreter, and see if he was courting one of his, the sergeant-major's, wives." 
"You were out of barracks then?"

"I am always out of barracks. Anyone who wants to steal anything comes to me and asks me to do it. They are too clumsy themselves. I frequently steal for the sergeant-major. He got me reduced once for refusing. $\mathrm{He}$ and $\mathrm{I}$ and Isa Bauchi were all in the post-office show. I was naked; I had taken Ju-ju, and oiled myself all over. We had no lights, but found our way about by the continual lightning. I slid in, and handed the money out to the sergeant-major. $\mathrm{He}$ took it, and said he would bury it at the $\mathbf{3 0 0}$ range. I never got a 'toro' (threepence) out of it. I will kill him when convenient. I am not afraid; I could easily have run away when I was discharged, but to see the Police pretending they had not come to arrest me was 'maganan daria' (a matter for laughter)."

In a nutshell, Suli, alias Dusi, alias Tom, alias Brahm, pleaded guilty to all the charges except the mosquito-net affair, from participation in which he was unavoidably detained on business. As a result, Suli, the sergeant-major, and Isa were brought up for trial in the provincial courthouse.

At this juncture the gaoler came up to the General and said he could not be responsible for the safe custody of Suli, as every night he "turned into a mouse and got out through the bars."

This, strangely enough, was corroborated by the prisoners sharing his cell.

"Personally," remarked the chief clerk, a 
highly educated man, whose brother had been at Oxford, and is now a barrister in Lagos, "I do not believe it" (!)

The trial was in many respects the most dramatic I ever witnessed. The "alkali," or native judge, was present at his own request, and the court was packed with inquisitive natives agog to see the "Sarikin Ju-ju." Suli stood, the picture of indifference and innocence, between his two warders, until the time arrived to give his evidence, when courteously waving them back, he quietly slipped off his handcuffs, placed them on a table, and proceeded to demonstrate the part that he, Isa, and the sergeant-major had played in the robbery. On completing his evidence, he stepped back, replaced his manacles, and resumed his attitude of innocence.

"Damn it all!" whispered the General to me. "He only wears them to oblige us!"

To cut a long story short, the sergeant-major was acquitted, and Isa and Suli both found guilty. Before passing sentence, however, the General, recalling the mysterious disappearance of a large sum of money from the fort in Bornu when he was last in that province, wired to the Resident for the names of the guard on duty on that occasion. The reply came back-

"Momodu, Kachella, and BraHm" (!)

Isa received two, and Suli three years' imprisonment.

Profiting by the experience of the handcuffs, the General ordered the gaoler not to allow Suli out on prison labour until the native blacksmith 
had forged and soldered a pair of stout leg-irons on to his ankles, so that there could be no "springing" of the locks, such as might occur in the case of those supplied by Government.

Overnight, as we subsequently learned, Suli addressed his fellow-captives thus: "I had hoped to stay a few days among you, and to arrange for the cutting of the sergeant-major's throat. They have determined, however, I hear, to bind me with native leg-irons. I find it advisable, therefore, to leave you to-morrow some time, but please inform the sergeant-major that I shall certainly cut his throat eventually."

At eight o'clock next morning I was sitting in the office when two shots rang out. My glance met the General's.

"Suli Yola, for a thousand!" he exclaimed, as an excited warder rushed in to tell us that Suli had asked leave to fall out, and had then melted, leaving his leg-irons and his knickers on the ground.

"Take him out and give him 'bulala' (whip) till he can talk sense, and tell us what really happened," said the General.

This was done-whereupon the interpreter took up the story.

"After he had melted___"

"You'll get 'bulala' next if you use that word again," said the General.

I quote this conversation to illustrate the thorough belief shared by interpreters, warders, and clerks alike in Suli's powers of Ju-ju. Not the least humorous aspect of the episode was 
the sight of the other prisoners, some twenty in number, marching back unescorted, the warders having gone off in a half-hearted pursuit, waving Suli's knickers and shouting: "He has escaped! The Bastard! His fashion is evil: he has done a bad thing."

Meanwhile the guinea-corn field into which Suli had "melted" was surrounded and watched night and day, and the district scoured by "A " Company and mounted messengers, but to no avail; and the next we heard of him, some three months afterwards, was that he had met the commanding officer of his old " $\mathbf{E}$ " Company (who was entirely ignorant of his misdeeds) on the Benue River, greeted him affectionately, and received a "dash" of five shillings from him for " auld lang syne."

Aware though he was that he was still wanted, and liable to be shot at sight, he shamelessly reappeared in barracks and openly marched off with a police-constable's wife, whom he alleged to have belonged to him. For witnessing this adventure, but being too frightened of $\mathrm{Ju}$-ju to interfere, the police-sergeant was degraded.

Three months had barely elapsed before a colour-sergeant was relieved of some fifty pounds in cash during absence from his bungalow at Ibi. The thief was never found, but it is a significant fact that Suli Yola was a prominent frequenter of the Ibi market at the time, and blossomed out into most expensive habiliments during the following months.

Then the Ibi post office received much the 
same treatment as the famous one at Bauchi. The guilt was brought home to Suli Yola, now styling himself Mustapha. On his way to the gaol he informed his escort that his incarceration was a mere formality to please the white man; that he would become a rabbit during the night and be sleeping in the bush by daylight. At six o'clock next morning a hole was found in the gaol floor leading through the back wall. The hue-and-cry was raised, and news arrived by a messenger that Suli was at a village, some fifteen miles away, demanding the hand of the daughter of a neighbouring chief, who, seeing that his prospective son-in-law brought no other marriage gifts than a portion of leg-irons clinging to his person, detained him in parley, and sent information to the Resident. Suli was surrounded and captured.

I believe, but am not sure, that he again escaped and was again recaptured. However this may be, when last $I$ heard of him he was confined in a long-sentence prison with a pained expression on his face, and on his waist and thighs a solid rock, some one and a half times his own weight, which encumbrance explains his explanation to the world at large that his "Ju-ju done finish."

LANGA LANGA. 


\section{APPENDIX B}

(Reproduced from West Africa by the courtesy of the Editor.)

\section{THE LATE W. B. THOMSON}

\section{AN APPREGIATION BY A COLLEAGUE.}

IN connection with the death at sea of $\mathrm{Mr}$. W. B. Thomson, concerning whom an obituary article appeared in West Africa for February 2nd, "Langa Langa" writes to us from the Northern Provinces, Nigeria :-

"It is no posthumous sycophancy but unchallenged truth to say that with the tragic passing of W. B. Thomson the Political Service has lost one of its soundest and most capable officers, and his devotees (I can think of no other term) a friend who can never be replaced. Appointed in 1905, he quickly worked his way up to the position of Second-class Resident, and never was accelerated progress less grudged or better deserved.

"His entire period of service was spent in Bornu, where he became the idol of a coterie of friends of all tastes and temperaments, linked to him and each other by a freemasonry peculiar to that province-probably engendered in the first instance and consolidated by a common loyalty 
to the 'Ubangiji' of Bornu, Mr. W. P. Hewby, C.M.G. No easy task lay before him when he was called upon, as Resident of Bornu, to follow in the footsteps of such men as the last-named and Major Mclintock, D.S.O.; yet there was no one to whom those two would have more confidently handed over the interests of Bornu. An immediate comment on his ability to carry out this trust was forthcoming in his solution of the appalling famine difficulties of 1913-14, when rain fell twice in eighteen months; and later in his tactful handling of British and French interests, alternately with Captain Ruxton, during the Cameroon fighting. Von Raben's heartbroken words, as he (ipse ultimus) quitted for ever the last outpost of German West Africa, were a handsome testimony to the men of whom 'Tamsie' was so true a type.

"As a junior officer he was responsible for the evolution of the present form of assessment in Bornu, and a number of other lasting pieces of work bear the hall-mark of 'W.B.T.'; while, as a superior, his sympathy, his grasp of 'the things that mattered' (a rare qualification among high officials these days), and his good-natured, cynical Scottish humour made it a joy to work under him. Quite well known in the literary world, both as a writer himself and as a reviewer of the work of others, he had a particular penchant for Thomas Hardy, Balzac, and the Latin poets. Somebody with a superficial acquaintance once observed to me: 'Rather a bookworm, isn't he?' I should have dearly liked 
to put this naïve individual on a horse and invite him to race 'Tamsie' over hurdles, or ride him off on the polo ground. He would have been enlightened, for at these things the latter could hold his own with the best.

"And now, by a chain of chances, beginning with a bite from a rabies-suspected dog, which foreshortened his tour, and ending with a number of extensions which lengthened his leave, it was ordained that he should travel by a ship doomed to vanish from human ken in the night watches, leaving no soul alive to tell the tale. God rest him on ocean's bed, and comfort his mother and brave little wife, with whom only eight months ago he was enjoying his honeymoon! If it is glorious to die fighting the common enemy, it is at least not inglorious to die leaving no private enemy behind, as 'Tamsie' assuredly did.

"His numerous friends are already seeing to it that his memory shall be perpetuated in some lasting form, as was that of his predecessor, 'Maidoronyaki'; and may those two brave spirits protect and inspire the Bornu folk, both black and white, who loved them so well. Dignum laude virum musa vetat mori!" 


\section{APPENDIX C}

(Reproduced from West Africa by the courtesy of the Editor.)

\section{THE LATE PHILIP ASKELL BENTON}

IT seems only the other day that I wrote in these columns a-very inadequate-appreciation of the late W. B. Thomson.

And now again $I$ take up a sorrowful pen in the endeavour to do what little justice I may (there is little enough official recognition of these sterling men and their labours during their lifetime) to the memory of Philip Askell Benton, who succumbed on October 31st to that grim epidemic which has swept the country from Lagos to Lake Chad, and who was buried on November 1st at Ilorin, where he died. Under the devoted and ceaseless care of Dr. Stephens he had made a brave fight for a fortnight; but, having been a martyr to asthma for some twenty-four years, and of slender constitution, he never stood any real chance.

Following as it does so swiftly on the tragic death of "Tamsie," his intimate friend, the loss of Benton is one which the Service generally, and the already depleted Bornu "family" in particular can ill afford.

Affectionately known as " $\mathrm{Pa}$ " Benton by his very, very many friends, he was the most 
honourable and unselfish man I ever knew. If generosity can be measured in terms of money his material acknowledgment of the services of the steward who assisted him from the s.s. Karina when she was torpedoed, is striking enough example. As for his cross in life-asthmawhich used sometimes to lay him low for months at a time, sometimes suddenly, as it were, to strike him prostrate, I have never heard him so much as murmur. It is few people who, compelled, as he was, to pass their nights for over twenty years propped on their backs at an angle at which the ordinary man sits, would not have raised their voice in bitterness at their Creator.

Educated at Epsom College, and Corpus Christi College, Oxford, Benton joined the Political Service late in 1905; and it was only last August that his promotion to First-Class District Officer was gazetted.

Nearly the whole of his twelve years' service had been spent in his beloved Bornu Province, where he devoted himself to an exhaustive study of the history, people, and language of those parts. We have seen the result of some of this research in his Notes on Some Languages of the Western Sudan, The Sultanate of Bornu, Kanuri Readings, and A Bornu Almanac. And I am right, I think, in saying that another little work of his, with the proofs of which I had the privilege of assisting him, is at this moment in the hands of his publishers, Messrs. Humphrey Milford, Oxford University Press, 
It is characteristic of his generous nature that he intended to devote the proceeds of sale of his last work to the Red Cross Fund. His many friends will therefore have the opportunity, with every copy purchased, not only of supporting the finest cause in the world, but at the same time of paying a tribute to the memory of a man who never "played to the gallery," but quietly, for twelve years, officially and socially, gave of his best to the country which he loved, and which has at last claimed him.

LANGA LANGA.

\section{IBADAN,}

November 1918. 
$14^{\circ}$ 




\title{
PROVISIONS AND EQUIPMENT
}

Every Possible Kind of GROCERIES, PROVISIONS, WINES, SPIRITS

\author{
Also \\ MEDICAL STORES \\ of the Highest Qualities.
}

Complete Outfits and Equipment of Every Description for Residents in the Tropics.

"CHOP BOXES" a Speciality.

\section{GRIFFITHS, MCALISTER \& Co.}

29 \& 31, Manesty's Lane, LIVERPOOL

London Showroom:-

10, WARWICK STREET, REGENT STREET, LONDON, W. 1.

Telephone-REGENT 2159.

EsTABLISHED 1880. 


\section{Family and Colonial}

Bootmaker.

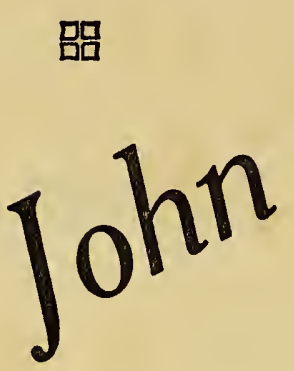

\section{.}

POLO BOOTS

FIELD BOOTS

SHOOTING BOOTS

MOSQUITO BOOTS

BROGUES

TENNIS SHOES

Carriage Paid to all parts of the World.

114 \& 115, BROAD STREET, READING, ENGLAND. 


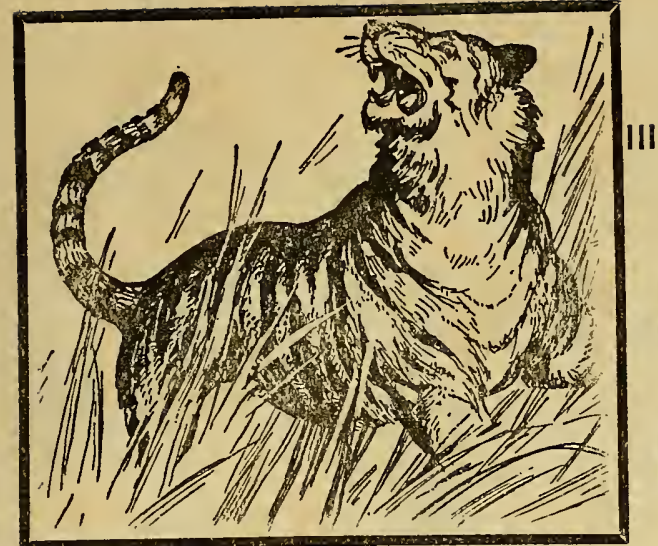

\section{IIIIIIIIIIIIIIIIIIIIIIIIIIIIIIIIIII \\ The}

Game

Killer.

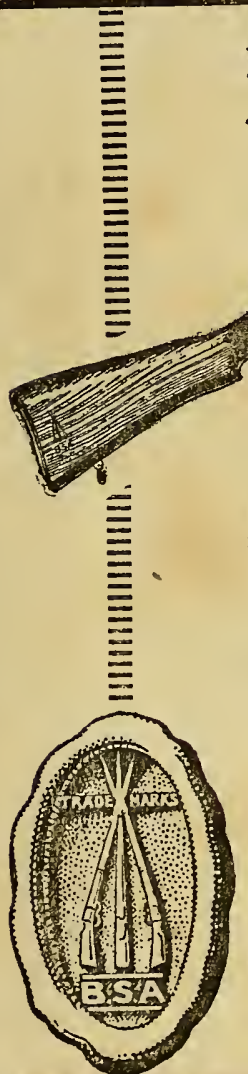

\section{B.S.A. Sporting Rifles.}

$\cdot 303 \& \cdot 315(8 \mathrm{~m} / \mathrm{m})$ bores.

shooting medium and soft-skinned game. They are manufactured from the finest materials, on the most up-to-date machinery and are strictly interchangeable. Cartridges for these rifles may be obtained in practically any part of the world.

Write now for further information, also particulars of the wonderful B.S.A. 12-Bore Hammerless Double Shot Guns, B.S.A. Air Rifles, 22 Match and Sporting Rifles and Accessories.

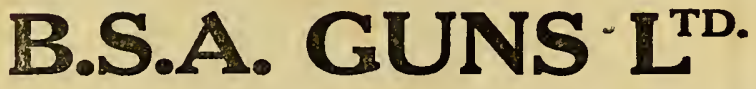
BIRMINGHAM - - ENGLAND Proprietors : THE BIRMINGHAM SMALL ARMS CO. LTD. 


\section{A ReAL DRINK}

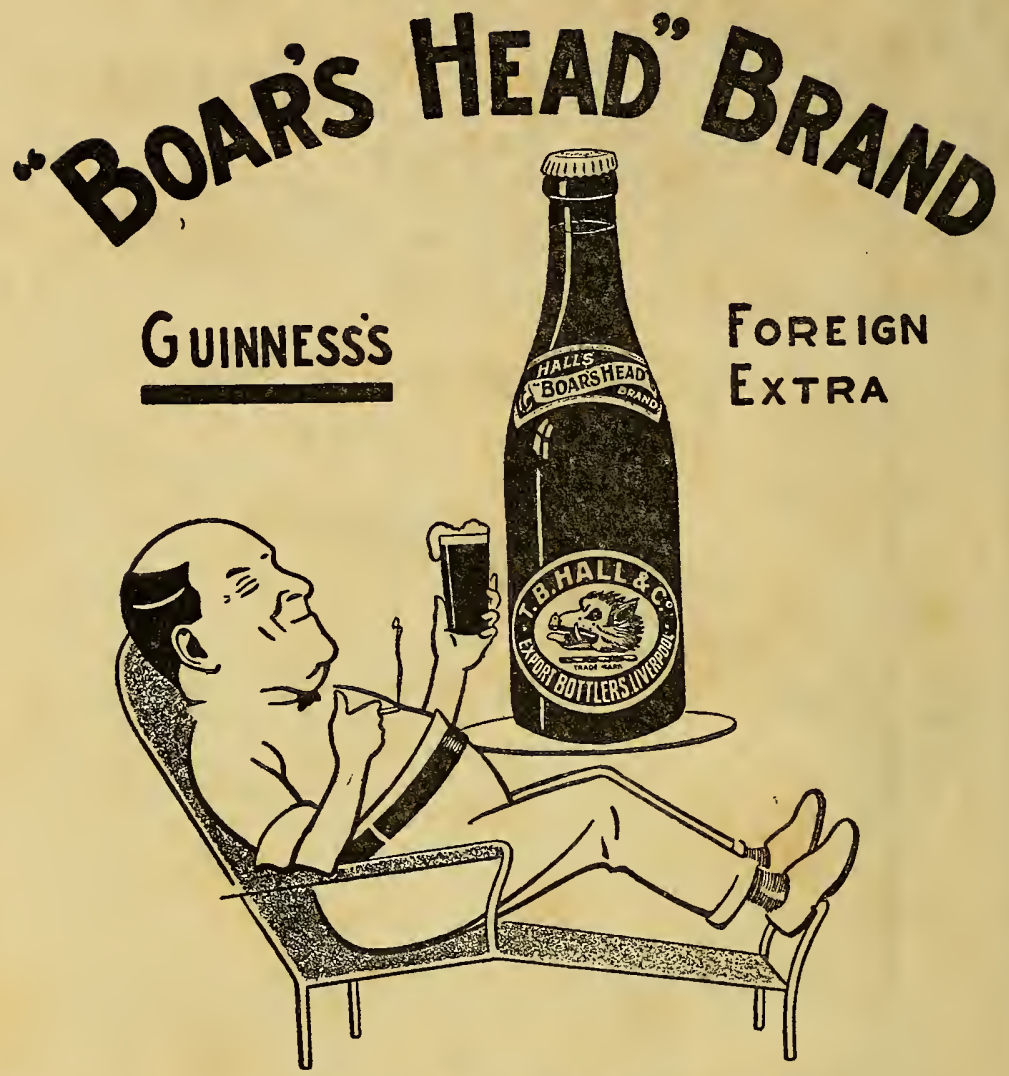

INDENTS THROUGH MERCHANTS ONLY

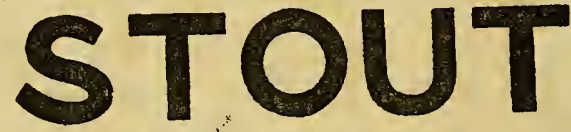

T. B. HALL \& C. LI. 75/63 Norfolk S: LIVERPOOL. 





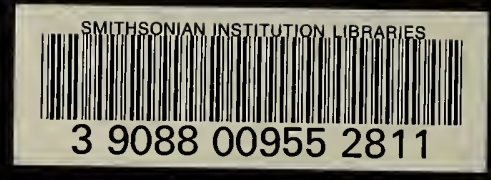

